Claremont Colleges

Scholarship@ Claremont

CGU Theses \& Dissertations

CGU Student Scholarship

1984

\title{
The Death of the Flying Wing : The Real Reasons Behind the 1949 Cancellation of Northrop Aircraft's RB-49
}

Francis J. Baker

Claremont Graduate University

\section{Recommended Citation}

Baker, Francis J., "The Death of the Flying Wing : The Real Reasons Behind the 1949 Cancellation of Northrop Aircraft's RB-49" (1984). CGU Theses \& Dissertations. Paper 74.

http://scholarship.claremont.edu/cgu_etd/74

DOI: $10.5642 / \operatorname{cguetd} / 74$

This Open Access Dissertation is brought to you for free and open access by the CGU Student Scholarship at Scholarship @ Claremont. It has been accepted for inclusion in CGU Theses \& Dissertations by an authorized administrator of Scholarship @ Claremont. For more information, please contact scholarship@cuc.claremont.edu. 
(C) 1984

FRANCIS JOSEPH BAKER

All Rights Reserved 
ABSTRACT OF THE DISSERTATION

THE DEATH OF THE FLYING WING: THE REAL REASONS BEHIND THE 1949 CANCELLATION OF

NORTHROP AIRCRAFT'S RB-49

By

Francis J. Baker

Claremont Graduate School: 1984

In an interview aired over the Public Broadcasting System in 1980, aircraft manufacturer John $\mathrm{K}$. Northrop made a stunning charge. Referring to the Air Force's 1949 cancellation of his Flying Wing aircraft, Mr. Northrop alleged that the cancellation was not the result of any valid concerns about the aircraft itself, but rather was a retaliation for his refusal to agree to an improper demand by the Air Force. Specifically, Mr. Northrop charged that then-Secretary of the Air Force stuart symington ordered him to merge his firm with Consolidated-Vultee Aircraft Corporation, and that when he refused, an 88 million dollar contract for the Flying Wings was cancelled. Mr. Northrop also admitted that in 1949 testimony before the House Armed 
Services Committee, he had perjured himself by denying that Mr. Symington had ever threatened or retaliated against Northrop Aircraft, Incorporated.

This dissertation began as a study of ethics and decision-making in the military procurement process. However, in-depth research revealed no improprieties in the Air Force's Flying Wing acquisition program. Research techniques included careful study of voluminous Air Force records, most housed at Edwards Air Force Base, California, and at the Air Force Historical Research Center in Montgomery, Alabama. These documents, once secret but now declassified, showed that military decision-makers were never satisfied with the Northrop plane, and regularly made their position clear to Northrop. The author's document searches were augmented by a series of interviews held with as many of the surviving participants as possible: Senator Symington, who vehemently denied any impropriety; Gen. Curtis E. LeMay, then Commander of the Strategic Air Command (SAC), who readily admitted that he never wanted the Northrop plane and argued against it (and for the competing B-36 bomber) before a board of senior Air Force officers just before the cancellation; Gen. Lauris 0 . Norstad, the sole surviving member of that senior officer's board, who vigorously rejected any suggestion of improper behavior by Senator symington in this or any other procurement decision. An interview with the current chairman of the Board of Northrop Corporation, Thomas V. Jones, generally supported 
Senator symington, and clarified the stand of today's Northrop management. In addition, the author interviewed and corresponded with the two Air Force chief test pilots on the Flying wing; both men gave valuable insights into the technical performance of the Northrop aircraft.

If political manipulation was not the cause of the 1949 cancellation, what was? The research uncovered four factors that were involved. First was the substantial improvement in the competing B-36, which made great strides in late 1948. Second was the assignment of General LeMay as SAC commander in October 1948; unlike his predecessor, General LeMay was a strong backer of the B-36, and was willing to give up other weapon systems (like the Flying wings) to get more of the Consolidated-Vultee B-36s. Third was President Truman's cuts in the Fiscal Year 1950 defense budget, which caused the Air Force to not only defer the addition of eleven planned combat units, but also to eliminate eleven others (of a total of fifty-nine) already in existence. Finally, the shortcomings of the flying wing were certainly numerous and significant enough to argue against its production and procurement.

After refuting a number of the allegations made in the 1980 broadcast, the dissertation concludes with some implications for management. Chief among these is the need to maintain a marketing orientation, that is, the requirement to emphasize what the customer requires, rather than what the producer wants to build. The Flying Wing was Mr. 
Northrop's lifelong dream, and the author argues that its production was more related to what Mr. Northrop wanted to build than to what the Air Force needed to acquire. 
THE DEATH OF THE FLYING WING: THE REAL REASONS

\title{
BEHIND THE 1949 CANCELLATION OF
}

NORTHROP AIRCRAFT'S RB-49

\section{By}

\author{
FRANCIS J. BAKER
}

A Dissertation submitted to the Faculty of Claremont Graduate School in partial fulfillment of the requirements for the degree of Doctor of Philosophy in the Graduate Faculty of Executive Management.

Claremont

1984 


\section{ACKNOWLEDGEMENTS}

A number of people cooperated in making this work possible, and I would like to acknowledge their contributions. Senator stuart symington offered a unique perspective, although he was not always certain of the direction the research would take, especially in its earliest stages. On some occasions--especially when I asked necessary questions about the actions and character of senior Air Force leaders like the late Generals Vandenberg and McNarney--I believe that he thought my queries impertinent. He was always patient, though, and his inputs proved essential to the dissertation.

Gen. Curtis E. Lemay was equally helpful, providing a view of the Strategic Air Command of the $1940 \mathrm{~s}$ as only he could. To a junior staff officer serving (at the time) in the Strategic Air Command, interviewing General LeMay could have been a most unnerving experience. He made sure that it was not, for which I was, and am still, extremely grateful. The Air Force's Flying Wing test pilots, General Robert Cardenas and Colonel Russ Schleeh, were both pleasures to work with. Both were candid in their comments, and straight-forward in their approaches. Whether it was General Cardenas explaining how he'd "been hounded and badgered" by writers like me for over thirty years, or Russ Schleeh casually mentioning how he'd done the hair-raising 
stalls in the YB-49 (". . just one or two to satisfy my curiosity"), the pilots were always refreshing and stimulating. In addition, Russ schleeh was an important source of encouragement throughout the life of this project.

My colleagues and friends in the United States Air Force Academy's Department of Management deserve special mention. Colonel Jim Woody and Majors Chuck Yoos and Bob Pizzi were constant sources of encouragement. They all knew more about dissertations than I did, and were valuable sounding boards for my ideas and concerns.

I'm especially grateful to my dissertation committee. They knew when to applaud my progress, and when to demand more. John Rae's special knowledge of the history of American business, particularly the American aviation industry, was invaluable. Similarly, Harvey Wichman's understanding of both aviation and psychology was an exceptionally helpful combination. Chairman David Drew has an unusual grasp of how government agents and agencies behave, and he was able to impart some measure of that understanding to me.

Finally, I offer my special thanks to my wife, Diane Baker. She encouraged me through the years of my doctoral study, and particularly throughout this dissertation. She typed the entire manuscript, but more importantly, was an essential advisor and confidante. Diane helped me through the dissertation's difficult times, and congratulated me when things went well. It is to her that this dissertation is dedicated. 


\section{PREFACE}

The reader will soon notice that the perspective of this dissertation tends to be an Air Force one. The viewpoint of the Northrop participants has been extensively reported, not only in the 1980 interview of Mr. Northrop and his associates, but in other forums as well. This dissertation will cite the numerous books and articles that have been written about the Flying Wings: most are unabashedly pro-Northrop, and do not present the Air Force side of the controversy. Likewise, some of the participants, most notably Mr. Northrop and his test pilot Max Stanley, have actively spoken out on behalf of Mr. Northrop's position: those speeches have not always looked objectively at all facets of the Flying wing program.

By contrast, the Air Force viewpoint has been largely ignored. This dissertation is an attempt to uncover those previously overlooked perspectives, through a scientific study of the available evidence. Previously classified Air Force documents tell of the many serious concerns which motivated the military decision-makers. Interviews with many of the surviving Air Force leaders, and with both of the Air Force's Flying Wing test pilots, provide corroborating evidence. In addition, comments by current Northrop Corporation management lend support to the dissertation's 
conclusions. The combination of these sources provides a complete history of the Flying Wing program. 
TABLE OF CONTENTS

ACKNOWLEDGEMENTS . . . . . . . . . . . . . . . . vii

PREFACE . . . . . . . . . . . . . . . . . . . $1 x$

INTRODUCTION . . . . . . . . . . . . . . . . . . 1

Chapter

I. THE CHARGE . . . . . . . . . . . . . . . . 4

II. BACKGROUND AND REVIEW OF DOCUMENTS: 1928-1944 . 11

III. BACKGROUND AND REVIEW OF DOCUMENTS: THE XB-35 IN THE POST-WAR YEARS . . . . . . . . . . . 27

IV. THE YB-49: THE FLYING WING BOMBER IN THE JET AGE . . . . . . . . . . . . . . . . 34

V. THE RECONNAISSANCE VERSION OF THE FLYING WING: THE YRB-49 . . . . . . . . . . . . . 52

Vi. CANCELlation OF the RB-49 PROGRAM . . . . . . . 67

VII. RESPONSES TO MR. NORTHROP'S STATEMENT: SENIOR AIR FORCE LEADERSHIP AND CURRENT NORTHROP MANAGEMENT . . . . . . . . . . . . . . 81

VIII. TECHNICAL PERFORMANCE OF THE FLYING WINGS: THE AIR FORCE PERSPECTIVE . . . . . . . . . . 102

IX. "THE FLYING WING--WHAT HAPPENED TO IT?": A CRITICAL REVIEW . . . . . . . . . . . 116

X. IMPLICATIONS FOR MANAGEMENT . . . . . . . . 129 BIBLIOGRAPHY . . . . . . . . . . . . . . 144 


\section{INTRODUCTION}

December of 1980 saw the airing of an interview over the Public Broadcasting system which reopened a controversy which had been dormant for thirty years. In the interview, John Knudsen Northrop, an aircraft designer and manufacturer, charged that his successful "Flying wing" aircraft design had been cancelled in retaliation for his refusal to knuckle under to demands by the secretary of the Air Force that he merge his firm with a larger, more favored aviation conglomerate. For some in the aviation industry, the interview merely confirmed long-held beliefs; others saw it as a shocking revelation about governmental power plays; a few thought it was a one-sided, biased slam at a distinguished public servant, who in his career was the first Secretary of the Air Force, a United States Senator, and even, for a while, a candidate for the Democratic presidential nomination in 1960 .

This dissertation started as a study of ethics in managerial decision-making, a study of a weapon system acquisition gone awry, a good aircraft design abruptly terminated by a political power play. The cancellation had long term effects: for example, NASA recently confirmed the design as an efficient one for a cargo transport, and the shape is also the basis for the highly-classified "stealth" 
aircraft, expected to be invisible to radar.

Some dissertation studies take unexpected turns as the research unfolds, and this is one of them. My research has shown that the cancellation of the Northrop Flying Wing was neither arbitrary nor political, but based on a number of valid considerations. In addition, there was one man who-perhaps more than any other-- was responsible for the choice of the Convair B-36 bomber, and the resulting cancellation of the Northrop Flying wing. But he was not the man accused by Mr. Northrop; instead, he was the man who was then the Commander of the Strategic Air Command, and who would have had to use whichever bomber was selected. The results of extensive interviews with him and others involved in the decision were among the considerations which led me to alter my original ideas.

If political chicanery was not to blame for the death of the Flying Wings, what was? The answer can be found in the lessons of marketing. We will see that such basic marketing precepts as the need to focus on the customer, emphasize product utility, and be aware of buyer behavior, never seemed to enter the realm of Northrop's selling efforts. Rather than being guided by what the customer needed, Northrop focused on the product it wanted to produce, and then tried to push that product on an unwilling buyer.

An unusual topic, fraught with charges and countercharges, with some participants no longer alive and events 
covering thirty years and more, requires an unusual format. In the first chapter I will recount, in some detail, the charges made by Mr. John K. Northrop, and corroborated by his Chairman of the Board, Mr. Richard W. Millar. In the next several chapters, I will discuss the history of the Flying Wing programs, and also the relationship of those programs to the competing B-36. Following chapters will deal with what I believe will show to be the real reasons for the cancellation. Finally, after a chapter which counters many of the claims made in the Public Broadcasting System documentary, I will conclude with implications for management and marketing derived from the Flying wing experience. 


\section{CHAPTER I}

\section{THE CHARGE}

In October of 1979, reporter Clete Roberts of the Public Broadcasting System station KCET-TV interviewed John K. Northrop, founder of Northrop Aircraft Corporation. Fourteen months later, after delays generated by the need to gather additional material and by a postponement request from Mr. Northrop, the interview was aired as a KCET documentary entitled "The Flying Wing--What Happened to It?" ${ }^{1}$ What Mr. Northrop had to say in the interview reopened what for many of those involved was an emotional issue that had remained dormant for more than thirty years. ${ }^{2}$

In the filmed interview, it was quite clear that the then 85-year-old Mr. Northrop was not in good health. His appearance was frail, his eyes watery, and his voice halting. But the viewer was left with the feeling that Mr. Northrop's mind was still sharp and his convictions strong, and he presented his case clearly and forcefully, as he told Mr. Roberts of the 1949 cancellation of his lifelong dream, the Flying Wing. Because of the significance of Mr. Northrop's charge, his statement deserves to be quoted at length: 
Well, it's a very strange story and perhaps difficult to believe, but it certainly is seared into my memory, and I'm quite sure I can give you the absolute facts as they occured.

The same day that Genȩral McNarney who was the chief--the military chief --of the Air Forces, came to my office with that additional order for thirtyfive airplanes, which he said was a drop in the bucket as far as the ultimate order was concerned, Mr. Millar and I were requested to visit Mr.

Symington. At that meeting, he lectured us rather lengthily on the difficulties of a secretary for Air in keeping things in hand, and told us that he did not want to sponsor any new aircraft companies entering the business and having to be supplied with business over the years, and that he wanted us without question to merge with Consolidated Vultee, which was then operating a government-owned plant in Fort Worth, building the $\mathrm{B}-36$, as a competitor to the B-35 or B-49 [Northrop's Flying Wing bombers].

After the lengthy diatribe on Mr. Symington's part, I said, "Mr. Secretary, what are the alternatives to this demand you're making of our merger with Consolidated Vultee?" He said, "Alternatives? You'll be goddamned sorry if you don't!"

General McNarney said, "Oh, Mr. Secretary, you don't mean that the way it sounds," and Mr. Symington said, "You're damned right I do!"

Well, this was a rather staggering termination of the meeting. . .

Interviewed for the same broadcast, Richard W. Millar, who in 1948 had been the Northrop Board Chairman, corroborated Mr. Northrop's story:

We were in effect directed to negotiate or work out a merger with Northrop and Convair. Jack Northrop asked the question, "What if we don't merge?" and Mr. Symington was quick to reply that we'd "be damned sorry if we didn't." We were told to get together with Mr. Odlum to work out a basis for the merger. I might say parenthetically that when Mr. Symington said in effect that we must do it, and we'd be sorry if we didn't, General McNarney spoke up and he said, as I recall, "Mr. Symington, you don't mean that, do you?" and Mr. Symington sajd in effect that, "Yes, you're damned right I do." 5

The merger allegedly demanded by Mr. Symington never came about. Mr. Northrop and Mr. Millar both indicated that 
they visited Floyd Odlum, then President of Convair's parent company, but that talks broke off because the two sides could not agree on terms. According to Mr. Northrop, it was shortly after the merger talks broke off that he received a telephone call from Mr. Symington:

I got a telephone call a few days later from Mr. Symington. He said, "I am cancelling all your Flying Wing aircraft." And I said, "Oh, Mr. Secretary, why?" And he said, "I've had an adverse report," and hung up. That was the last time I ever talked to him, and the last time we could ever reach him by phone or any other way.

Mr. Northrop went on to claim that the money which was to be used to purchase the Flying Wing then went instead to Convair, and was used to purchase more copies of the rival B-36.

MR. ROBERTS: Did he give the contract to someone else?

MR. NORTHROP: He continued the construction of the B-36 by Consolidated Vultee in Fort Worth.

MR. ROBERTS: So, in fact, the contract was taken from you, and given to Consolidated because you had refused to merge with consolidated, as you were ordered to do by the government, is that accurate? MR. NORTHROP: That is absolutely accurate. 7

The picture painted by Mr. Northrop, and corroborated by Mr. Millar, is one of a rash and seemingly corrupt decision, made all the more brutal by the way the judgment was handled. But if Mr. Northrop believed he was unfairly treated, why did he testify otherwise at a 1949 House Armed Services Committee investigation? When asked by Mr. Joseph Keenan, General Counsel to the Committee, whether Mr. Northrop believed there were political implications in the 
Flying Wing cancellations, he answered in a strong manner:

MR. NORTHROP: I believe there were none. I can't conceive of there being any.

MR. KEENAN: And you make that statement under oath before this committee?

MR. NORTHROP: I do, sir.

MR. KEENAN: Genuinely believing it?

MR. NORTHROP: I certainly do.

MR. KEENAN: And not because you are in fear of reprisals?

MR. NORTHROP: No sir, I am not in fear of reprisals.

But persistent rumors about forced mergers between

Convair and other manufacturers caused the Committee Counsel

to press further. A few minutes later, Mr. Northrop was questioned yet again by Mr. Keenan:

MR. KEENAN: Have you any knowledge that either yourself as president or any officer or anyone else connected with Northrop Corporation being informed [sic] that unless Northrop agreed to merge with Consolidated that business would be bad for Northrop?

MR. NORTHROP: I have no such knowledge.

MR. KEENAN: Has anyone ever said anything from which you could draw such an inference?

MR. NORTHROP: NO, sir.

MR. KEENAN: Specifically did Mr. Odlum ever say that? MR. NORTHROP: No, he did not.

MR. KEENAN: Or Mr. Symington?

MR. NORTHROP: NO, sir. ${ }^{9}$

So in 1979, thirty years after his dramatic 1949 testimony, Mr. Northrop changed his story, contradicting his 
sworn statements before the House Armed Services Committee. Mr. Roberts asked Mr. Northrop about his reaction to his 1949 testimony, in light of his 1979 reversal.

MR. NORTHROP: MY reaction is that, under pressure of the life or death of Northrop Corporation, I committed one of the finest jobs of perjury that I've ever heard.

MR. ROBERTS: You did not tell the truth.

MR. NORTHROP: I did not tell the truth.

MR. ROBERTS: And the reason for doing that was . .

MR. NORTHROP: The reason for doing that was fear of the Secretary--the Air Secretary, Mr. Symington-fear of his complete obliteration of Northrop Aircraft Corporation.

MR. ROBERTS: How does it happen, Mr. Northrop, that for thirty-one years this story has not been told?

MR. NORTHROP: The reason... is the same as the reason for my initial perjury, and it was the fear - . that any intimation of this circumstance would result in a complete cancellation and obliteration of the company.

Once again, Mr. Millar was able to corroborate Mr. Northrop's story:

- . the meeting with Mr. Symington was so, shall I say, brutal . . barefaced . . so obviously, if you will, a powerplay that you almost had to assume that he would be prepared to take further steps if we didn't go as good boys and go along. . . .

Mr. Roberts claimed that he tried to contact former Secretary symington, and offered him an opportunity to respond to the charges of Mr. Northrop and Mr. Millar. Mr. Roberts said that Secretary symington declined, saying only--through his secretary--that he "never did that sort of thing." 12

With General McNarney and Mr. Northrop now dead, Mr. 
Millar refusing any further comment, and senator symington silent until now, the reasons for the cancellation have remained a source of disagreement. Reporter clete Roberts acknowledged this in his emotionally charged conclusion:

The question might properly be asked, "How much has military aviation in America been set back by the destruction of the 'Flying Wings'?" One has the feeling that only the surface has been scratched in the story of the B-49 'Flying Wing'. The disturbing fact remains that a revolutionary aircraft design was apparently short-circuited in the development program of American aviation, a design that, in the words of NASA, has only recently been rediscovered, and might well represent the next form of large cargo aircraft. There are overtones of politics and big business power plays that appear to have affected the product of the genius of John Knudsen Northrop. The B-49--the iflying Wing'--now little more than a memory. . . .

\section{$\underline{\text { Summary }}$}

The charges were dramatic, and it appeared that $\mathrm{Mr}$. symington elected to refrain from a strong, on-camera refutation. But this dissertation will show that, for whatever reasons, Mr. Northrop's charges have the effect of trying to make a very complex situation overly simplistic, and the KCET documentary did not help to clarify the issue. There were unquestionably valid concerns which contributed to the cancellation of the Flying wing, not one of which was even mentioned in the KCET-TV interview. Later chapters will address each of those contributing concerns, but first it is necessary to cover the lengthy and complex history of the Northrop Flying Wing program. 


\section{Chapter I Footnotes}

${ }^{1}$ KCET-TV, "The Flying Wing--What Happened to It?," December 3, 1980 .

2 "Northrop Claims AF Scuttled 'Flying Wing'," Los Angeles Times, December 8, 1980.

3 Actually, General McNarney--who went on to become President of Convair after his retirement--was the Commander of the Air Force Materiel Command at that time. The "military chief of the Air Forces" was Gen. Hoyt S. Vandenberg, the second Air Force Chief of Staff.

4 "The Flying wing--What Happened to It?"

${ }^{5}$ Ibid.

${ }^{6}$ Ibid.

7 Ibid.

${ }^{8}$ U.S., Congress, House, Armed Services Committee, Investigation of the B-36 Bomber Program, Hearings on H.R. 234; 81st Congress, First Session, 1949, p. 274.

${ }^{9}$ Ibid., p. 284 .

10 "The Flying Wing--What Happened to It?"

${ }^{11}$ Ibid.

12 Ibid.

13 "Northrop Claims AF Scuttled 'Flying Wing'"

14 "The Flying Wing--What Happened to It?" 


\section{CHAPTER I I}

\section{BACKGROUND AND REVIEW OF DOCUMENTS: 1928-1944}

The Northrop Flying wing bombers did not suddenly burst forth, fully developed in the late 1940s. Rather, the Wings had their roots in developmental programs begun twenty years before, eventually growing from small, wooden test aircraft to the giant, eight-jet YB-49 that would awe the aviation industry just after the Second World War.

Like all developmental aircraft, the early Flying Wings suffered from their share of problems. It is significant, though, that unlike other programs in which the "bugs" are eventually corrected, the flaws affecting the Wings were most persistent. In fact, this chapter will highlight several problems plaguing the early Flying Wings, problems that caused cancellation of most of the B-35 bomber production program in 1944, and which would haunt the subsequent YB-49 effort in the Post-War years.

\section{Genesis}

The saga of the Northrop Flying Wings began in 1928, when his desire to experiment with radically new aircraft designs led John Knudsen Northrop to leave the Lockheed Aircraft Company, and to form his own corporation. His new firm--Avion Corporation of Burbank, California--began to 
experiment in a number of areas, including the study of allwing designs. This led to the fabrication of the very first Northrop Flying wing, which made its maiden flight at Burbank in 1929. ${ }^{1}$

This first Flying wing was not actually an all-wing aircraft, since stability requirements demanded that Northrop include two outrigger-type booms which connected to the tail control surfaces. Northrop explained that he saw the half-radical, half-conventional design as a necessary evil: "We didn't dare go the whole way and eliminate the tail." ${ }^{2}$ But, as with the giant wings which would follow in the next two decades, the crew compartment, engine, and fuel tanks were buried within the Wing's thirty-foot, sixinch span.

The prototype Flying Wing, identified as "X216H", made a number of flights in 1929 and 1930, most at Muroc Dry Lake, California. (Muroc would later be renamed Edwards Air Force Base, in honor of an Air Force test pilot killed in a 1948 crash of a Flying Wing bomber.) But while the $\mathrm{x} 216 \mathrm{H}$ program was a technical success, it was soon sidetracked by the Great Depression. ${ }^{3}$ United Aircraft and Transportation Corporation absorbed Northrop's Avion (renaming it Northrop Aircraft Corporation) in 1929, and by 1932 was pushing for a merger between Northrop and United's Stearman Aircraft subsidiary in Kansas. John Northrop balked at the idea of a merger, just as we will see that he did again sixteen years later, and broke with United, forming a new 
Northrop Corporation. But as before, Northrop was a small part of a larger enterprise; this time, the controlling force was Douglas Aircraft, which owned fifty-one percent of Northrop stock. 4

During the 1930s, Northrop developed a number of new aircraft designs. New Flying wing concepts were studied, but no new aircraft of the type were built. In 1938, Northrop's dependence on Douglas was underscored when his corporation was again renamed, this time changing from the Northrop Corporation to the El Segundo division of Douglas Aircraft. Within a year, Jack Northrop pulled out of Douglas Aircraft entirely, starting still another new firm: Northrop Aircraft, Incorporated. Total employment stood at six: Northrop himself was president, as well as head of engineering and research. ${ }^{5}$ But he was on his own--free to experiment and innovate, free to design his own aircraft rather than produce someone else's components. And one of the first designs to emerge was a new and more radical version of $\times 216 \mathrm{H}$ : the N-1M Flying wing.

\section{The $N-1 M$}

The N-1M (which stood for Northrop-Model 1 Mockup) 6 started life not on the drawing board of an aeronautical engineer, but in a completely different--and far less conventional--environment:

The N-1M . . Was built in wooden mockup form which made possible many changes in shape during the testing processes. One major problem was how to obtain directional stability, and how to get the effect of fins and vertical surfaces without actually having 
them protrude from the wing surface.

The answer took shape when Mr. and Mrs. Northrop

were guests of Moye Stephens, then the company's

secretary, at the latter's ranch home one rainy weekend. The group was unable to take a planned hike, because of the weather, so stayed indoors and experimented with paper airplanes.

These paper models at first were in the conventional schoolboy's pattern, but later were folded into shape much like that of the Flying Wing. Tips of the wings were bent up and down and with each change the paper planes were "flown". Soon it was found that a downward bend of thirty-five degrees gave the best performance. . . . This seeming child's play actually resulted in valuable ${ }_{7}$ data and, later at the plant, was put into practice.

Tests in the National Advisory Committee for Aeronautics wind tunnel confirmed the effectiveness of the drooped wingtips, and they were incorporated in the full-scale aircraft. 8

In May of 1940 , the completed $\mathrm{N}-1 \mathrm{M}$ was painted bright yellow, and then secretly trucked by night from Hawthorne to the Army Air Corps test base at Muroc. The first flight came two months later on July 3rd, and the exact circumstances of the flight are still somewhat in question. Official Northrop documents are in accord with this comment, made by company test pilot Max Stanley in 1980:

On July 3 rd, it accidentally made its first flight. The pilot, Vance Breese, while making a high speed taxi run, hit a rough spot on the lake bed. The airplane bounced about ten feet in the air, flew straight and level for a few hugdred yards, and then settled back onto the lake bed.

But another report tells a somewhat different story, a story which hints that perhaps not everyone fully shared Mr. Northrop's faith in his design:

. . the magazine Time reported that "it looked like a ruptured, weather-racked duck, too fatigued 
to tuck in its wings." Pilot Vance Breese tried taxying [sic] and then, on July 3, cautiously lifted off and held the yellow wing as close to the ground as he could--as someone said, "to make the crash a bit easier." Northrop's comment was, "It looks like 10 we have an airplane with a twenty-foot ceiling. . ."10

Whether the first flight of the $\mathrm{N}-1 \mathrm{M}$ was accidental or merely prudent, the aircraft went on to complete an extremely successful flight test program. There were no serious accidents, and, with the exception of engine cooling problems, no major technological difficulties. In more than two hundred flights, pilots Breese and Moye Stephens explored the whole design envelope of the $\mathrm{N}-1 \mathrm{M}$, including stalls and spins, and in so doing proved the Flying wing to be a valuable and promising design. 11

\section{The First Flying Wing Bombers: The $\mathrm{XB}-35$}

With the all-wing principle validated by the successful test program of the N-1M, Jack Northrop turned his attention to larger aircraft. On May 21, 1941, he wrote a Confidential letter to Col. Howard $\mathrm{Z}$. Bogert of the Army Air Corps Materiel Division at Wright Field. In the letter, Mr. Northrop first raised the prospect of a large Flying Wing bomber:

- . we have made very successful and encouraging flights of the flying mockup (N-1M) and I believe the time is here when we can seriously cphsider building bomber aircraft to this design.

Just two days later, Mr. Northrop again wrote to Colonel Bogert, saying that the performance specifications had been clarified by a visit from Brig. Gen. Oliver P. Echols, Commander of the Air Materiel Command: 
General Echols indicated that a high speed of 400 $\mathrm{mph}$ and $\mathrm{a}$ bomb load of 5,000 pounds was what was desired, with all additional performance we might be able to obtain to be devoted to increasing the range of the airplane. . . We believe we could carry between 10,000 and 15,000 pounds of bombs for 5,000 miles. . . However, we have made no accurate range studies whatsoever as yet, $\mathrm{so}_{3} \mathrm{I}$ would not want to be quoted on the above figures.

Just four days later, the Air Corps formally solicited a design study from Northrop for a Flying Wing bomber capable of the following performance levels: ${ }^{14}$

$\begin{array}{lrr} & \text { Minimum } & \text { Desired } \\ \text { Range (miles) } & 5,333 & 6,000 \\ \text { Maximum Speed (mph) } & 400 & 450 \\ \text { Average Speed (mph) } & 250 & 300 \\ \text { Ceiling (feet) } & 35,000 & 45,000\end{array}$

On September 12, 1941, Mr. Northrop responded, offering to sell the Air Corps one Flying wing bomber (by now designated the $\mathrm{XB}-35)$ for $\$ 2,870,000$. He said a second could be built for $\$ 1,550,000$. The first aircraft could be completed within twenty-four months of contract approval; delivery of the second could be negotiated later. ${ }^{15}$

On November 1, 1941, a contract was formalized, with Northrop providing one XB-35 bomber, plus a wooden mockup and flight data information, for a total price of $\$ 2,910,000 .^{16}$ But almost immediately, problems arose. Northrop had never built an aircraft the size of the $\mathrm{XB}-35$, and on December 1, 1941, the corporation notified the Assistant Chief of the Materiel Division that they were facing a serious capacity problem. While a second $\mathrm{xB}-35$ 
could be assembled within five months of the first, space constraints at the Hawthorne plant were such that there could be no assembly line. In fact, there was not even room to assemble a single $\mathrm{XB}-35$, unless Northrop went ahead and built a new structure for that purpose. Even that proposed building would only handle one bomber at a time: assembly of subsequent aircraft could not begin until the previous one was complete. ${ }^{17}$ This proved to be a crucial problem: similar space constraints would plague Northrop throughout the decade, and would prove to be one of the factors which ultimately contributed to the Flying Wing's demise.

Just six days later, though, the Japanese attack on Pearl Harbor gave new impetus to the Flying Wing program. On December 12, the Air Corps ordered the second XB-35. ${ }^{18}$ Six months later, the wooden mockup of the XB-35 was ready for review by the Air Corps Experimental Engineering Section; because it was so revolutionary and so highly classified, British members assigned to the American team were not allowed to take part in the inspection of the mockup. ${ }^{19}$

But by later in 1942, the XB-35--like other projects-was tangled in a confusing web of national priorities. Shortages of resources--especially engineering talent--were threatening to cause long delays in a number of aircraft programs. Attempts were made to get increased resources applied to the $\mathrm{xB}-35$ effort, thus freeing the $\mathrm{xB}-35$ from this entanglement, but the efforts were unsuccessful. On September 28, 1942, the Deputy Chief of the Air Staff wrote 
to the Commanding General of Materiel Command, General Echols :

Highest priority should be given research and development activities for these particular projects [XB-35, and Convair's competitor XB-36] by the Air Corps, with particular reference to Northrup [sic] engineering personnel. . . An attempt should be make to secure AAA priority from W. BOB. [War Production Board] for these airplanes.

The Commander of Materiel Command responded, describing the hectic wartime environment, in which the shortage of men and materiel contributed to the long delays that would prove characteristic of both the $\mathrm{XB}-35$ and $\mathrm{XB}-36$ programs:

The very highest priority possible has been given to the Northrup [sic] XB-35. . . Efforts have been made and are still being made . . . to borrow engineers from other manufacturers on the West coast to assist Mr. Northrup [sic]. To date no success has been had. . . . There is a definite shortage of engineers in the industry and in the Materiel Command. Practically all projects have extremely high priority. Whenever an endeavor is made to expedite any project, it results i $\eta_{1}$ delay of some other project of highest priority.

By November, though, help was on the way. The Air Corps decided to cancel a contract with the Glenn Martin Company for design and production of 402 B-33 bombers. The Air Staff directed thet "the B-33 will be abandoned immediately and the engineering talent engaged thereon will be transferred to the $\mathrm{xB}-35$ and $\mathrm{xB}-36$ projects." 22

But General Echols of Materiel Command was aware that the engineering shortage was only part of Northrop's problem. He understood all too well that even with the transfer of Martin's engineers to Northrop, the space constraints at Hawthorne still would make mass production 
infeasible. Therefore, General Echols decided to give Martin the right to build the Flying wing bombers, by converting Martin's B-33 contract to $\mathrm{YB}-35 \mathrm{~s}$. In a note added to the Confidential Air Staff memo abandoning the B-33, General Echols wrote:

I have issued instructions to Wright Field... to start procedure to convert B-33 contracts to B-35. I have taken this matter up with Mr. Martin personally and his representatives are now at the Northrop plant in Calif.

$$
\text { O.P.E. }{ }^{23}
$$

The theme of this memo from General Echols is central to the whole Flying Wing story: because Northrop did not have the capacity for quantity assembly, the Air Corps had to turn elsewhere for the actual production runs. In this case, the beneficiary was the Glenn Martin Company. Six years later, the situation would arise again, with Convair taking on production of the $\mathrm{xB}-35^{\prime}$ 's successor, the jet-powered RB-49. In both cases, the underlying cause was the same: Northrop was simply incapable of producing the Flying Wing bombers in the quantities required.

Five days after the General Echols memo, the Air Corps notified Northrop that the B-35 would be built by Martin at its Baltimore plant. ${ }^{24}$ By December, 1942, Materiel Command had decided the specifics: Northrop could build one hundred B-35s at Hawthorne, while Martin built another hundred at Baltimore. ${ }^{25}$ But even the hundred $B-35$ s were too much for Northrop. On December 28, 1942, General Echols was informed that Northrop did not want to participate in any production beyond the experimental and service test 
craft:

Northrop has been contacted and indicates that with their facilities as now existing, they will be unable to fabricate more than the XB [experimental] and YB [service test] type airplanes already on contract, and asked that they be relieved of the ${ }_{6}$ load of fabricating these additional one hundred.

The entire order of two hundred B-35s was then shifted to Martin, which was able to promise an eventual delivery rate of forty aircraft per month. 27 But the joint venture between Northrop and Martin proved ineffective. By May 1943, Martin halved the projected peak delivery rate to twenty planes per month, and acknowledged that even that rate could not be reached until september $1945 .^{28}$ other problems being faced by Martin were brought to the attention of Materiel Command. On May 18, 1943, Martin told the Commanding General of Materiel Command about Northrop-directed changes in the $\mathrm{xB}-35^{\prime} \mathrm{s}$ aluminum skin: "We wish to bring out this information in order that you may fully realize the unknowns that we are facing in the manufacture of this airplane." 29 More months of bickering between Martin and Northrop followed, until in August 1943 Martin notified Air Materiel Command that it wanted to be released from the $\mathrm{B}-35$ project :

Due to the uncertainties surrounding this project and due to the existing doubts as to whether the airplane is now ready for production, it seems improper to incur fyrther production expenditures at this time. . .

In the meantime, a one-third scale model Flying wing-called the N-9M--was undergoing wind tunnel and flight testing, and the disappointing results had reached Washington. 
Chief of Army Air Forces General H.H. "Hap" Arnold wired the Commanding General of Materiel Command on November 24, 1943:

Latest information indicates that the $\mathrm{xB}-35$ range has dropped off 1600 miles, and high speed has dropped twenty-four miles below previous estimates. Detailed information is desired, especially insofar as range is concerned. . . . In view of this latest disappointment [,] request you present opinion as to the merits of the $\mathrm{XB}-35$ and the desirability of 3 continuing the present extensive production plans.

By early 1944, the entire XB-35 program was in serious trouble. Northrop couldn't produce the aircraft in quantity, the Martin Company was unhappy in its role as producer of another firm's design, and the entire project was far behind schedule. The $\mathrm{xB}-35$ was still years away from its first flight, and now data based on its flying scale model N-9M showed that performance would be far below expectations. In August of 1941, the Materiel Command had nearly doubled the required range of the $\mathrm{xB}-35$ to ten thousand miles. But in January 1944, a Materiel Command memo estimated the $\mathrm{XB}-35^{\prime} \mathrm{s}$ range with a ten-thousand-pound bomb load at only 5200 miles. While this was a significant improvement over the then-operational B-29, it fell far short of the Army Air Force's requirements. 32

There were still other problems. One of the N-9M flying scale models had crashed in May 1943, killing the pilot, and subsequent investigation pointed toward dangerous and mysterious handling characteristics at low speeds. 33 Then the Martin Company--brought in to bring engineering help to the project--itself became short of engineers, and had to borrow 350 draftsmen from the otis Elevator company. 
Martin estimated that this would delay the first B-35 delivery until at least $1947 .^{34}$ Soon thereafter, Martin lost even more engineers to the selective service draft. Finally, in an undated, handwritten memo, General Echols, by that time Assistant Chief of the Air Staff, officially killed the production aspect of the program with which he had struggled for so long:

Prepare a memo to Chief of Air Staff recommending that due to the additional delay. . 3 we cancel the production contract with Martin. . .

In 1941, Northrop had said that the first XB-35 could be delivered in November of 1943, i.e., twenty-four months after the contract was signed. ${ }^{36}$ But by May 1944, the best estimate for the $\mathrm{XB}-35^{\prime} \mathrm{s}$ maiden flight was August 1945,37 and Martin couldn't deliver the first production B-35s until $1947 .{ }^{38}$ while much of the problem was beyond the control of either Northrop or Martin, the combination of long delays and changing wartime requirements led the Air Staff to agree that at least the production contract for two hundred $\mathrm{B}-35 \mathrm{~s}$ should be terminated. On June 3 , 1944, a terse letter from a low-ranking contracting officer to the Martin Company made it official:

The Government no longer requires the articles called for under subject contract and haşgtherefore terminated the same for its convenience.

Northrop was permitted to continue work on the two experimental (XB) and thirteen added service test (YB) models, but all plans for large scale production were scrapped. Those fifteen $X B$ and $Y B$ models, though, would form the core 
of the post-war Flying Wing bomber program, and would lead to perhaps the ultimate Flying wing: the eight-jet YB-49.

\section{$\underline{\text { Summary }}$}

In essence, the Flying Wing bomber programs can be classed in two eras. The first, running through all of World War II, was characterized by the development of the propeller-driven $\mathrm{XB}-35$. The second era began with the first $\mathrm{XB}-35 \mathrm{flight}$, and would continue through the test program of the jet-powered YB-49 and YRB-49.

We will see that both programs were unsuccessful, and for remarkably similar reasons. First, aircraft stability-in serious doubt after the 1943 crash of the $\mathrm{N}-9 \mathrm{M}--$ proved to be an equally significant problem in the post-war program. Second, Northrop's lack of plant capacity--the cause of the whole Martin Company involvement--proved equally crippling during the the YB-49/YRB-49 development. Finally, aircraft performance, especially range, was disappointing in the $\mathrm{XB}-35$, and would be far more troubling with the YB-49. These factors, all part of the cancellation of the B-35s, would play equally critical roles in the 1949 cancellation of the $\mathrm{RB}-49$. 


\section{Chapter II Footnotes}

${ }^{1}$ Fred Anderson, Northrop: An Aeronautical History (Los Angeles: Northrop Corporation, 1976), p. 2 .

2 "The Story of Jack Northrop and the Flying Wings," p. 3. The exact background of this document is unclear. From its tone and style it appears to have been a Northrop press release, undated but probably written in early 1949. The thirteen-page document was uncovered by the author during a search of the historical archives at Edwards Air Force Base in 1981.

${ }^{3}$ Ibid., p. 4. See also Anderson, Northrop: An Aeronautical History, p. 7.

${ }^{4}$ Anderson, Northrop: An Aeronautical History, p. 7. ${ }^{5}$ Ibid.

${ }^{6}$ Bill Gunston, "The All-Wing Northrops," Aeroplane Monthly, January 1974, p. 444 .

7 "The Story of Jack Northrop and the Flying Wings," pp. 4-5. The tale, perhaps apocryphal, is retold in Northrop: An Aeronautical History, p. 27.

8 Anderson, Northrop: An Aeronautical History, p. 27.

${ }^{9}$ Max Stanley, "The Flying Wings," contained in Society of Experimental Test Pilots, Twenty-Fourth Symposium Proceedings, (Beverly Hills, California: n.p., 1980), pp. 239240. The report contains the prepared text of Max Stanley's speech to the symposium.

${ }^{10}$ Gunston, "The All-Wing Northrops," p. 445.

${ }^{11}$ Ibid., pp. 445-446. See also Anderson, Northrop: An Aeronautical History, pp. 27-28.

12 John K. Northrop to Col. Howard Z. Bogert, Army Air Forces Materiel Command; May 21, 1941. Confidential letter contained in historical archives at Edwards Air Force Base.

13 John K. Northrop to Col. Howard Z. Bogert; May 23, 1941. This Confidential letter, as well as others referred to in this dissertation, is contained in "Case History of the XB-35 Airplane project," an undated collection of documents compiled in the 1940's by the Historical

office, Air Materiel Command, Wright Field, Ohio. Most of these documents were at one time classified either "Confidential" or "Secret"; all are now declassified. 
${ }^{14}$ Lt. Col. A.E. Jones to Northrop Aircraft, Incorporated; Confidential letter; May 27, 1941.

${ }^{15}$ John K. Northrop to Assistant Chief, Materiel Division, Wright Field; Confidential letter; September 12, 1941 .

${ }^{16}$ Contract No. W535 ac-21920, Project No. MX-140, November 1, 1941 .

17 John K. Northrop to Assistant Chief, Materiel Division; letter; December 1, 1941.

${ }^{18}$ Change order No. 1 to Contract No. W535 ac-21920, December 12,1941 .

${ }^{19}$ Internal Materiel Command memo, unsigned, to the Chief, Experimental Engineering Section; June 27, 1942.

${ }^{20}$ Brigadier General L.S. Kuter, Deputy Chief of the Air Staff, to Commanding General, Materiel Command; Confidential memo; September 28, 1942 .

${ }^{21}$ Major General O.P. Echols, Commanding General, Materiel Command, to Deputy Chief of the Air Staff; Confidential memo; September 30, 1942.

22 Brigadier General T.J. Hanley, Jr., Deputy Chief of the Air Staff, to Commanding General, Materiel Command; letter; November 9, 1942.

${ }^{23}$ Ibid., note added.

24 "Vanaman" to Western District Supervisor; telegram; November 14, 1942. Telegram instructed the Western District Supervisor to relay information to Northrop.

25 Brigadier General B.E. Meyers to Technical Executive, Wright Field; letter; December 1, 1942.

26 Technical Executive to Commanding General, AAF Materiel Command; telegram; December 28, 1942.

27 Technical Executive to Assistant Chief of Staff (P) ; telegram; February 25, 1943.

${ }^{28}$ Harry T. Rowland, Vice President, Glenn Martin Company, to Commanding General, AAF Materiel Command; Confidential letter; May 6, 1943.

${ }^{29}$ Harry T. Rowland, Vice President, Glenn Martin Company, to Commanding General, AAF Materiel Command; Confidential letter; May 15, 1943. 
${ }^{30}$ Harry T. Rowland, Vice President, Glenn Martin Company, to Commanding General, AAF Materiel Command; Confidential letter; August 11, 1943.

${ }^{31}$ General H.H. Arnold, Commanding General, Army Air Forces, to Commanding General and to the Technical Executive, AAF Materiel Command; telegram; November 24, 1943.

32 Brigadier General F.O. Carroll to Major General O.P. Echols, Commanding General, AAF Materiel Command; memo; January 10,1944 . While the originally specified minimum range was 5,333 miles (see footnote 14 above), that specification was increased to 10,000 miles on August 20, 1941, by a telephone call from then-Lt. Colonel Carroll to a representative of Northrop. See telephone transcript in Air Materiel Command files.

33 John K. Northrop, "Conclusions Concerning Crash of N9-M Airplane \#1," May 19, 1943. Mr. Northrop himself wrote the report, and while the tone is impassive and clinical, one still is left with the feeling that Northrop was discussing the death of a cherished dream. He closed the report with these words: ". . . it is believed that the plane may have dangerous spin characteristics which cannot be controlled by normal use of the control surfaces in their present configuration."

34 Brigadier General F.O. Carroll to Major General O.P. Echols, Commanding General, AAF Materiel Command; letter; February 17, 1944.

35 Major General O.P. Echols to Materiel Division, undated, memo number 3-7931AF.

${ }^{36}$ see footnotes 15,16 above.

37 Major General B.E. Meyers to Chief of the Air Staff; letter; May 6, 1944.

${ }^{38}$ see footnote 34 above.

${ }^{39}$ Capt. John A. Carr to Glenn Martin Company; letter; June 3, 1944. 
CHAPTER III

\section{BACKGROUND AND REVIEW OF DOCUMENTS \\ THE XB-35 IN THE POST-WAR YEARS}

Although the Army Air Force cancelled quantity production of the B-35s, work continued at Northrop on the limited number of experimental (XB) and service test (YB) airplanes. Finally, on June 25, 1946, the first XB-35 took to the air--nearly three years behind schedule ${ }^{1}$ and at a cost nearly five times the original estimate. ${ }^{2}$

\section{$\underline{\text { Flight Test }}$}

The first flight--from Northrop Field to Muroc--was uneventful, and largely trouble-free. ${ }^{3}$ But that was to be the first and last trouble-free flight for the $\mathrm{XB}-35$. For the rest of their existence, the XB- and YB-35s would be hampered by a seemingly endless succession of problems, most of which, ironically, were not directly associated with the Flying wing configuration itself.

The most critical and persistent problems with the XB-35 were related to the gearbox and propeller systems. Each of the four Pratt and Whitney $\mathrm{R}-4360$ engines drove two sets of four propeller blades, each set rotating in a different direction. Northrop test pilot Max stanley summed up the troubles in a 1980 speech: 
It was plagued with problems from the very beginning of the program. . propellers which would fail to govern, or would not feather, and if they did feather, they would not unfeather. The driveshaft would develop unacceptable vibration. The gearbox would overheat. Each of these malfunctions resulteg in program delays, some of which were extensive.

The $\mathrm{XB}-35^{\prime} \mathrm{s}$ problems were at least as serious as stanley's speech indicated, and perhaps more so. One of the first test flights ended with both engines on the same side shut down because of propeller failure, and for a time the $\mathrm{xB}-35$ was grounded while a solution was sought. 5

But that solution proved elusive. Pratt and Whitney, the engine manufacturers, blamed the propeller fabricators, Hamilton Standard, for oil leaks and materiel failures. Hamilton Standard, in turn, blamed Pratt and Whitney as well as Northrop, claiming that both firms had been warned that problems would be almost unavoidable in the giant 8bladed props. ${ }^{6}$ Hamilton Standard and Pratt and Whitney were sister companies: since the mid-1930s, both had been subsidiaries of the United Aircraft Corporation. ${ }^{7}$ But their close relationship apparently did not make it any easier for them to solve the $\mathrm{xB}-35^{\prime} \mathrm{s}$ propulsion problems. Because of the unusual amount of stress involved, Air Materiel Command determined that the maximum life of the propellers was only eighty hours, so that--assuming an average operational flight of eight hours--all the propellers would have to be scrapped after every tenth flight. 8 This was obviously unacceptable, as were the continuing propeller failures: the ninth test flight of the 
XB-35 suffered another gearbox failure, and the tenth flight ended with the $\mathrm{xB}-35$ limping home on two engines, again due to prop failure. 9

\section{Search for Solutions}

It was becoming clear that the propeller fiasco was causing a critical bottleneck in the entire B-35 program. The second $\mathrm{XB}-35$ was nearly complete, and the remaining service test YB-35s were in work as well, but the propulsion problems threatened to keep the entire fleet grounded indefinitely. In February 1947, a meeting was held at Wright Field to try to solve the problem:

Due to engineering difficulties and materiel failures encountered in dual rotation gearbox and propeller installations in XB-35 airplanes, investigation has been conducted to determine the most feasible method of obtaining flyable B-35 airplanes at an early date. . . . It was determined that single rotation gearbox . . would enable the first XB-35 to fly [again] at the earliest possible date. . . Hamilton Standard personnel were yery pessimistic about the dual rotation program.

Following this meeting, some of the dual rotation bugs were ironed out, and both $\mathrm{xB}-35 \mathrm{~s}--$ for a time--kept their counter-rotating props. But further purchases of all such equipment were cancelled, and the remaining service-test YB-35s were scheduled to be fitted with single rotation propeller systems. 11 By early 1948, even the two XB-35s had been retrofitted to the single-rotation configuration. 12

But the simpler single-rotation propellers also proved unsatisfactory. Maximum speed--one of the Flying Wing's 
unique strengths--was reduced, ${ }^{13}$ dealing yet another blow to the B-35 program. Northrop pilot Max Stanley expected the simple props to be ineffective, and was proven correct. As he recalled in 1980:

Finally, almost in desperation, the dual rotating propellers were removed and replaced with a single four-blade propeller. As expected, these propellers were incapable of absorbing and delivering the full power of the engines resulting in an unacceptable degradation in performance.

Air Force test pilots agreed. In March, 1948, when John Northrop suggested that a publicity program be set up to break current world records with his Flying wing bombers, the Air Force declined. The then-current record holders-primarily the P-80 fighter (for speed) and B-29 bomber (for distance)--had been well-tested before their record-breaking attempts, the Air Force reasoned. But pilot reports on the $\mathrm{XB}-35--e v e n$ with the new propeller arrangement--had been extremely negative, pointing out that the new configuration had resulted in lower performance and higher levels of vibration, both on the ground and in flight. As a result, Air Materiel Command recommended that both the XB-35 and its jet-powered successor, the YB-49, be subjected to further testing before any record-breaking attempts were made. ${ }^{15}$ The endless B-35 problems were fast causing Air Force interest to wane. At a conference on August 16, 1948, Materiel Command and Northrop representatives met to discuss what to do with the eleven YB-35s, none of which had yet flown. The group came up with four alternatives, two involving storing the $\mathrm{B}-35 \mathrm{~s}$ until better engines came along 
(at a minimum additional cost of 2.5 million dollars); the other two choices called for immediate conversion of $\mathrm{YB}-35 \mathrm{~s}$ to jet-powered B-49s (at an additional cost of 2.923 million dollars). 16

But just three days later, an Air staff letter to Air Materiel Command killed all four of the above options. Northrop was to be notified that no more money would be allocated to produce B-35s; Northrop was to take the available funds and use them to deliver a maximum number of YB-35s to the Air Force's Strategic Air Command for operational testing. 17 But a week later, on August 27, 1948, Air Materiel Command replied that there were not enough funds to turn over even a single YB-35 to SAC, because of unsatisfactory propulsion and exhaust systems. There were enough funds for preliminary flight tests of one YB-35, but the others would need to be either scrapped or stored. 18 The demise of the XB/YB-35 program meant that Northrop's hopes for a successful Flying wing bomber would have to rest on a variant of the B-35, the jet-powered YB-49s. Those aircraft, only two of which would ever be built, would now represent the future of the Flying wing bomber. 


\section{Chapter III Footnotes}

${ }^{1}$ Stanley, "The Flying Wings," p. 251.

2 Air Materiel Command memo, Subject: "Estimated cost of Number One XB-35 Up to Flight Test"; February 25, 1947. The unsigned memo estimates the cost of the first XB-35 at $\$ 14,300,000$, compared to Northrop's contract estimated cost of $\$ 2,910,000$.

${ }^{3}$ Stanley, "The Flying wings," p. 251.

${ }^{4}$ Ibid.

${ }^{5}$ Bill Gunston, "The All-Wing Northrops," Aeroplane Monthly, February 1974, p. 486.

${ }^{6}$ W.G. Knieriem to John K. Northrop; memo; October 18 , 1946. Knieriem's exact position at the time is unclear; subsequently he was a Northrop project engineer, but this memo was contained in the Air Materiel Command files. The author's frustration about the inability to get Pratt and Whitney and Hamilton-Standard to agree on a solution is clear: his memo ends with the comment: "Conclusinn--Feople are no damned good."

7 John B. Rae, Climb to Greatness: The American Aircraft Industry, $1 \overline{920-1960}$ (Cambridge, Massachussetts: The MIT Press, 1968), p. 54 .

${ }^{8}$ Status Report of Contract W535-ac-33920, December 1 , 1946. Unsigned report to the Chief, Bombardment Branch, Air Materiel Command Engineering Division.

${ }^{9}$ Northrop Aircraft to Army Air Forces officer-inCharge, Northrop Field; letter; May 8, 1947.

${ }^{10}$ Air Materiel Command Routing and Record Sheet, Subject: "Installation of Single Rotation Gear Box and Modified Propeller in YB-35 Airplanes"; February 17, 1947.

${ }^{11}$ Air Materiel Command Propeller Conference; minutes; April 15, 1947.

12 Air Materiel Command Routing and Record Sheet, Subject: "Progress Report on XB-35"; February 6, 1948.

${ }^{13}$ Gunston, "The All-Wing Northrops," p. 486.

${ }^{14}$ Stanley, "The Flying Wings," p. 251.

15 Air Materiel Command report to Major General F.o. Carroll, Director, Research and Development; March 23, 1948. 
16 Air Materiel Command Routing and Record sheet, from XB-35 and YB-49 Project Office to Colonel Gerrity, Chief, Bombardment Branch; August 16, 1948.

17 Lieutenant General H.A. Craig, Deputy Chief of Staff/Materiel, to Commanding General, Air Materiel Command; letter; August 19, 1948.

${ }^{18}$ Director of Procurement and Industrial Planning to Deputy Chief of Staff/Materiel, Air Staff; memo; August 27, 1948. 


\section{CHAPTER IV}

\section{THE YB-49: THE FLYING WING BOMBER}

IN THE JET AGE

Toward the end of World War II, the aviation world began to experiment with jet propulsion. The Germans introduced the twin-jet ME-262 fighter to the skies of Europe with considerable effectiveness, ${ }^{1}$ while American efforts focused on the less successful P-59 jet fighter. ${ }^{2}$ By 1945 it appeared that the future of jet propulsion was assured.

Against this backdrop, the Army Air Force and Northrop agreed in June 1945 to experiment with a jet-powered Flying Wing bomber. To minimize the development time required, it was determined that two of the original thirteen YB-35 service airplanes already on contract would be modified to jet propulsion. The new airplanes would be called YB-49s. ${ }^{3}$

The YB-49s were almost identical to the YB-35s in all but the propulsion system. The four $\mathrm{R}-4360$ engines with propellers that had caused so many problems for the $\mathrm{XB}-35$ were to be replaced by eight TG-180 jet engines, each with just 3750 pounds of thrust. ${ }^{4}$ substantial vertical fins were added for stability, replacing the engine housings and propeller shafts, and two of the eight bomb bays were converted to fuel tanks to feed the thirsty jet engines. 5 
The YB-49 program acquired new significance when it became apparent that the B-35 propeller problems might never be fully solved. In May of 1946, Air Materiel Command saw the YB-49 as a potential savior for the entire Flying wing program:

In view of the high propeller blade stresses and the elastic gearbox mounting difficulties presently being encountered on the $\mathrm{XB}-35$ airplane, it appears that the YB-49 might offer a desirable alternate power plant installation in the event a satisfactory solution to the above problem cannot be reached.

The AMC memo went on to describe the other principal benefit of the YB-49: speed. Its projected top speed was to be 465 miles per hour, versus 391 miles per hour for the $\mathrm{XB}-35$. The differential in cruising speed would be even greater: 400 miles per hour for the YB-49, against only 240 miles per hour for the $\mathrm{xB}-35$. But all this performance was not without its price: range with a 20,000 bomb load was expected to drop from 4175 miles to about 3500 . $^{7}$

Despite the generally encouraging figures, all realized that the YB-49 was not an optimal design. By the time the YB-49 was completed in october 1947, the authoritative magazine Aviation Week noted the fact that while its fuel consumption was four times that of the $\mathrm{xB}-35$, the extra bomb bay fuel tanks meant that range had been cut "only a little more than half." 8 While the short range was of concern, it was attributed to the fact that the YB-49 was a jet-age modification of a propeller-era airframe. A Northrop engineer wrote: 
The YB-49 airplane was originally conceived as a purely experimental jet-powered version of the $\mathrm{XB}-35$. The existing $\mathrm{xB}-35$ structure was to be revised. . only as necessary to allow the installation of the TG-180 engines and required extra fuel capacity.

And the Air Materiel Command agreed:

Although the YB-49 has obvious limitations, primarily due to the fact that it is a modification, it is considered that the airplape will be extremely valuable as a research project.

\section{Shortcomings as a Bomber}

Its characteristics may have made it a satisfactory research project, but it appeared that the YB-49 would be totally inadequate as a bomber. It had only six bomb bays: bays \#1 and \#8 on the XB-35 were converted to fuel tanks on the YB-49. Like the XB-35, the largest bomb which could be carried was 4000 pounds; larger standard Air Force bombs of 12,000 and 22,000 pounds could not fit at all. ${ }^{11}$ Incredibly, the YB-49, like the XB-35, could not even carry the atomic bomb. ${ }^{12}$ These shortcomings were well-recognized as early as 1946, and elements in the Air Staff were skeptical even then that the YB-49 would ever develop into an adequate bomber:

If procurement were initiated for the $B-49$, it would not reach tactical units before other bombers of the same class having equal performance and with provisions for carrying the $A$-bomb. Therefore it is felt that unless the B-49 can be modified to carry 13 the atom bomb, further procurement is unwarranted.

\section{Flight Tests}

Despite these reservations, work continued on the two YB-49s, and the first was successfully flown from 
Hawthorne to Muroc on October $21,1947 .{ }^{14}$ The first flight was uneventful, according to the test pilot Max Stanley, who stated in 1980 that the YB-49 program was far less troublefilled than that of the $\mathrm{XB}-35$ :

The YB-49 flight test program was as trouble-free as the $\mathrm{XB}-35$ was troublesome. All test objectives were met on or ahead of schedule. The airplane proved to be simple to fly with no special pilot skills required.

But other records paint a much different picture. The first flight did go according to plan. ${ }^{16}$ But on the YB-49's second flight, the nose gear door blew off, and the nose landing gear would not lower. Through a hastilyconvened radio conference, Northrop engineers were able to work with the pilot to get the landing gear down. ${ }^{17}$

Other problems existed as well: for example, constant-speeddrive generators, designed to provide electrical power for the YB-49, were deleted by government order, and replaced by auxiliary power units. These units, called APUs, failed frequently, first during tests and later in flight, and filled up three of the six bomb bays as well. 18

Despite these and other problems, the YB-49 test program did seem generally more successful than that of the $X B-35$. Northrop and the Air Force traded pats on the back, congratulating each other for having had the wisdom and fortitude to see the Flying Wing bomber program through the difficult XB-35 days. On December 19, 1947, Northrop wrote to Gen. Carl A. Spaatz, Air Force Chief of Staff:

You are well acquainted with the continuing problems concerning reduction gear and propeller operation 
that have kept the B-35s virtually grounded for eighteen months since the first one was flown to Muroc. Fortunately we have had better luck with the first jet-powered YB-49, and have been able to get almost as much time in two months with jets as was secured in eighteen months on the two XB-35s. As chief of the USAF, I am sure you will be happy to know that our best expectations concerning performance are being fulfilled. . . In other words, the project has already been proven highly successful. . . You can definitely uncross your fingers foncerning the value and success of the
project.

General Spaatz' comments on January 8, 1948, were less enthusiastic and more reserved than Mr. Northrop's. General Spaatz closed by saying:

All of us have been keenly disappointed over the failure to obtain adequate flight data from the $\mathrm{XB}-35 \mathrm{~s}$. We realize that your company is not at fault in this failure. The conclusive data which can be obtained by continued, intensive flight tests with the YB-49 is [sic] anxiously awaited.

\section{Materiel Command Reservations}

If General Spaatz appeared to be hedging a bit on the Flying wing bomber concept, he had very good reason. An internal Air Materiel Command memo, dated the day before General Spaatz' response, reflected the serious concern AMC had regarding the in-flight stability of the YB-49:

This section does not believe that adequate information or analysis has been made to thoroughly evaluate the probability of success of the Flying Wing . . the two unknowns which must be thoroughly evaluated before undertaking another wing airplane are as follows:

a. Inherent stability or artificially induced automatic pilot stability at cruising speeds (affecting the stable bombing platform).

b. High speed stability. . . This second problem cannot be minimized because an all-wing airplane. . will have all the problems 
associated with swept wings without the benefit of long tail lengths to 2 assist in the solution of those problems.

Even Max Stanley agreed that stability was indeed a problem:

A more serious shortcoming was revealed by flight tests which indicated that the YB-49 had very low yaw damping with oscillations extending over a period of as long as 10-12 seconds. This was a serious deficiency in the stability of the airplane and cast a dark shadow on the 2 suitability of the aircraft as a bombing platform.

So at this point the Air Force had a bomber with inadequate range, and which was incapable of carrying the atomic bomb--or even large conventional bombs, for that matter. In addition, the airplane tended to be unstable in flight, and yawed so much from side to side that accurate bombing results were thought to be unlikely. Still, despite all the Air Force's qualms, Northrop continued to lead the cheers for the Flying wing bombers:

Flight tests compiled to date on $\mathrm{XB}-35$ and $\mathrm{YB}-49$ airplanes have fully confirmed expected high performance of those airplanes, as well as the fact that they have features of stability and controlability rendering ${ }_{3}$ them entirely satisfactory for bombing missions.

\section{Tests of Range}

For a time in the early part of 1948 , the YB-49's future began to brighten. The second $Y B-49$ made its maiden flight on January 13, and soon joined its partner in flight tests at Muroc. 24 Distance tests in April led to a record-setting flight, in which a YB-49 stayed aloft for more than nine hours, covering more than three thousand miles enroute from Muroc to San Francisco to Phoenix and back to 
Muroc. While this was a record endurance for jet aircraft, and while it was accomplished with one engine shut down for part of the flight, it was only about one-third of the original ten thousand mile specification laid out for the Flying Wing bomber in 1942. ${ }^{25}$ Still, the results were encouraging enough that the new Air Force Chief of Staff, Gen. Hoyt S. Vandenberg, wrote to Mr. Northrop on May 12, congratulating him on the successful test flights. ${ }^{26}$

\section{Disaster}

On June 5, 1948, Maj. Daniel Forbes and Capt. Glen Edwards, along with three other crewmembers, were scheduled to take up the second YB-49 for what should have been a routine test flight. In the nearly five months since its maiden flight, the second YB-49 had flown twenty-seven times, for a total of about sixty-six hours in the air. The first twenty-four flights had been under the control of Northrop, but on June 4 , the YB-49 was transferred to the Air Force. Three flights on the day of transfer totalled nearly eleven hours, and the fourth Air Force flight was scheduled for the next day, June 5 th. 27

The YB-49 took off from Muroc at 5:44 A.M., and reported twenty-six minutes later, over Bakersfield, California. At 6:33 A.M., the crew, by then over the north end of the Antelope Valley, reported decending through fifteen thousand feet. That was last ever heard from the YB-49 crew. At approximately 7:03 A.M., the bomber was seen to fall, tumbling from the sky north of Muroc. ${ }^{28}$ 
Only a few people witnessed the crash, and by the time they saw the aircraft, it was already tumbling out of control. One eyewitness was Maj. Russ Schleeh, an Air Force fighter test pilot whose career would later become closely entwined with the remaining YB-49:

I was en route to the North Base from the Muroc Main Base by auto when something attracted my attention on the west side of the road on which I was traveling. At first it appeared to be falling pieces of metal. Probably it was the outer wing panels or control surfaces that caught my eye. I then glanced north and noticed the main section of the airplane tumbling and later contacting the ground just north of the Mojave-Victorville highway. I rushed to the scene after scanning the sky for parachutes and rummaged around the wreckage but could not identify anything of consequence due to the impact damage and resultigg fire and total destruction of the aircraft.

There were no parachutes: all five men aboard the YB-49 were killed. Muroc was later renamed Edwards Air Force Base in honor of the copilot Edwards. But like many events surrounding the Flying wing program, exactly what happened on that June morning is a matter of dispute. Max Stanley, in his 1980 speech, did not even mention the crash; he alluded only briefly to the YB-49's "reputation as an airplane with unacceptable stall characteristics," a reputation he claimed was not deserved. 30 The official Northrop history implies that the crew simply exceeded the design limits of the airplane, perhaps descending at too high a speed. 31 Ed Maloney, in his not-always-unbiased book, Northrop Flying Wings, makes a similar suggestion: "It is assumed that. . the 'not to exceed' limits of the aircraft were exceeded while descending from 40,000 feet." 
Maloney admits, though, that this is speculation, and that "what exactly happened is not known." 32

But Air Force records, while they do not point conclusively to the cause, indicate that the problem wasn't a result of the highly experienced crew simply going too fast. Rather, the records point, albeit inconclusively, toward an accident which resulted from a stall, the same maneuver Max Stanley said was so safe, but a maneuver which records show Air Force pilots were apparently reluctant to even attempt.

Two days after the crash, Northrop Engineering Test Pilot F.C. Bretcher dispatched a memo to Northrop headquarters in Hawthorne. Bretcher wrote that, although his information was not to be considered final, he had learned the agenda for the fatal test flight. Takeoff was to be followed by a climb to forty thousand feet, when "speedpower runs," i.e., how much power was required to reach a given airspeed, were to be conducted. The crew was to gather data on exhaust temperatures, and then shut down and restart two engines. The final event was to involve one stall, probably at ten thousand-fifteen thousand feet. 33

since the last radio call from the crew was at fifteen thousand feet and descending, and since the crew reported no problems at that time, it seems reasonable to conclude that the disastrous loss of control probably happened during the stall tests. But that last radio call was at $6: 33$ A.M., and the crash did not occur until 7:03, a half-hour later. One stall shouldn't take thirty minutes; if the Bretcher memo 
was correct, what else was the crew doing in addition to that single stall?

A later Air Force document suggests the answer. Lt. Col. Frank J. Collins, in an official statement in the records of the crash probe, confirmed most of the Bretcher memo. However, there was not just one stall on the schedule, as Bretcher had thought. Rather, a whole series was to be accomplished, at progressively higher power settings: "If the airplane proved to handle cleanly during these stalls, stalls with higher power settings were to be obtained." This clearly implies that there was a lot yet to learn about the stall characteristics of the YB-49. What did Forbes and Edwards, experienced Air Force test pilots, think of the stall tests in the YB-49? The Collins memo continues: "It is known that the pilot was reluctant to attempt the higher power stalls." 34

So, the June 5 crash probably occurred while the crew was attempting a series of stalls, each one at higher power settings than the last. Further, the stalls were thought to be dangerous enough that an experienced Air Force test pilot, a man not unaccustomed to risk, was reluctant to perform them. The comments of Northrop pilot Stanley--that the stall characteristics of the YB-49 were acceptable--seem to be contradicted by these documents, and by the tumbling airplane that fell out of the sky on a sunny June morning in 1948 . 


\section{Aftermath}

Surprisingly, the crash did not kill the YB-49 program. The surviving YB-49 was grounded for inspection and some modification, but was later reentered into the flight test program. In the meantime, Convair's giant B-36 bomber had run into problems, and the Air Force had decided to stop production at the ninety-fifth aircraft. But the B-36 plant at Fort Worth was twice the size of the Northrop plant and it was government-owned. The Commanding General of the Air Materiel Command decided that it was necessary to keep the Fort Worth plant operating, and if the B-36 could not be continued, another bomber would have to be substituted. AMC decided to try to convince the Air staff to build the B-49 in quantity. On June $17,1948--j u s t$ twelve days after the fatal crash--Gen. Joseph T. McNarney wrote to the Air Force Chief of Staff recommending purchase of fifteen B-49s per month, most of which would be built at Fort Worth, by Convair through a subcontract arrangement with Northrop.

This was a most extraordinary letter. No mention was made of the crash, nor was there any indication that the Strategic Air Command, the ultimate user of the bomber, supported the request. General McNarney based his recommendation solely on the need to keep the Fort Worth plant open, and suggested that the money for the B-49s come from cancellation of thirty North American B-45 bombers per month. 35 
The Air Staff was not convinced. While they agreed that cancellation of North American's B-45 was a good idea, they strongly disagreed with the notion of building more B-49s, at Fort Worth or anywhere else. In addition to the fact that the recent crash indicated that the YB-49 obviously required more testing, the Air Staff pointed out that its short range classed the YB-49 as a medium bomber, and the Air Force already had enough medium bombers. General McNarney's recommendation was turned down. ${ }^{36}$

\section{More Flight Test Problems}

The Air Staff decision was later validated by further tests. In addition to all the previous shortcomings of the YB-49 as a bomber, tests in November 1948 showed that the YB-49 was incapable of even performing a satisfactory bomb run. The test pilot, then-Major Robert Cardenas, was quoted as stating the plane was "extremely unstable and very difficult to fly on a bombing mission. . . continual yawing - . made it impossible to hold a steady course or a constant airspeed and altitude." Bomb runs took four times as long as similar runs with a B-29, and accuracy was only half as good. Air Materiel Command recommended that the YB-49 stay at Muroc until aerodynamic problems were fixed, and that until that time, the YB-49 was believed to be unsuitable for either bomber or reconnaissance work. ${ }^{37}$

November 16, 1948, marked the effective end of the YB-49 program. On that date, Brig. Gen. K.P. McNaughton, Acting Director of Training and Requirements, wrote to 
Gen. Muir S. Fairchild, Air Force Vice Chief of Staff. In the memo General McNaughton stated that there was no longer any requirement for the B-49 bomber. It was already inferior to Boeing's new B-47, which had topped six hundred miles per hour in testing, and would soon be competing against the B-52, expected to be even better than the B-47. General MCNaughton recommended that the B-49 be dropped. 38

By February 1949, the decision had been made. The surviving YB-49 would continue flight testing. Another YB-35 would be modified to a reconnaissance version, and three more YB-35s would be turned into flying test beds for various purposes. All other Wings would be scrapped, saving the Air Force approximately $\$ 7,500,000$, when compared to the cost of completing production on all the aircraft in progress. 39 On October 28, 1949, the Air Force finally cancelled most of the remaining program: only the YB-49, permitted to continue flight test, and the YRB-49, the reconnaissance conversion, that had not yet flown, survived. 40

\section{Epilog}

The second YB-49 continued in the flight test program. In April, 1949, a new chief Air Force test pilot was brought in. The man chosen had previously served as Chief of Fighter Flight Test at Wright Field: Maj. Russ Schleeh, the same Russ Schleeh who had been an eyewitness to the Forbes/ Edwards crash nine months before. ${ }^{41}$

On March 15, 1950, the remaining YB-49 was destroyed 
in a taxi accident. Once again, the cause of the crash was a matter of disagreement. The Northrop history blamed the Air Force pilot, claiming that Major Schleeh had tried to turn the nose wheel at too high a speed:

- this same airplane was destroyed one year later (March 15, 1950) during an excessively highspeed turn while taxiing on the runway at Edwards Air Force Base. The nose gear collapsed, flipping the airplane completely over. All of the crew escaped unharmed.

But once again, the Air Force perspective was different. According to the military records, the real cause was a failed or unserviced "shimmy damper," a device which controls the tendency of a nose gear to wobble. This interpretation is backed up by crash photos, which show a long sinuous streak of rubber, with the oscillations becoming worse just before the gear finally collapsed. From the Edwards Air Force Base history:

A stability test to determine the nose gear liftoff speed at forward cg [center of gravity] was being conducted on the dry lake bed when a violent nose gear shimmy was encountered near lift-off speed. The vibration became so severe as to cause failure of the nose gear strut. The fuel leaks and subsequent fire. . . resulted in destruction of the aircraft. All personnel were able to leave the airplane, although the pilot, Major R.E. Schleeh, and engineer, Captain M. French, 4 both of the AMC Flight Test Division were injured.

Thus the destruction of the sole surviving YB-49 ended the story of the flying wing bombers. Only one aircraft remained--a reconnaissance model called the YRB-49--and it had not yet flown when the second YB-49 crashed at Edwards. But it would fly two months later, and it would come to represent still another strange aspect of the Flying Wing story. 


\section{Chapter IV Footnotes}

${ }^{1}$ Walter J. Boyne, Messerschmitt Me-262: Arrow to the Future (Washington: Smithsonian Institution Press, 1980), pp. $41-57$.

${ }^{2}$ United States Air Force Museum (Wright-Patterson AFB, Ohio: Air Force Museum Foundation, Inc., [1979]), p. 56. 3 1945. The change covered conversion of two YB-35s to YB-49s, for a total increase in estimated cost of $\$ 1,644,603$.

${ }^{4}$ Gunston, "The All-Wing Northrops," p. 487.

${ }^{5}$ Captain Farry to Brig. Gen. A.R. Crawford, DCS/ Materiel; Confidential memo; october 7, 1946.

${ }^{6}$ Lts. R.D. Hodge and E.R. Feicht to Lt. Col. H.E. Warden; office memo, Subject: "Justification of the YB-49"; May $10,1946$.

7 Ibid.

8 "Flying Wing Jet Bomber Completed," Aviation Week, October 17,1947 , p. 14.

${ }^{9}$ W.G. Knieriem, Northrop Project Engineer, to Commanding General, Air Materiel Command; letter; August 5, 1947.

10 Hodge/Feicht memo.

${ }^{11}$ Farry memo. Recognizing that the inability to carry large bombs would seriously hamper the Flying wing bombers' usefulness, Northrop proposed a semi-external carriage system. Air Materiel Command quickly turned down the proposal, noting the the big bombs would need to hang within twelve inches of the $\mathrm{XB}-35^{\prime} \mathrm{s}$ propellers.

\section{Air Materiel Command Routing and Record sheet,} Subject: "Summary of B-35 Program"; April 7, 1947. The memo noted that many of the same problems plaguing the $B-35$ would also affect the YB-49. In addition to the inability to carry the atomic bomb, the problems noted included poor defensive armament, poor crew accommodations, "terrific" maintenance problems and the requirement that, in order to get the maximum bomb load aboard, the largest bomb possible was the relatively small 1600-pounder. The memo concluded by saying that the YB-49 "tactically does not appear much better than the proposed B-50 condition two," a development of Boeing's B-29 bomber. 
${ }^{13}$ Major General E.M. Powers, Assistant Chief of the Air Staff, to Commanding General, Air Materiel Command; Confidential letter; November 5, 1946.

14 "World's Most Powerful Plane Takes to Air for First Time," Los Angeles Times, October 22, 1947, p.3. This date is confirmed by other sources including Northrop test pilot Max Stanley, but is at variance with Northrop Flying wings, by Edward T. Maloney, which places the first flight on October 1, 1947. See also "Jet Wing Flies," Aviation Week, October 27, 1947, p. 14, and "YB-49 Heads for Muroc and Army Flight Tests," Aviation Week, November 3, 1947, p. 13.

${ }^{15}$ stanley, "The Flying Wings," p. 252.

16"World's Most Powerful Plane Takes to Air for First Time," p. 3 .

${ }^{17}$ Lt. Col. Sydney T. Smith to Colonel G.F. Smith, Air Materiel Command; letter, Subject: "Second Flight of the YB-49"; October 24, 1947.

${ }^{18}$ John K. Northrop to Commanding General, Air Materiel Command; letter; October 17, 1947.

19 John K. Northrop to Gen. Carl A. Spaatz, Air Force Chief of Staff; letter; December 19, 1947.

${ }^{20}$ Gen. Carl A. Spaatz, Air Force Chief of Staff, to John K. Northrop; letter; January 8, 1948.

21 Air Materiel Command Internal Memo from Colonel G.F. Smith, Chief, Aircraft Projects Section; January 7, 1948 .

${ }^{22}$ stanley, "The Flying Wings," p. 253.

23 John K. Northrop; Confidential memo; January 24, 1948. Exactly to whom the memo was addressed is not clear, but the fact that it rests now in the old Air Materiel Command files seems to indicate an Air Force audience.

${ }^{24}$ Commander, Air Force Flight Test Center, to Commander, Air Materiel Command; message number $252330 \mathrm{z}$ Mar 50; March 25, 1950.

${ }^{25}$ Lt. Gen. H.A. Craig, DCs/Materiel, to Air Force Chief of Staff; Confidential memo; April 27, 1948. See also followup memo from General Craig to Chief of Staff, April 29,1948 .

${ }^{26}$ Gen. Hoyt S. Vandenberg, Air Force Chief of Staff, to John K. Northrop; letter; May 12, 1948. 
27 Message number $252330 z$ Mar 50 .

${ }^{28}$ F.C. Bretcher, Northrop Engineering Test Pilot, to J.W. Myers; memo; June 7, 1948 .

${ }^{29}$ R.E. Schleeh to E.T. Wooldridge, National Air and Space Museum; letter; November 24, 1982; p. 2. Copy to the author, January 19, 1983.

${ }^{30}$ Stanley, "The Flying Wings," p. 253.

${ }^{31}$ Anderson, Northrop: An Aeronautical History, p. 104.

${ }^{32}$ Edward T. Maloney, Northrop Flying Wings (Corona

del Mar, California: World War II Publications, 1980), p. 27.

${ }^{33}$ Bretcher memo.

${ }^{34}$ statement by Lt. Col. Frank J. Collins, undated, contained in records of YB-49 crash investigation. Lt. Col. Collins' position at the time is not clear, nor is it clear exactly which pilot--Forbes or Edwards--was reluctant to do the high power stalls. For more on stalls, see chapter VIII.

${ }^{35}$ Gen. Joseph T. McNarney, Commanding General, Air Materiel Command, to Chief of Staff, USAF; letter; June 17, 1948. General McNarney later became President of Convair, and some have since implied that his interest in keeping the Fort Worth plant open was not entirely related to the enhancement of national defense. This issue will be addressed in more detail in a subsequent chapter.

${ }^{36}$ Colonel J.T. Perkins, Acting Deputy, Requirements Division, to General Partridge, DCS/Operations; memo; June 25, 1948. See also Air Staff Summary Sheet, undated, Subject: "Procurement of B-49 Airplanes."

37 Aircraft Branch, DCS/Materiel, to Brigadier General Putt, Director of Research and Development; unsigned memo; November 8, 1948. See also Armament Laboratory Memo MCREXG-552-581, November 16, 1948, and Flight Test Division Memo MCRFT-2182, December 3, 1948.

${ }^{38}$ Brigadier General K.P. McNaughton, Acting Director, Training and Requirements, to Gen. Muir S. Fairchild, Air Force Vice Chief of Staff; Confidential memo; November 16 , 1948 .

${ }^{39}$ Director of Research and Development to Major General E.M. Powers, Assistant DCS/Materiel; Confidential memo; February 25, 1949.

40 Anderson, Northrop: An Aeronautical History, p. 108. 
${ }^{41}$ Schleeh letter, p. 1.

42 Anderson, Northrop: An Aeronautical History, p. 106.

${ }^{43}$ History of Edwards Air Force Base, January-June 1950, p. 103 . 
CHAPTER V

THE RECONNAISSANCE VERSION OF THE FLYING WING:

THE YRB-49

So far, our review of the Flying wing bombers has shown that only fifteen airframes were ever ordered from Northrop, and that the orders for those fifteen were all placed by 1942. We have seen that for a number of reasons, including range, stability, and bomb carrying capacity, serious doubts existed within the Air Force as to the suitability of the $\mathrm{XB}-35$ and $\mathrm{YB}-49$ Flying Wing bombers.

But we have also seen Mr. Northrop's claim that the Air Force placed another order for thirty-five aircraft in 1948. This order, if it existed as Mr. Northrop claimed, would be significant, since it would suggest that the Air Force's reservations about the Flying wing bombers had at last been overcome. Mr. Northrop described the order clearly in his 1979 interview:

Generaf McNarney, who was the chief of the Air Force, 1 walked into my office one morning in late June of 1948 and said, "You have won the competition. Here is an order for thirty-five additional aircraft" and I took a deep breath and said, "Oh, that's wonderful" and he said, "That's only a drop in the bucket. We probably will need between twg hundred and three hundred of these airplanes."

Northrop test pilot Max Stanley confirmed that a 1948 production contract for Flying wing bombers was given to 


\section{Northrop:}

The Air Force furnished a bombardier who arrived at Muroc with the then highly secret Norden bomb sight. After evaluating the results of a lengthy series of bomb drops under varying conditions, the aircraft was accepted by the Air Force as a satisfactory bombing platform, and a production contract was awarded Northrop by the Airr Force. It was, however, a controversial decision.

Despite the fact that both $\mathrm{Mr}$. Northrop and his chief test pilot agreed that a production contract for Flying wing bombers was awarded in 1948, Air Force records show no such order. In fact, Air Force documents show clearly that no Flying Wing bombers were ordered from Northrop after the fifteen experimental and service test airplanes were ordered in 1941 and 1942. What, then, is responsible for this discrepancy? Were the memories of Mr. Northrop and Max Stanley faulty? Or are the surviving Air Force records inaccurate or incomplete?

The answer is really neither. There was an order placed in 1948. The number of aircraft ordered was not thirty-five, as Mr. Northrop recalled, but thirty, and the planes were not to be bombers: the Air Force was at that time apparently still convinced that the Flying Wings were not going to prove satisfactory as bombers. Instead, the Air Force reasoned that if the YB-49 was too unstable and unusable as a bomber, perhaps it could be adapted to another role. This line of reasoning dovetailed well with the Air Force's search for a long-range reconnaissance aircraft, and it was those, not bombers, that the Air Force finally ordered in 1948. The airplane came to be called the 
YRB-49 ("YRB" indicating that it was to be a test version of a reconnaissance modification of a bomber design) and it developed into another unusual chapter in the story of the Flying Wing's development.

\section{The Need for a New Reconnaissance Aircraft}

In a letter dated March 12, 1946, Gen. Carl A. Spaatz, Commanding General of the Army Air Forces, outlined the mission of a newly established combat force:

The Strategic Air Command will be prepared to conduct long range offensive operations in any part of the world, either independently or in cooperation with land and naval forces; to conduct max-4 imum range reconnaissance over land or sea. . .

But SAC's ability to carry out "maximum range reconnaissance over land or sea" was pretty doubtful in the late 1940s. By 1948, SAC's entire reconnaissance force consisted of just fifty-eight aircraft, nearly all of which were relatively short-range RB-17s or somewhat more capable RB-29s. Both of these aircraft were designed prior to World War II; neither possessed the capabilities that SAC needed. ${ }^{5}$

On April 12, 1948, a meeting was convened at Wright Field, the purpose of which was to determine which of three aircraft was best capable of meeting the reconnaissance requirements of the Strategic Air Command. At that meeting,

Considerable discussion followed as to which aircraft, the F-12, FDC-6, or FB [later RB] -49 could best meet the overall technical requirements. In addition, consideration was given to the respective manufacturer's capability and contemplated workload.. . It was agreed that the FB [RB]-49 showed the greatest possibilities for development and in its interim stages could most realistically 
accomplish a portion of the overall strategic re-
connaissance mission.

The conferees went on to recommend that the FB/RB-49 be procured in three stages, based on Northrop's projected improvements. The first group of aircraft would be powered by eight relatively primitive jet engines; while it could be available by January of 1950, it would have only about half of the desired ten-thousand-mile range. The second batch of airplanes would have only six jet engines, but they would be more powerful than those in the previous model. Range would improve to 5,640 miles, but the delivery would have to wait until December of 1950. Waiting still one more year, until late 1951, would allow the development of the third and ultimate version of the RB-49. This would use two jets and two gas turbine power plants, which would theoretically combine to achieve a range of 9,320 miles.

This proposed three-stage purchase of the RB-49 was not an optimal solution. The Air Force felt that the range of the first version was insufficient, but apparently believed that the improvements projected for versions two and three would raise performance up to acceptable levels:

Although the range of the first version of the [R]B-49 was realized to be inadequate, subsequent versions of the aircraft, equipped with different engines, were expected to show considerable improvement. All in all, the $[R] B-49$ appeared at the time to be the most promising of the different airplanes ${ }_{8}$ available for strategic reconnaissance purposes.

On May 3, 1948, the Air Force notified Northrop of the decision to buy thirty of the RB-49s, version one: ${ }^{9}$ 
Contractor is advised that the AMC [Air Materie] Command] anticipates procuring thirty $\mathrm{FB}[\mathrm{RB}]-49$ airplanes incorporating eight J-47A engines... Minimum delivery schedule as follows:

$\begin{array}{clc}1949 & \text { December } & 1 \\ 1950 & \text { January } & 1 \\ & \text { February } & 2 \\ \text { March } & 2 \\ \text { April } & 3 \\ \text { May } & 3 \\ \text { June } & 3 \\ \text { July } & 3 \\ \text { August } & 3 \\ \text { September } & 3 \\ \text { October } & 3 \\ \text { November } & 3\end{array}$

But the Air Force let Northrop know that a three aircraft/month schedule was not considered satisfactory:

Above schedule has been quoted as contractor's best schedule, however USAF considers earlier availability of FB[RB]-49A production airplanes mandatory. Therefore contractor is requested to determine how pych time could be gained by all-out overtime. . .

The Air Force, though, didn't have a clear picture of the problem. The slow delivery schedule was due less to the shortage of labor than to the same plant capacity problem that had plagued Northrop for the entire decade. By late 1948, Northrop still had only about 1.2 million square feet of plant space, only about 20 percent of Convair's 5.8 million square feet. ${ }^{11}$ Thus the three deliveries per month rate was about all that the Hawthorne plant could support.

\section{Impetus of Berlin}

In the spring of 1948, the Air Force apparently felt it could live with the three planes-a-month schedule. By the summer, though, things had changed. After months of 
increasing tension, the Soviets blockaded the city of Berlin on June 24. The questionable combat readiness of the Strategic Air Command received new attention as President Truman ordered deployment to Europe of ninety SAC bombers and additional reconnaissance aircraft. ${ }^{12}$

Renewed emphasis on SAC meant renewed emphasis on the reconnaissance procurement effort. Suddenly, more aircraft were thought to be needed, many more than Northrop could deliver. The industry magazine Aviation Week commented on the Air Force's increased needs, and on Northrop's inability to satisfy them:

Northrop's productive capacity of only three bombers per month at its Hawthorne, California facilities cannot meet the acceleration of the program desired by the Air Force.

A week before the mounting tensions in Germany culminated in the Berlin Blockade, General McNarney, Commander of Air Materiel Command, had recommended to the Air Staff an accelerated rate of fifteen RB-49 aircraft per month. Since Northrop could only produce 20 percent of those, General McNarney recommended that the remainder be built at the government-owned, Convair-operated plant at Fort Worth, which was then turning out the B-36 intercontinental bomber. This arrangement would provide a dual benefit: first, the increased production could be used by SAC to more quickly upgrade its strategic reconnaissance force. Second, the scheme would allow the Fort Worth plant to keep operating after the ninety-fifth (and expected to be last) B-36 was completed. 14 
The Air Staff, feeling that the Flying Wing was still unproven, disagreed with General McNarney's proposed boost in production, but did (with the apparent approval of secretary of the Air Force symington) authorize the transfer of RB-49 production to the soon-to-be-idle Fort Worth factory. In a letter to General McNarney, Gen. Hoyt S. Vandenberg, Air Force Chief of Staff, clearly indicated his concern about the continuation of Fort Worth production, and alluded to a possible increase in $\mathrm{RB}-49$ procurement:

- . you are authorized to arrange for the transfer of FB[RB]-49 production from the Northrop plant to the Fort Worth plant in order to continue production upon expiration of the B-36 contract and to provide for adequate production facilities for current and future production of the FB[RB]-49.

On June 30, 1948, General McNarney notified both

Convair and Northrop of the decision:

It is the desire of the Air Force to retain the production facilities at Fort worth which is now employed in the construction of B-36 airplanes. Since it is not intended to buy more than the ninety-five B-36 airplanes presently on contract, it is desired that the production of $\mathrm{RB}-49 \mathrm{~s}$ be moved to that facility at the earliest possible date. An absolute minimum number of RB-49s will be built at the present Northrop facility at Hawthorne . . . It is requested that representatives of Northrop Aircraft and Consolidated Vultee Aircraft arrange the necessary plans for carrying out this program with the least possible delay.

General McNarney's letter was perhaps a classic in bureaucratic miscommunication. In this single communique, he completely recast an $\$ 84,000,000$ contract, and told two competitors to simply work out the details between themselves. . quickly. But the "details" were staggering: did the General mean that Northrop should take over the Fort 
Worth plant? Or did he mean that Northrop should just turn over its designs, its tools, and its expected profits to Consolidated Vultee? Just who was to be in charge in the Fort Worth plant? Exactly how were the profits of the joint venture to be allocated?

The record shows that the McNarney letter was as ambiguous to Northrop and Convair as it appears in retrospect thirty-five years later. On July 9, 1948, John Northrop wrote back to General McNarney: Northrop management had met with Convair officials, he explained, but the meeting had not been productive. Northrop had understood General McNarney's letter to mean that Convair would simply vacate the Fort Worth plant, turning everything over to Northrop. Not surprisingly, Convair understood nothing of the kind: they construed the McNarney letter to mean that Northrop would merely subcontract RB-49 production to them, and that they would continue to operate the Fort Worth facility. Mr. Northrop asked General McNarney for help in ironing out the differences, but at the same time went to great length to deny any improper behavior by Convair:

Under the circumstances, nothing further can be accomplished by conversation between Northrop and Convair concerning the plans for Fort Worth production of the RB-49 airplanes until the desires or requirements of the Air Force are set forth more specifically . . . This is especially true because of the friendly relations existing between the companies and the necessity of maintaining such relationships in the event that Northrop is to operate in the Fort worth plant. . . It should be noted that Convair's attitude was not arbitrary or unreasonable. It was what might be expected of any business organization, based on the fimited information available to them at this time. 


\section{The Merger}

To iron out the problems generated by General McNarney's letter, a second meeting was held on July 16 , 1948. The meeting took place in Los Angeles, and was attended by officials of Northrop, Convair, and the Air Force. Secretary of the Air Force symington was in Los Angeles to fulfill a long-standing commitment to speak at the annual meeting of the Institute of Aeronautical Sciences. He and his host, Mr. John McCone of President Truman's Air Policy Commission, invited the Northrop-Convair-Air Force conferees to Mr. McCone's house for a discussion. ${ }^{18}$

The group addressed the problem of producing the RB-49 at Fort Worth. During this discussion, the possibility of a merger between Convair and Northrop was raised, not by the Air Force representatives, but by Floyd odlum, president of the Atlas Corporation, parent company of Convair.

In the course of the conversation, Mr. Odlum suggested a merger between the Northrop and Consolidated organizations as the best way of combining the Northrop engineering talent with Consolidated's production know-how. The suggestion seemed reasonable to the Air Force representatives since Northrop was not organized for a venture requiring as much capital as the quantity production of the [R] B-49.

Mr. Northrop was not in favor of a merger at that time and preferred an interim solution of the financing problem by subcontracting the production work to Consolidafed. This was the solution finally agreed upon.

Mr. Northrop's testimony at the 1949 House Armed Services Committee supports this account. After acknowledging that his firm lacked the capacity to handle the increased purchases then being contemplated, ${ }^{20} \mathrm{Mr}$. 
Northrop described the July 16 meeting:

MR. NORTHROP: The conclusion that was arrived at after very lengthy discussions was that the best solution to the problem consisted in [sic] Northrop subcontracting the actual construction of a major portion of this contract to Convair who would continue to operate the Fort Worth facility.

COMMITTEE COUNSEL: . . Did you believe that was the best solution?

MR. NORTHROP: Considering all factors, yes. Considering Northrop, no. But we felt it was the right thing to do in view of all the circumstances that were presented to us. . .

COUNSEL: Was there any evidence of any politics in that deal?

MR. NORTHROP: No, sir. . . It appeared to us to be a logical solution to a difficult problem. No contractor gladly gives up the manufacture of his own product. We would have much preferred to have found a solution that would have prevented that result. . .

COUNSEL: One of the prime reasons for taking that work away from you was to keep the Fort Worth factory busy.

MR. NORTHROP: That is correct.

COUNSEL: And another reason was to be sure you would get the accelerated output.

MR. NORTHROP: That is correct.

COUNSEL: But what proportion one did bear to the other in the solution you are unable to enlighten the committee.

MR. NORTHROP: That was the point I wanted to make. 21

\section{Air Force Questions}

While Mr. Northrop testified that he thought the arrangement was a "logical solution to a difficult problem," people in the Air Force had doubts. On August 16, 1948 , 
exactly a month after the Los Angeles meeting, the Procurement Committee of the Directorate of Procurement and Industrial Planning raised two questions concerning the production of RB-49 aircraft:

1. Why was it necessary to involve Convair at all? Why couldn't Northrop build the planes in the Fort worth plant since it was a government-owned facility?

2. If Convair was to be involved, why were they to receive only one-third of the profit, while Northrop, who would only produce one of the thirty planes, was scheduled to receive two-thirds of the profit? ${ }^{22}$

Two days later, Col. George Schaetzel, the Chief of the Aircraft and Missile Section, Procurement Division, answered both questions. As to why Convair had to be involved, his answer implied that the need to keep the Fort Worth plant open was the overriding consideration:

It has been determined by HQ USAF that there is a strategic requirement for building B-49 type airplanes in the Fort Worth facility. In addition, since it is contemplated that production of B-36s at this facility will be discontinued by November 1949 [still 16 months away] it is considered imperative that a large strategic airplane be built at that facility in order to make use of the plant and the production organization. . . . It would be very difficult to administrate [sic] this contract and the contract for the B-36 with both Consolidated Vultee Aircraft Corporation and Northrop Aircraft, Inc., in the Fort Worth facility as prime contractors. For these reasons, the secretary of the Air Force required Northrop Aircraft, Inc., to subcontract the major portion of the thirkty (30) RB-49A airplanes to Consolidated. . . .

Regarding the second question, suggesting that the profit distribution was too generous to Northrop, Colonel Schaetzel 
also disagreed:

Through the arrangement as directed by the Secretary of the Air Force, Consolidated has the opportunity to maintain their production organization intact and to use the Fort worth facility. The advantage to Consolidated through this arrangement is far in excess of any fee which might be paid.

\section{Summary}

So, as the summer of 1948 waned, the situation looked like this: thirty RB-49s were on order, with at least the possibility of a great many more to be ordered in the future. While it was true that all but one of the airplanes would be built by Convair at Fort worth, the arrangement seemed to have something for everyone. Northrop's airplane would finally be built, and they would receive twothirds of the profit. Convair would receive one-third of the profit, and would retain their production organization and the right to continue operating at Fort Worth. The Air Force would be able to get more airplanes faster, especially if the contemplated increase in orders took place, and the Air Force would maintain operation of a major aircraft plant. It seemed to be a solution that gave no one everything they wanted, but which reasonably addressed the conflicting needs of Northrop, Convair, and the Air Force. 


\section{Chapter V Footnotes}

${ }^{1}$ Actually, General McNarney was the Commander of Air Materiel Command. The Air Force Chief of Staff at the time was Gen. Hoyt S. Vandenberg.

2 "The Flying Wing--What Happened to It?"

${ }^{3}$ Stanley, "The Flying Wings," pp. 253-254.

${ }^{4}$ Harry R. Borowski, A Hollow Threat: Strategic Air Power and Containment before Korea (Westport, Connecticut: Greenwood Press, 1982), pp. 32-33.

${ }^{5}$ Development of the Strategic Air Command, 1946-1976, loffutt AFB, NE: Office of the Historian, Headquarters Strategic Air Command, [1976]), p. 11.

6 Unsigned confidential memo to Deputy Chief of Staff/Materiel, April 15, 1948. Subject: "Procurement of Strategic Reconnaissance Aircraft." The confusion involved in usage of "F" or "RB" designations was caused by a change in aircraft nomenclature in 1948. Up to that time, fighter aircraft were given "P" (for "pursuit") prefixes, e.g., $\mathrm{P}-38, \mathrm{P}-40, \mathrm{P}-51$. Reconnaissance craft were prefixed by "F" (for "foto," possibly), e.g., FB-49, FDC-6. In mid-1948, fighters became "F"-prefixed, e.g., F-86, F-89, and reconnaissance aircraft aircraft gained the "R" designation they still hold today, e.g., RB-49, RB-36, RF-4.

${ }^{7}$ Ibid., p. 3 .

${ }^{8}$ Maj. Gen. F.H. Smith, Jr.; testimony before House Armed Services Committee, Investigation of the B-36 Bomber Program, Hearings on H.R. 234, p. 68

${ }^{9}$ Headquarters Air Materiel Command to Northrop Aircraft Inc.; teletype; May 3, 1948.

10 Ibid.

11 "Industry Regains Health and Productivity," Aviation Week, February 28, 1949; p. 20.

12 A Hollow Threat, p. 125.

13 "Air Force to Boost B-49 Orders," Aviation Week, August 2, 1948; pp. 11-12. 
${ }^{14}$ Gen. Joseph T. McNarney, Commanding General, Air Materiel Command, to Chief of Staff, United States Air Force; letter; June 17, 1948.

${ }^{15}$ Gen. Hoyt S. Vandenberg, Chief of Staff, to Commanding General, Air Materiel Command; letter; July 2, 1948. The copy of the letter in the Air Materiel Command files has a note which indicates that the original carried the notation "OK. Symington." It appears that this letter may have been a confirmation of an earlier conversation between Generals Vandenberg and McNarney, because General McNarney began to put the plan into action several days before the date of this letter. See footnote 16 below.

${ }^{16}$ Gen. Joseph T. McNarney, Commanding General, Air Materiel Command, to Northrop Aircraft and Consolidated Vultee Aircraft; letter; June 30, 1948.

17 John K. Northrop to Gen. Joseph T. MCNarney; letter; July 9, 1948 .

${ }^{18}$ General Smith testimony, p. 70 .

19 Ibid.

20 John K. Northrop; testimony before House Armed Services Committee, Investigation of the B-36 Bomber Program, p. 276 . See footnote 21 below.

${ }^{21}$ Ibid., p. 280. These excerpts are part of the sworn testimony later recanted by Mr. Northrop in the $1980 \mathrm{KCET}$ interview. Exactly what portion of his thirty pages of testimony is included in his admitted perjury is not clear.

22 Air Materiel Command Memo, Procurement Committee, Directorate of Procurement and Industrial Planning, Comment Number 2; August 16, 1948.

23 Air Materiel Command Memo, Procurement Committee, Directorate of Procurement and Industrial Planning, Comment Number 3; August 18, 1948.

24 Ibid. Both comments by colonel schaetzel referred to an arrangement "directed" or "required" by the secretary of the Air Force. Were these references to a decision forced on Northrop by Mr. Symington, or might Colonel Schaetzel have been referring to a published Air Force order with Mr. symington's signature? For two reasons, one might tend to accept the latter, and far less sinister, explanation. First, Colonel Schaetzel apparently did not attend the July 16 Air Force/Northrop/Convair meeting, at which the subcontract was agreed upon. (See Mr. Northrop's testimony before the House Armed Services Committee, p. 283.) Second, if Colonel Schaetzel were really aware of some impropriety on the part 
of the Air Force Secretary, it seems unlikely that he would circulate such knowledge in a memo making the rounds of Air Materiel Command Headquarters. Questioned in 1983 about the decision to keep Fort Worth open, Senator Symington could not recall the specifics of the issue. He did say that it seemed, in retrospect, a military decision, likely made by uniformed officers in the Pentagon. In his 1949 testimony before the House Armed Services Committee, Mr. Symington confirmed that he was the formal approver of such orders, but that he relied almost totally on his military advisors: "There was no formal request that wasn't approved by me, and there was nothing approved by me that wasn't recommended by General Vandenberg." See House Armed Services Committee, Investigation of the B-36 Bomber Program, p. 227. For more on Mr. Symington's role as Secretary of the Air Force, see Chapter VII. 


\section{CHAPTER VI}

\section{CANCELLATION OF THE RB-49 PROGRAM}

As the fall of 1948 arrived, three separate and unrelated events took place, events that would combine to put the RB-49 program in serious jeopardy. The first was the resurgence of the B-36, the giant bomber then being developed and produced by Convair. The second involved a change of leadership in the Strategic Air Command, in which Gen. Curtis E. LeMay replaced the first SAC commander, Gen. George C. Kenney. The third and final blow to the RB-49 came not from the Air Force, but from President Truman, who imposed deep cuts in the Fiscal Year 1950 defense budget. The RB-49 might have survived any one, or even two, of these events, but the coincidence of all three proved insurmountable.

\section{Improvement of the B-36}

Like its competitor $\mathrm{xB}-35$, the $\mathrm{B}-36$ got its start before America entered World War II. The survival of Britain was in doubt, and American planners saw the possible need for a bomber capable of reaching European targets from bases in North America. Chief of the Army Air Corps Gen. H.H. Arnold explained the rationale years later, in 1949: 
So it was only normal then that I should call together the engineers in Washington, the designers, and the scientists, and say, 'Now, listen. This is 1940. We have the B-29s well started. It will come out before the war is over. But there is a next step beyond that. And, if unfortunately this war should continue beyond our expectations, it may reach a point where we have to send a bomber from Labrador or from Greenland to the interior of Germany. I want you fellows to go out now and think about an airplane, the next step beyond your B-29, something that will go ten thousand miles, something that will carry a five-ton load and be able to return to its base.' And it was the logical thing to do. It was just a natural development. .

Thus it was this "natural development" that spawned both Northrop's $\mathrm{xB}-35$ and Convair's $\mathrm{xB}-36$. Both programs proved extremely frustrating. Like the $\mathrm{xB}-35$, the $\mathrm{xB}-36$ took nearly five years to make its maiden flight, and its early flight test program was troublesome. The first commander of the Strategic Air Command, Gen. George C. Kenney, had serious misgivings about the $B-36$, even suggesting on December 12,1946 that the program be halted. ${ }^{2}$ Original performance figures gave the $B-36$ a range of just 6,500 miles, only marginally better than Boeing's B-50, a refinement of the B-29. In addition, General Kenney thought the B-36 was too slow and vulnerable to enemy attack. ${ }^{3}$

Gen. Nathan Twining, then Commander of Air Materiel Command, rejected General Kenney's recommendation, and the development of the B-36 continued. By 1948, General Twining's faith in the B-36 had been vindicated: while the huge bomber was not without its problems, it could do things that no other airplane could. It was unsurpassed in its bomb-carrying capacity: on June 30, 1948, a B-36 dropped a 
record 72,000 pounds of bombs in a test. Six months later, another B-36 dropped 84,000 pounds (nearly the entire empty gross weight of its B-49 competitor) from an altitude of 35-40,000 feet. ${ }^{4}$ Maximum altitudes--once a cause of concern to the Air Force--were also impressive: by the end of 1948, an experimental YB-36 had climbed to above 46,000 feet, well above what even the B-36's supporters had thought possible. 5

Bomb capacity and altitude were important, but the area in which the B-36 truly excelled was range. When General Kenney wanted to cancel the B-36 in 1946, the best estimates of its range were in the 6,500-mile area. In April 1948, the first production B-36 flew more than 6,900 miles, with a 10,000 pound bomb dropped at the midpoint of the mission. ${ }^{6}$ Improvements soon followed. The next month, the same B-36A flew 8,062 miles, despite a malfunctioning engine. Six months later, a B-36B flew a simulated bombing mission from Fort Worth to Hawaii, over 8,100 miles with a 10,000 pound load. ${ }^{7}$ The B-36 was thus proving itself as the only bomber capable of reaching Eurasia from bases in the united States, and returning, without relying on air refueling, which was then in its infancy.

The last remaining concern the Air Force had was speed, and even that was overcome in the fall of 1948. On october 5, Convair proposed a modification which would add four jet engines to the six propellers then powering the $\mathrm{B}-36 \mathrm{~A}$ and $\mathrm{B}-36 \mathrm{~B}$. The result: greater speed over target. 
Top speed would increase from 345 miles per hour $(B-36 A)$ and 381 miles per hour (B-36B) to 435 miles per hour for the proposed jet-assisted B-36D. The added power would also permit higher (above 45,000 feet) operation, with an increase in weight-carrying ability of almost 30,000 pounds. ${ }^{8}$

In all, the latter part of 1948 saw dramatic improvements in the B-36. Even the early $-A$ and $-B$ models could carry more bombs further than any other aircraft, and the improvements in the jet-powered B-36D promised even further advances in the future.

\section{The Return of General LeMay}

While the B-36 was proving itself to be far better than expected, another development occurred which would prove instrumental in the demise of the RB-49. Following a stint as Commander of United States Air Forces in Europe, Gen. Curtis E. LeMay was selected in October 1948 to succeed General Kenney as Commander of the Strategic Air Command. A strong believer in strategic reconnaissance, one of General LeMay's top goals was to improve the quality of SAC's reconnaissance force. ${ }^{9}$

When the RB-49 contract was let in the summer of 1948 , the Flying wing did not have much competition as a reconnaissance plane. But by the time General LeMay took over SAC in october, that had changed: the B-36, with its defensive firepower, improving range and altitude, and newly acquired speed, appeared to be a strong competitor. Further 
damaging the RB-49's prospects was yet another stretchout in delivery: RB-49, version III, which would have been the first version to offer similar range as the B-36, was now not expected to be ready for production until 1952 or 1953 (instead of the previous estimate of 1951), which would put it in direct competition with what was expected to be a superior airplane, Boeing's B-52, then in the design stage. ${ }^{10}$

Acting on General LeMay's wishes, General Cabell, Director of Intelligence, called for a conference to review, again, the requirements for strategic reconnaissance aircraft. Officers representing the Air Staff, Air Proving Ground, Air Materiel Command, and SAC assembled on November 12, 1948 and released their recommendations three days later. Based on the improvements already shown by the B-36, and based also on the projected figures for the jet-powered modification, the Board recommended the B-36 as its first choice; second choice was a reconnaissance version of Boeing's new B-47, short in range but designed to be air refuelable; another Boeing entry, the B-54 (a bloated development of the B-29/B-50 series) was a distant third choice. The RB-49 was not included at all. Major General F.H. Smith, Jr. testified to the House Armed Services Committee in 1949:

Between the summer of 1948 and the time of the reconnaissance meeting in November, a number of developments occurred which made the B-49 series look less promising in comparison with other airplanes. For one thing, the Air staff felt less confident about the early availability of the B-49 as a bomber 
Its aerodynamic design as a tailless airplane caused it to yaw and pitch . . . requiring a more precise autopilot than is needed for conventional airplanes.

It had other shortcomings, such as lack of armament. Minor problems of this sort are usual in a radically new design and undoubtedly could be overcome in time... [but] they were sufficient to cause Air Materiel Command to recommend postponing development. . $\cdot_{1}$ until further flight tests had been made.

How could the RB-49 be satisfactory in the summer of 1948, and unsatisfactory just a few months later? Part of the answer lies in shortcomings of the RB-49--the crash at Muroc, instability, short range, poor armament--but the B-36 had its share of such problems, and more. Still, much was a result of the $\mathrm{B}-36^{\prime}$ s remarkable resurgence, specifically in bomb-carrying ability, altitude, and range. As General Smith went on to explain to the House Armed Services Committee, the RB-49 wasn't bad, but the Air Force, SAC, and General Lemay felt the B-36/RB-36 was better:

The characteristics of an airplane cannot be judged on an absolute basis; they must be compared with the characteristics of other airplanes expected to be available at the same time. The shortcomings of the RB-49 in themselves did not argue against procurement of that airplane. In the summer of 1948, they seemed acceptable because the [R]B-49 did not have much competition as a reconnaissance airplane. In the fall of 1948, the B-36 had demonstrated outstanding performance capabilities and was certainly superior to the current version of the $[R] B-49$. Future versions of the $[R] B-49$ would not be available for several years, at which time they would be in competition with other models, expected to be equally good or better.

\section{Budgetary Limitations}

The third strike against the RB-49 came not from the Air Force, but rather from President Truman himself. The 
problem stemmed rot from any doubts about the RB-49, but instead reflected President Truman's desire to maintain a "pay as you go," deficit-free defense posture, especially in time of peace:

As county judge, senator, and President, I consistently kept in mind the same sort of tax philosophy. It was a pay-as-you-go program, except in emergency conditions . . . There is nothing sacred about the pay-as-you-go idea so far as I am concerned, except that it represents ${ }_{13}$ he soundest principle of financing that I know.

In 1947, the Air Force strength had stood at fortyeight combat groups. By late 1948, amid the tension caused by Soviet actions around Berlin, that number had been increased to fifty-nine, with an ultimate goal of seventy fully-equipped combat units. The contracts awarded in 1948 (including the contract to Northrop for thirty RB-49s) were geared toward supporting this seventy-group force. 14

But despite the Berlin situation, President Truman refused to support the Joint Chiefs of Staff budget proposals for Fiscal Year 1950. The Services' own estimate of their needs for FY 1950 was 23.8 billion dollars. 15 President Truman, though, imposed a ceiling of 14.4 billion dollars, or a little more than half the Services' desires. 16 clearly, the "pay-as-you-go" concept was at work. In a letter, Defense Secretary James Forrestal summed up the problem:

- . Our biggest headache at the moment, of course, is the budget. The President has set the ceiling at 14 billion 4 against the pared down requirements that we put in of 16 billion 9. I am frank to say, however, that I have the greatest sympathy for him because he is determined not to spend more than we 
make in taxes. ${ }_{17}$ He is a hard money man if ever I saw one. .

On December 9, the Service secretaries and the Joint Chiefs met with President Truman. The President listened to their arguments, but remained firm: 14.4 billion dollars was to remain as the FY 1950 defense ceiling. ${ }^{18}$ The impact on the Air Force's seventy group expansion was devastating: instead of building from fifty-nine to seventy groups in FY 1950, suddenly the Air Force had to cut eleven units, dropping from fifty-nine back to the original forty-eight groups. 19

The impact was especially felt in the Strategic Air Command. SAC's long range bombers and reconnaissance craft were expected to represent much of the previously projected increase. Now not only would that increase be forgone, but SAC would likely have to share in the cutbacks of already existing forces. Forrestal expressed his concern in a November 1948 memo, one of a series called "Points for the President" :

Throughout my recent trip to Europe I was increasingly impressed by the fact that the only balance that we have against the overwhelming manpower of the Russians, and therefore the chief deterrent to war, is the threat of the immediate retaliation with the atomic bomb. I have substantial misgivings that reduction of the potential of the Air Force in the long range bombing field might be misunderstood both by the world at large and particularly by our only enemy.

Despite reservations as to the wisdom of the budget cuts, the Air Force set to work to implement the force reductions. With the new forty-eight-group ceiling, a number 
of programs, planned or in existence, would need to be cut back. To recommend exactly where adjustments should be made, a group of top Air Force decision makers were called together. The group was called the Senior officers Board.

\section{Senior Officers Board}

The first meeting of the Senior officers Board began on December 29, 1948. There were to be only four voting members: Gen. Muir S. Fairchild, Air Force Vice Chief of Staff; General McNarney, still Commander of Air Materiel Command; Lt. Gen. Howard Craig, Deputy Chief of Staff, Materiel; and Lt. Gen. Lauris Norstad, Deputy Chief of Staff, Plans and operations. General Fairchild became ill, so General McNarney chaired the meeting. ${ }^{21}$ The main witness at this first Senior officers Board was the new SAC Commander, General LeMay, supported by members of his staff. At the meeting, he asked for the ability to restructure his force, eliminating some purchases while increasing others. His desires were simple: more and better-equipped B-36s. To buy thirty-nine additional B-36s, some as bombers and some as reconnaissance planes, and to modify (specifically, add jets tol ninety-four of the original B-36s would cost $\$ 269,761,000 .^{22}$ General LeMay explained his desires for the B-36 to the House Armed Services Committee in 1949: COMMITTEE COUNSEL: And the reason that you so advocated the procurement of these additional B-36 airplanes, will you state that briefly to this committee?

GENERAL LEMAY: I now represent the people who flew our bombers in the last war. Some of them are still 
around in the Air Force. They are the ones who are going to fly the bomber missions if you call on us again to fight. It is my job to know what they like in the way of equipment and what they can do with it. . . We have a requirements committee that is constantly making recommendations to me on equipment. They made a recommendation to me that the B-36 was the best possible airplane that we could procure to do our job, and I agreed with them, and I made that recommendation $2_{3}$ to the senior Officers Board and it was approved.

To get his $\mathrm{B}-36$ bombers and $\mathrm{RB}-36$ reconnaissance aircraft, General LeMay offered to forgo other aircraft purchases. Among the airplanes deemed expendable were Northrop's RB-49s. As General Smith explained:

General Lemay . . testified that an increase of two groups of $B-36$ bombers (at the expense of two medium [Boeing $\mathrm{B}-50$ ] bomb groups) and a strategic reconnaissance group of $\mathrm{RB}-36 \mathrm{~s}$ (in lieu of the RB-49 type) would greatly enhance his ability to launch a strategic offensive. The board approved this recommendation and recommended that the funds made available by any cancellations be devoted to implementing 2 the recommendations of the Strategic Air Command.

To raise the $\$ 269,761,000$ needed for the $B-36 / R B-36$ purchases, the first Senior officers Board recommended cancellation of six separate weapon systems involving four corporations. It should be noted that Convair suffered some loss, although far less than the others. It must also be noted that North American, not Northrop, suffered by far the heaviest losses: 25

\section{MANUFACTURER}

North American

North American

Northrop

Northrop

Kellett

Convair
AIRCRAFT

$$
\begin{array}{r}
B-45 \\
F-93 \\
R B-49 \\
C-125 \\
H-10 \\
Y T-32
\end{array}
$$

NUMBER

51

118

30

30

10

1
AMOUNT OF CANCELLATION

$$
\begin{array}{r}
\$ 105,300,000 \\
57,930,000 \\
88,500,000 \\
8,940,000 \\
6,831,000 \\
2,260,000
\end{array}
$$


On January 11, 1949, the recommendations of the Senior officers Board were implemented. A telegram from Air Materiel Command to Northrop formally cancelled the production of the RB-49:

In anticipation of receipt of formal termination notice, the contractor is directed to stop all work authorized. . with the exception of the engineering, fabrication, and flight ${ }_{6}$ test applicable to the YRB-49A airplane. .

The last part of the cancellation notice is most significant. Contrary to the claims made by reporter clete Roberts, that the planes, "each and every last one of them," were ordered scrapped by the Air Force, we can see here that the YRB-49 test program was ordered continued. On May 4, 1950, more than a year after the cancellation and just after the ground accident that destroyed the only surviving YB-49 bomber, the YRB-49 made its first flight from Hawthorne to Edwards Air Force Base ${ }^{27}$ where the Air Force intended to use it as an experimental vehicle:

This airplane will be used as a photo reconnaissance prototype. It is planned to accomplish such flight tests as are necessary to evaluate the airplane. . after which tests the airplane will be turned over to the Photographic Laboratory for testing new photographic equipment under highs speed, high altitude conditions. Total quantity-1.

\section{Epilog}

The rest of the history of the single YRB-49 is murky, much of it lost due to incomplete Air Force records after the cancellation. Following the ground accident which destroyed the sole surviving YB-49 on March 15, 1950, the sixengine YRB-49 became the last existing full-size Flying 
Wing. After its maiden flight on May 4, 1950, the YRB-49 entered flight test as planned, only to encounter stability problems similar to those which had plagued its bomber predecessors. It was flown to Ontario, California, where a stability augmentation system was to be installed. Once again, funding was apparently cut and the last of the big Flying Wings was relegated to outside storage in the grape vineyards surrounding the ontario airport. In october 1953, nearly five years after the cancellation of the RB-49 production program, Air Force crews from nearby Norton Air Force Base cut up the YRB-49 for scrap. ${ }^{29}$ The last of the large Flying Wings was gone. 


\section{Chapter VI Footnotes}

${ }^{1}$ Gen. H. H. Arnold, testimony before the House Armed Services Committee, Investigation of the B-36 Bomber Program, p. 369 .

${ }^{2}$ General Smith testimony, p. 47.

${ }^{3}$ Ibid.

${ }^{4}$ Ibid., p. 71 .

5 Ibid.

${ }^{6}$ Ibid., p. 62 .

7bid., p. 71. The mission coincided with the seventh anniversary of the attack on Pearl Harbor, and created a stir when the bomber's unannounced approach went undetected by the Hawaiian air defense system. See Meyers Jacobsen and Ray Wagner, B-36 in Action (Carrollton, Texas: Squadron/Signal Publications, 1980), p. 11.

${ }^{8}$ Ibid., p. 74. See also B-36 in Action, pp. 11, 18, 19, and Frederick A. Johnsen, Thundering Peacemaker (Tacoma, Washington: Bomber Books, 1978), pp. 3-4. There is some evidence that the touted top speed of $435 \mathrm{mph}$ was inflated, whether intentionally or not. Performance data in 1954 gave the jet-equipped D-model a top speed of between 406 and 417 mph, depending on weight. While this was still an improvement over the $381 \mathrm{mph} \mathrm{B-model,} \mathrm{and} \mathrm{the} \mathrm{even} \mathrm{slower} \mathrm{B-36A,} \mathrm{it}$ represents a less dramatic boost than was referred to in General Smith's 1949 testimony. See B-36 in Action, p. 18.

${ }^{9}$ Ibid., p. 75 .

${ }^{10}$ Ibid., p. 76 .

${ }^{11}$ Ibid., p. 75 .

${ }^{12}$ Ibid., pp. 75-76.

${ }^{13}$ President Harry S. Truman, Memoirs by Harry S. Truman, Volume Two: Years of Trial and Hope (Garden City, New York: Doubleday \& Co., 1956), p. 41.

${ }^{14}$ General Smith testimony, pp. 79-82.

${ }^{15}$ Walter Millis, ed., The Forrestal Diaries, (New York: Viking Press, 1951), p. 503. 
${ }^{16}$ Sometimes the figure used is 15 billion dollars, not 14.4 billion. The 600 million dollar difference represented raw material stockpiles which President Truman counted as part of the defense budget, but which the JCS did not. See Millis, The Forrestal Diaries, p. 498.

17 Millis, The Forrestal Diaries, p. 536. Letter to United States Representative Walter G. Andrews, December 13, 1948 .

${ }^{18}$ Ibid.

${ }^{19}$ Ibid., p. 538. See also General Smith testimony, p. 86 .

${ }^{20}$ Ibid.

${ }^{21}$ General Smith testimony, p. 83.

22 Ibid., p. 106.

${ }^{23}$ Lt. General Curtis E. LeMay, testimony before the House Armed Services Committee, Investigation of the B-36 Bomber Program, p. 146.

${ }^{24}$ General Smith testimony, p. 83.

${ }^{25}$ Lt. General Edwin S. Rawlings, testimony before House Armed Services Committee, Investigation of the B-36 Bomber Program, p. 455. While North American was the biggest loser in the January 1949 cancellations, Boeing suffered an even greater loss of business two months later. To purchase yet another batch of B-36s, a second meeting of the senior officers Board cancelled $\$ 179,937,000$ worth of contracts for 43 Boeing B-54s/RB-54s. See General Rawlings testimony, p. 456.

${ }^{26}$ Chief, Aircraft and Missiles Section, Procurement Division, Air Materiel Command, to Northrop Aircraft Inc.; telegram; January 11, 1949.

27 Anderson, Northrop: An Aeronautical History, p. 108.

${ }^{28}$ Air Materiel Command Routing and Record Sheet, January 28,1949 . The signature of the General who signed the memo is not still legible, but he was apparently chief of AMC's Procurement Division.

${ }^{29}$ Maloney, Northrop Flying Wings, p. 30. See also Anderson, Northrop: An Aeronautical History, p. 108. 
RESPONSES TO MR. NORTHROP'S STATEMENT: SENIOR AIR FORCE LEADERSHIP AND CURRENT NORTHROP MANAGEMENT

In the previous chapters, we have seen that the written historical record points toward a variety of competitive, technical, and economic considerations which worked against the procurement of the Flying Wings. But Mr. Northrop in the 1980 interview said that those factors were not the causes of the cancellation. Instead, according to Mr. Northrop and his former chairman, Mr. Millar, the cancellations grew directly from their refusal to merge their corporation with Convair, as they claimed Mr. Symington demanded. We have seen Mr. Northrop's account:

MR. NORTHROP: I got a telephone call a few days later from Mr. Symington. He said, "I am cancelling all your Flying wing aircraft." And I said, "Oh, Mr. Secretary, why?" And he said, "I've had an adverse report," and hung up. That was the last time I ever talked to him, and the last time we could ever reach him by phone or any other way.

ROBERTS: Did he give the contract to someone else?

MR. NORTHROP: He continued the construction of the B-36 by Consolidated Vultee in Fort Worth.

ROBERTS: So, in fact, the contract was taken away from you, and given to Consolidated because you had refused to merge with consolidated as you were ordered to do by the government, is that accurate?

MR. NORTHROP: That is absolutely accurate. ${ }^{1}$ 
We have also seen that in the same broadcast, Mr. Millar confirmed the hostile tone of the meeting: MR. ROBERTS: Mr. Millar, did you fear reprisal? MR. MILLAR: Yes. . . the meeting with Mr. Symington was so, shall I say, brutal. . . barefaced. - so obviously, if you will, a power play that you almost had to assume that he would be prepared to take further steps if we didn't go as good boys and go along. . . .

In my research, I have taken Mr. Northrop's and Mr. Millar's statements, and have attempted to find evidence that would either corroborate or refute them. This chapter first looks at the senior Air Force leadership of that day, to get their perspective. In gathering information for this portion, I interviewed Sen. Stuart symington, both by telephone and at his home in New Canaan, Connecticut; Gen. Curtis E. LeMay, former Commander of the Strategic Air Command and Air Force Chief of Staff, at his home in Newport Beach, California; Gen. Lauris Norstad, former Deputy Chief of Staff for Plans and operations, and the only surviving member of the 1949 Senior officers Board, by telephone from his home near Tucson, Arizona; and finally Gen. Elwood P. Quesada, former Commander of the Tactical Air Command and former chief of the Federal Aviation Administration, interviewed at the United States Air Force Academy.

In addition to the perspectives provided by the former Air Force leaders, this chapter also includes statements by the current Northrop Corporation's top executive. Thomas V. Jones, Northrop's Chairman of the Board, contacted me by telephone specifically to clarify the position of today's 
Northrop management.

Several questions form the structure of this chapter:

1. Did the meeting take place as Mr. Northrop and Mr. Millar describe?

2. Did Mr. Symington discuss a possible merger with Northrop and Convair representatives?

3. In discussing such a merger, did Mr. Symington give Mr. Northrop and Mr. Millar reason to fear reprisal if the merger was not carried out?

4. Even if Mr. Symington had wanted to cause damage to Northrop by cancelling the Flying Wing, was he in a position to do so?

5. Did Northrop and its Flying wing get a fair trial?

The answers to these questions will go a long way toward destroying some of the myths surrounding the Flying Wing's demise.

Question One: Did the meeting take place as Mr. Northrop and Mr. Millar describe?

We saw in Chapter I that Mr. Northrop described the momentous meeting this way:

The same day that General McNarney . . came to my office with that additional order for thirty-five airplanes . . Mr. Millar and I were requested to visit Mr. Symington. At that meeting, he lectured us rather lengthily on the difficulties of a Secretary for Air in keeping things in hand, and told us that he did not want to sponsor any new aircraft companies entering the business and having to be supplied with business over the years, and that he wanted us without question to merge with Consolidated Vultee, which was then operating a governmentowned plant in Fort Worth, building the B-36. . . 
After the lengthy diatribe on Mr. Symington's part, I said, "Mr. Secretary, what are the alternatives to this demand you're making of our merger with Consolidated Vultee?" And he said, "Alternatives? You'll be goddamned sorry if you don't!"

General McNarney said, "Oh, Mr. Secretary, you don't mean that the way it sounds," and Mr. Syming-
ton said, "You're damned right I do."

There is no doubt that the meeting took place. Mr. Northrop testified to it in the 1949 House Armed Services Committee hearings, as did Floyd Odlum of Convair and General F. H. Smith, Jr., who delivered the Air Force's statement. 4 But apparently Mr. Northrop's statement as to who demanded the meeting was incorrect: the person who instigated the meeting was not Mr. Symington, but Mr. Northrop himself. To work out the confusion caused by General McNarney's letter concerning movement of RB-49 production to Fort Worth, Mr. Northrop had asked for clarification. According to General Smith's testimony,

In response to General McNarney's suggestion, Consolidated held initial conferences with Northrop officials. . on July 9, 1948. On the same date Northrop notified General McNarney that in the preliminary meetings with Consolidated, several points had arisen which needed clarification . . . Early action by Air Materiel Command was requested.

Mr. Northrop followed up his letter with a verbal request for a round-table discussion. . . In response to this request, General McNarney and Gen. K. B. Wolfe of Air Materiel Command went to Los Angeles on July 15, 1948. . . . At the time of this conference, the secretary of the Air Force, Mr. symington, was on the west coast to fill a long standing engagement to be the principal speaker at a dinner. . .

Mr. Northrop, in his own 1949 testimony, confirmed that it was he who asked for the meeting: 
We suggested a meeting of the principals involved, wherein the questions concerning the production could be resolved. That meeting was held in Los Angeles on the 16 th day of July. . . .

These statements must cause at least some skepticism regarding Mr. Northrop's claim that Mr. Symington demanded the meeting, presumably so he could order the Northrop/ Convair merger. But here we see that Mr. Northrop himself asked for the meeting. If Mr. Symington really intended to improperly force Northrop to accede to a merger, would it be logical for him to wait until Mr. Northrop got around to asking to get together? Even more disturbing is the coincidence of the speaking engagement: were Mr. Symington not already committed to be on the west coast, he most likely would not have been involved at all. These facts would certainly seem to argue against any premeditated conspiracy between Mr. Symington and Convair.

In 1983, Mr. Symington could not recall the Los Angeles meeting. Thus, he did not recall who asked for the conference, and was "almost certain" it was held in his office at the Pentagon. 7

Question Two: Did Mr. Symington discuss a possible merger with Northrop and Convair representatives?

The answer to this is a probable "yes." We have already seen the testimony of General Smith in which he said that at the July 16,1948 meeting,

Mr. Odlum suggested a merger. . as the best way of combining the Northrop engineering talent with Consolidated's production know-how. The suggestion 8 seemed reasonable to the Air Force representatives. 
Since Mr. Symington was the leading "Air Force representative," at least at part of the meeting, it seems reasonable to assume he took part in the discussions. Interviewed in 1982, Senator symington could clearly recall discussing the Flying Wing with Mr. Northrop, but was not sure exactly when or where the conversation took place. A possible merger might very well have been discussed:

The Air Force Chief [General Vandenberg, Chief of Staff] wanted the B-36 and it was up to me to get it. Now you know, of course, that there was a tremendous amount of overcapacity in the industry following world War II. It was clear that many of the smaller companies would not survive. Northrop came to see me, and said that unless he received his Flying wing orders, his company would be in serious trouble. I knew at that time that the Air Force favored the B-36, built by Convair. I may very well have suggested that he merge his company with Convair, who we knew was going to get business. I may have suggested he go see Dutch Kindleberger at North American, or Bill Allen at Boeing. What I'm saying is this: I may very well have suggested Northrop talk with Convair about a merger. I'm quite certain, though, that I never would 9 have discussed such a merger with Floyd odlum.

Question Three: In discussing such a merger, did Mr. Symington give Mr. Northrop and Mr. Millar reason to fear reprisal if the merger was not carried out?

Mr. Northrop and Mr. Millar have made their statements; Senator symington has no recollection of ever saying anything that could have been construed by Mr. Northrop and Mr. Millar as a threat. But even if one were to assume he did make such a comment, there seem to be at least two possible interpretations. The first is that of Mr. Northrop and $\mathrm{Mr}$. Millar: that they were being forced to merge, against their will, with a competitor. The second 
interpretation is equally plausible, and much more innocent. Since Mr. Symington apparently knew from Mr. Northrop that his company could be in trouble without the RB-49 order, and since he knew also that Convair would be getting more business, the statement could be construed as a fair assessment of the post-war aircraft manufacturer situation: only the strongest would survive, and the likely result of Northrop's remaining small and independent would be bankruptcy

In the absence of proof, one has to look at tendencies. Would it have been out of character for Mr. Symington to have indicated that Mr. Northrop would "be goddamned sorry" if he didn't merge? Gen. Elwood P. Quesada, a long time associate of senator symington, a former head of the Federal Aviation Administration and now Board Chairman of L'Enfant Plaza complex in Washington, D.C., had this to say:

I've known senator symington a long while, and I know of a number of occasions where he, like others, could have enriched himself at the public expense. He never did, never even was interested.

At the same time, though, it would be completely in character for him to blow his top and yell at somebody, even something like the "You'll be damned sorry if you don't," remark. He's got something of a temper, you know.

Gen. Curtis Lemay painted a similar picture of Senator Symington, that of a volatile man who was inclined sometimes to act on a problem first, and think about it later:

I remember for some time a big argument was going on with the Navy about the B-36. . . The Navy had a new jet fighter then, they said it could shoot [the B-36] down... the Banshee, they called it.. and we were discussing that with symington, whether a fighter could shoot down a bomber. I said, "Yeah, 
a fighter can shoot a bomber down, sure it can. Any fighter can shoot any bomber down, if it's as fast. But it may not be conducive to long life and happiness. The only way to prove it is to put the B-36 and the Banshee up and to fight it out." So, symington then comes out with a statement that we would fight out a battle with real bullets with the Banshee and the B-36..${ }^{1}$ He was like that, things
I never could figure out.

Even accepting the possibility that Mr. Symington made a statement that implied that Northrop would regret a failure to merge, it seems to be almost certain that such a statement was not intended as a threat.

Interviewed in 1983, Senator symington called "preposterous and absurd" the idea that he would threaten a firm in an open meeting, with many others present:

If there's one thing I learned in all my years in government, it's that it's impossible to keep a secret. You've got twenty people working for you, and they each go home and tell twenty people, and pretty soon it's all over town. It may take a while, but you $2^{c a n ' t ~ k e e p ~ a ~ t h i n g ~ l i k e ~ t h a t ~ a ~}$ secret.

Still another factor which must be considered is the presence of General McNarney. A long-time aide to Gen. George Marshall, General McNarney was a man of high integrity, and a man who maintained a very formal relationship with Mr. Symington. According to senator symington, this was especially true because of a situation the previous year, when Air Force Chief of staff "Tooey" spaatz came to the Secretary of the Air Force to announce his intention to retire. General spaatz asked for Mr. Symington's opinion on a successor, but Mr. Symington declined, saying he felt it was a military decision, best left for military men. 
Together, Spaatz and Symington took the case to General Eisenhower, then advisor to the Joint Chiefs of Staff. Eisenhower studied the records of the two main candidates, Generals McNarney and Vandenberg, and chose Vandenberg, based on his strong combat record. From then on, according to Senator Symington, General McNarney maintained a distant, formal relationship, perhaps surmising that Mr. Symington was responsible for his non-selection. ${ }^{13}$

With this in mind, we see that the conference of July 16, 1948, did not contain a great many of Mr. Symington's friends: Convair representatives may have been neutral, but Northrop people blamed him (indirectly at least) for the transfer of production to Fort Worth, and his one organizational ally, General McNarney, felt that the Secretary was responsible for his passover. Does it seem logical that Mr. Symington would choose this environment to make an improper demand on Northrop?

And if for some reason he had made the demand, why would General McNarney remain silent? Even Mr. Northrop did not blame General McNarney, who supposedly said, "Mr. Secretary, you don't mean that the way it sounds," when Mr.

Symington was alleged to have made the "You'll be goddamned sorry if you don't!" comment. Are we to believe that the late General McNarney, too, was part of the conspiracy to harm Northrop? If not, wouldn't he have spoken up? Skeptics will point out that General McNarney went on to work for Convair, but that was after his retirement, almost 
two years later. Several of the people involved absolutely reject the idea that General McNarney would allow himself to be entangled in anything that even approached unethical behavior. Senator Symington, despite the coolness that developed after General McNarney was not selected as Chief of Staff, says:

General McNarney was a right arm for Gen. George Marshall during World War II, a brilliant man of spotless integrity. Any implication that for personal reasons he would be "biased" to a supplier is an insult to a great American.

General Quesada echoed the same sentiments:

Joe McNarney was the straightest of the straight arrows, a real gentleman. If the world were fair, he would have been Air Force Chief of Staff, and he should have been. But he'd been shunted into staff 5 jobs instead of command positions in World War II.

And Gen. Lauris Norstad, the sole surviving member of General McNarney's Senior Officers Board, said:

I knew him well. There was never a better disciplined officer, a more straight-laced officer than Joe McNarney. There's no skullduggery involved here.

So we can see that a merger was discussed, and $\mathrm{Mr}$. Symington most likely took part in that discussion, largely because he happened to be in the Los Angeles area at the time. We have seen that, according to his close associates, it would not be inconceivable for him to make a remark of the general tone described by Mr. Northrop and Mr. Millar. But at the same time, even were the comment made, it would appear extremely unlikely that secretary symington was threatening Northrop, for several reasons. First, that he was even there was pure coincidence, since Mr. Northrop was 
the one who asked for the meeting, at a time in which $\mathrm{Mr}$. Symington happened to be in Los Angeles. Second, the meeting was a fairly open affair with at least six (and perhaps as many as a dozen) people present, few of whom were especially friendly to Mr. Symington. Finally, improper behavior would necessarily implicate General McNarney, who not even Mr. Northrop implied was in any way unethical.

Question Four: Even if Mr. Symington had wanted to cause damage to Northrop by cancelling the Flying Wing, was he in a position to do so?

Perhaps surprisingly, the answer to this is almost certainly "no". Determination of military requirements-such as which airplane to buy--was not part of the secretary's job. According to Senator symington, when he took over the Secretary's position, he made clear to the Air Force Chief of Staff, General Spaatz, that he could offer two things to the fledgling Air Force. First was his business experience: as president of a number of corporations, including Emerson Electric, Mr. Symington could provide a unique and needed perspective to Air Force decision making. Second, Mr. Symington could push for Air Force requirements on Capitol Hill. But the determination of those requirements was the responsibility of the military Air Force Chief and his staff, not the secretary of the Air Force. ${ }^{17}$ Specifically, senator symington denied ever cancelling the Flying Wing or any other aircraft that had been recommended by the Air Force Chief: 
Not once, as Assistant Secretary of War for Air, or later as Secretary of the Air Force, did I ever cancel an aircraft that had been recommended to me by the Air Force. If any recommendation to purchase the Flying Wing had reaghed my desk, I would have approved it. None did.

Senator Symington's contention that he always approved the military-developed recommendations may seem a bit disingenuous. It certainly was not believed by at least one aircraft manufacturer, who tried to influence the secretary to buy a particular bomber in 1948. When Mr. Symington demurred, citing the fact that such a decision was not his to make, the manufacturer brought in a powerful senator to help argue his case, this time to both $\mathrm{Mr}$. Symington and General Vandenberg. It was General Vandenberg who confirmed that the decision was a military one, and that the airplane had been, and would continue to be, rejected. ${ }^{19}$ We have seen already that the procurement decision process in the Air Force moved from the bottom to the top, as in the case of the B-36: General LeMay's staff made recommendations to him, and he in turn made recommendations to the Senior officers Board. The Senior officers Board made recommendations to the Chief of Staff, with final ratification by the secretary of the Air Force. This means that even if the Secretary wanted to affect a decision, there were but two practical avenues open: first, he could modify a recommendation made to him by the Chief; second, he could try to tamper with the process further down the line, at the level of the using commmand, in this case, the Strategic Air Command. 
Two perspectives on this show that Mr. Symington apparently did neither. Gen. Lauris Norstad was Deputy Chief of Staff for Plans and Operations during Mr. Symington's tenure as Secretary; he is also the only surviving member of the 1949 Senior Officers Board which approved General LeMay's request for more B-36s in lieu of the Flying Wings. His statements support Mr. Symington completely:

Mr. Symington never pressured me or any senior officers of the Air Force. It was my position to make recommendations and I did. Generally, he accepted my recommendations. Sometimes he asked for more information. But never, never did he suggest we change our requirements, or go with a different airplane, or a different company. All of this was in my bailiwick, because my job was to develop requirements, and the B-36 was the only airplane, then or for the foreseeable 2 future, that could meet the requirements. . .

And General Norstad confirmed the bottom-up nature of the procurement process. Talking about Mr. Symington:

In no way did he ever generate requirements. Those came from 2 me, and they came to me from the using commands.

If there was no pressure on the senior officers of the Air Staff, it seems then that the using command, SAC, would be the next logical place to examine. But Gen. Curtis LeMay, then Commander of the Strategic Air Command, denies ever receiving pressure from Mr. Symington or anyone else, regarding the Flying wing or the $\mathrm{B}-36$ :

No, I got no pressure on any particular airplane. Wouldn't have paid any attention to it anyway.

Regarding why he opted for the B-36 in lieu of the Flying Wings, General LeMay indicated that it was simply that the B-36 was the only airplane that could do the job he 
needed to do:

I don't remember ever having any choice in the matter. The B-36 was it, and what we were pushing. I don't think [the Flying Wings] were even in the running. . [The B-36] wasn't the best airplane in the world, no. We did have a lot of troubles with it, trouble with the gunnery system, trouble with the engines, exhaust stacks kept burning out on it, but we were able to keep it in the air. . . . We finally hung some more jet engines on the airplane, got more altitude out of it, better performance. . . so that during its life it furnished us with a weapo $2_{3}$ system that would have done the job at the time.

Question Five: Did Northrop and its Flying Wing get an unbiased trial?

The answer is almost certainly "yes". In a 1982

interview, Senator symington indicated that not only did he have nothing against Northrop, but that in 1951, two years after the cancellation, he saved Northrop from bankruptcy:

But here's the real irony. The President in 1951 asked me to go straighten out some problems in the Reconstruction Finance corporation. Shortly after getting to the RFC, some . . RFC people came to see me with a recommendation that we call in some RFC loans Northrop had. I'm quite sure that would have bankrupted Northrop at the time. I decided instead that we should have one of our people put on the Northrop Board of Directors. I contacted Northrop, and suggested they accept James Allen on their Board. They didn't like that, but I told them it was that or we called the RFC loans. Jim Allen got on the board. Several years later, after Tom Jones took over at Northrop, those loans were repaid.

General Norstad said that in his opinion, the charge of $\mathrm{Mr}$. Northrop and Mr. Millar had

utterly no basis and I'd swear it was incorrect. . . There was no skullduggery involved. I knew 25 ll the cast of characters, and it's inconceivable.

General Quesada also disregards the claims. Asked if he did not believe Mr. Northrop's story, he responded: 
I believe Mr. Northrop was an old man, not, from what I have heard, entirely well. No, I don't believe it for an instant.

General LeMay similarly professed disbelief. While expressing some skepticism about politicians in general, he tended to attribute the problems to a clash of personalities:

Well, I'm kind of a pessimistic guy: all these politicians have a lower order of moral value than I think they should have but I don't think this would have been tried by anyone. . .

I don't believe any of it. Mr. Northrop, maybe he did believe it, but I don't think anybody gets mad at any particular company that's got something to sell to the armed services. You may not like what they sell, and you don't buy it, but to go and be vindictive about it after you've refused their product, no. You've too many other things to do to start fiddling around with that. You've got too much to think about with the successful guy, to make sure he gets out a product that meets your expectations. . .

There may have been hard feelings between Northrop and symington. I could understand that. Symington wasn't the most likeable guy in the world. $\cdot 27$. I never knew exactly what he was thinking. . . .

\section{Comments of Current Northrop Management}

We have seen the statements of the Air Force leaders involved in the cancellation decision. Those statements unanimously tend to support Mr. Symington's position, and to refute the allegations of Mr. Northrop and Mr. Millar.

Skeptics will point out that such solidarity among the Air Force participants may not be altogether surprising. After all, the reputation of the organization to which all of these men have devoted the major part of their lives was under fire. Wouldn't it be possible, one might ask, for these men--either together or separately, consciously or subconsciously--to distort the circumstances surrounding the 
Flying Wing cancellation?

In consideration of these arguments, I tried on a number of occasions to elicit a response from officials of today's Northrop Corporation. My efforts were, for a long time, unsuccessful: even people who had helped me on previous projects were unable to cooperate on the Flying wing story.

Then, shortly before the completion of this dissertation, I was contacted by Mr. Thomas V. Jones, past President and now Chairman of the Board of Northrop Corporation. Mr. Jones explained that he had instructed Northrop employees to refrain from comment because he believed that none of his current people could possibly know the real truth behind the 1949 cancellation. Mr. Jones explained that, in his experience, any cancellation brings forth strong emotional reactions in those people associated with the terminated project. The flying wings were certainly no exception, and Mr. Jones did not want his people making public statements based on such emotionally-charged beliefs. He went on to point out that no one currently in his firm, himself included, is in a position to comment on the specifics of Mr. Northrop's charge:

This was in the past, and none of us now involved in the Corporation were there. . . I have no direct knowledge, nor do any of our people have any knowledge, of what caused the cancellation.

But if Mr. Jones has no specific knowledge of the circumstances surrounding the cancellation thirty-five years ago, he does have strong feelings about the man accused by 
his firm's founder. According to Mr. Jones, he has never had any reason to doubt the integrity of stuart symington, despite Mr. Northrop's allegations:

I have been a friend, a close friend, of stu symington for a long time. Stu's record stands on its own. He has always been upstanding and fair in his dealings with us, and I have no reason to believe he wasn't upstanding and fair in this [the Flying wing] case. I would serve as a character witness for him any day, but as far as the specifics of [the cancellation] are concerned, I can give no testimony. Or, rather, I guess you'd say my testimony would be inadmissable. I have spent a lot of time thinking how I could do something to ease the hurt that this thing has gaused stu, but I really don't know what I can do.

\section{$\underline{\text { Summary }}$}

Like any investigator, one has to assess two factors: motive and opportunity. Did Mr. Symington have the motive to cancel the thirty RB-49s? And if he did, was it in his power to do so?

It seems that the answer to both questions is "no". As far as motive, no one will probably ever satisfy the backers of John Northrop that there was not some arrangement, some under-the-table deal, between Mr. Symington and Convair. Mr. Northrop's backers will point to the alleged threat and see not a burst of temper, but a deeper and far more sinister conspiracy. The opinions of men like Generals Lemay, Norstad, and Quesada--even with the support offered by Northrop's Thomas Jones--will not convince skeptics that Mr. Symington is not guilty.

But the second half of the problem, that of opportunity, must make the most skeptical observer pause. Not only 
does Senator Symington claim that he let military men make military decisions, but his statement is backed up by all the military men who were most involved in those decisions.

At the House Armed Services Committee hearings in 1949, Mr. Symington responded to a Committee member who had made charges of corruption, while at the same time making full use of Congressional immunity:

. . It did not make any difference to the Air Force, or to me about the attacks which have been made against our intelligence. It is very possible that we might have bought this airplane [the B-36], and I believe in it, and been wrong, but when people say that the entire High Command of the Air Force is dishonest--and if that is true, it means a mass conspiracy or ngthing--I take very bitter exception to that. . .

The situation is the same today. To disbelieve Senator symington is to accept the idea that the whole top leadership of the Air Force at that time was either hoodwinked by a corrupt few, or all involved in a conspiracy to boost Convair at Northrop's expense. If one does not accept one of those premises, and the additional premise that the surviving leaders are still carrying on the deception, one has to harbor serious doubts about Mr. Northrop's interpretation of the cancellation. 


\section{Chapter VII Footnotes}

1 "The Flying Wing--What Happened to It?" There are a few problems here. First, Mr. Northrop said he got the call cancelling the Wings "a few days" after he turned down Convair's merger offer. But we know from testimony before the 1949 House Armed Services Committee by Major General F.H. Smith, Jr., Mr. Northrop, and others that Northrop declined to merge on July 16, 1948, preferring the subcontracting arrangement for building the RB-49 at Fort Worth. But the cancellation occurred in January of 1949, six months later. The passing of six months, not just a "few days," would seem to blunt the cause-and-effect relationship between the merger breakdown and the cancellation suggested by Mr. Northrop.

Also, Mr. Northrop says he could never again contact Secretary Symington. In a May 25, 1983 letter to the author, Mr. Symington wrote, "That is absurd. I was always available to the head of any aviation company." Later in this chapter we will see where Mr. Symington, as head of the Reconstruction Finance Corporation, contacted Northrop Aircraft Corporation in 1951. In a 1983 interview, Mr. Symington believed that he spoke then with Mr. Northrop himself, but could not recall that with certainty.

$$
\begin{aligned}
& 2 \text { Ibid. } \\
& { }^{3} \text { Ibid. }
\end{aligned}
$$

${ }^{4}$ General Smith testimony, pp. 69-70; John K. Northrop testimony, pp. 281-283; Floyd B. Odlum, testimony before House Armed Services Committee, Investigation of the B-36 Bomber Program, pp. 625-626.

${ }^{5}$ General Smith testimony, pp. 69-70.

${ }^{6}$ John K. Northrop testimony, p. 277.

${ }^{7}$ Senator stuart symington to the author; letter; May 20, 1983.

${ }^{8}$ General Smith testimony, p. 70 .

${ }^{9}$ Senator Stuart Symington; telephone interview; November 17, 1982. On October 25, 1982, Senator Symington had been contacted by the Acting Director of the National Air and Space Museum (NASM), who had asked for the Senator's comments on a section of a book scheduled to be published by the Museum. Since the proposed text tended to support Mr. Northrop's charges (e.g., "According to Jack Northrop, considerable pressure was brought to bear on him by symington to merge with Convair."), Senator symington responded 
vigorously and quickly. In a November 4 letter (copies of which went to current Northrop Chairman Thomas V. Jones and to the author), he challenged Mr. Northrop's recollections, and criticized the NASM for believing them. NASM subsequently changed the text: see followup letter, Senator Symington to $\mathrm{Mr}$. Walter Boyne, Acting Director, National Air and Space Museum; January 7, 1983.

${ }^{10}$ Gen. Elwood P. Quesada (USAF, Retired), interviewed by the author at the United States Air Force Academy, Colorado; April 7, 1983.

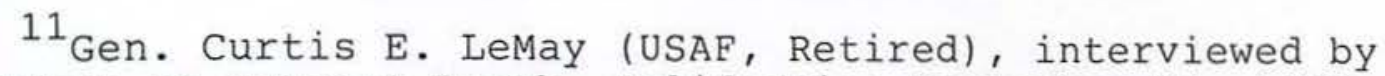
the author at Newport Beach, California; September 29, 1982.

${ }^{12}$ Senator stuart symington, interviewed by the author at New Canaan, Connecticut; June 6, 1983.

${ }^{13}$ Ibid.

${ }^{14}$ Senator Symington letter, May 20, 1983.

${ }^{15}$ General Quesada interview.

${ }^{16}$ Gen. Lauris Norstad (USAF, Retired), telephone interview; January 31, 1983.

17 Senator symington interview.

${ }^{18}$ Senator Symington telephone interview. See also his letter to Mr. Boyne, November 4, 1982.

${ }^{19}$ Senator symington interview. He would not permit the disgruntled manufacturer to be identified in this dissertation, except to say that it was not Mr. Northrop.

${ }^{20}$ General Norstad telephone interview.

${ }^{21}$ Ibid.

${ }^{22}$ General LeMay interview.

${ }^{23}$ Ibid.

24 Senator symington telephone interview. See also his letter to Mr. Boyne, November 4, 1982.

${ }^{25}$ General Norstad telephone interview.

${ }^{26}$ General Quesada interview.

27 General LeMay interview. 
${ }^{28}$ Thomas V. Jones, Chairman of the Board of Northrop corporation, telephone interview; November 4, 1983.

29 Ibid.

${ }^{30}$ Secretary of the Air Force stuart symington, testimony before House Armed Services Committee, Investigation of the B-36 Bomber Program, p. 242 . 


\section{CHAPTER VIII}

\section{TECHNICAL PERFORMANCE OF THE FLYING WINGS:}

THE AIR FORCE PERSPECTIVE

We have seen, then, that political chicanery was apparently not a significant factor in the demise of the Flying wing. Rather, the decision to cancel the thirty RB-49s resulted largely from the interaction of three developments, all in late 1948: the dramatic improvement of the competing B-36, the arrival of General LeMay as Commander of SAC, and President Truman's slashing of the Fiscal Year 1950 defense budget.

The significance of these three factors should not be especially controversial. The B-36 proved itself throughout the 1950's as SAC's first-line bomber, until finally supplanted by the B-52 in early 1959. ${ }^{1}$ It was far from a perfect aircraft, but as General Lemay pointed out earlier, it would have done the job at the time. Likewise, the effect of General LeMay's arrival at SAC is clear: far more than his predecessor, General Kenney, he believed in the B-36, and was willing to give up other systems, like the RB-49, to get it. Finally, the effect of President Truman's budget cuts is undeniable: instead of continuing its buildup from forty-eight through fifty-nine to seventy groups, the newly established Air Force had to reverse course, dropping 
back to forty-eight combat units. The airplanes that would have provided the backbone of the enlarged force became expendable.

There exists, however, a fourth dimension to the problem, perhaps not as significant as the three main factors, but far more controversial. That dimension concerns the technical performance of the Flying Wing. Was it a safe, effective aircraft design, capable of playing a useful role in America's strategic deterrent force? or was the Flying wing an unproven experiment, hazardous and not very useful, and unfit for routine operation?

To answer these questions from the Air Force's perspective, I went to the experts. For questions concerning aircraft stability and flying characteristics, the two primary Air Force test pilots for the YB-49 were most helpful. On questions of utility--i.e., could the Flying wings do the jobs that needed to be done?--General LeMay's insights were most informative. The beliefs and comments of these men go a long way toward explaining more of the real reasons for the cancellation of the Flying wing.

\section{Stability and Flight Characteristics}

No aspect of the Flying Wing story has generated more disagreement and contention than the question of the aircraft's stability. We have seen, for example, that while the Northrop people rated the stall characteristics of the YB-49 acceptable, at least one of the Air Force pilots who died in the 1948 crash was reluctant to even attempt the 
stalls scheduled on the day of the fatal accident.

Not surprisingly, John Northrop was convinced of the stability of the Flying Wing bombers. In a May, 1947 speech before the Royal Aeronautical Society, he said:

The second basic requirement is that the all-wing aeroplane be designed to have sufficient stability and controllability for practical operation as a military or commercial aeroplane. We believe this requirement has been fully met by hundreds of flights completed with this type, and we are fully convinced of its practicability.

Northrop's engineers were equally convinced of the Flying Wing's stability. D.G. McNeal, who by 1980 was Northrop's Advanced Aircraft Production Group manager, said of his involvement with the Wing: "We believed in it. . . No questions." ${ }^{3}$ Hugo R. Pink, later manager of Northrop's Test and Evaluation Group, was more reserved, but still confident:

The airplane needed a stability augmenter, and one was being developed and was quite successful before the program was cancelled. So the problem the airplane had, had been solved. And, of course, with the equipment we have today, it would be "duck soup.

It was not only the engineers at Northrop who believed in the Flying Wing's performance: Northrop's test pilot, Max Stanley, was a believer as well. For KCET reporter Roberts, Mr. Stanley outlined his opinions about the Flying Wing:

I flew the Flying Wing, both the $\mathrm{B}-35$ and the $\mathrm{B}-49$, from the first flight of each airplane through its entire program and I felt that the airplanes could be described as normal airplanes . . no special skills were needed, and I thought it was just a very fine flying machine. . :

The airplane was somewhat deficient in directional stability. However, the Minneapolis-Honeywell people developed what we called "Little Herbert", 

a stability augmentation system, that essentially
corrected this problem. . .

So the picture painted by the Northrop people is one of a generally acceptable aircraft with only minor stability problems, and even those were solved by the "Little Herbert" system. But a study of the Air Force pilots' opinions will provide a very different viewpoint.

\section{The Air Force Perspective}

Retired Brig. Gen. Robert L. Cardenas was the primary Air Force test pilot throughout most of the Flying wing bomber development. He had great affection for the YB-49, and great respect for Mr. Northrop's genius, although the YB-49 has continued to affect his life in ways not always positive. In a 1983 letter to the author, General Cardenas wrote:

I was the Air Force test pilot on the $\mathrm{XB}-35$ and the YB-49, as well as the forerunner, the N-9M. I have also been hounded and badgered by dozens of magazine, book, and history writers for ever 30 years, who have all tried to unravel the "Wing" mystery. They have all had an axe to grind, some pro-Northrop, some pro-civilian government.

What did General Cardenas think about the stability of the YB-49? In the KCET-TV interview, he told Mr. Roberts:

I've got to make clear that I never said it was unstable. It was marginally stable--stable, not unstable--about the vertical axis, or yaw, and about the lateral axis, or pitch.

What about the Northrop contention that a stability augmentation device had already solved those problems? First, "Little Herbert" only took care of the yaw problems, not the tendency to pitch up and down. 8 Further, 
"Little Herbert" was too primitive; better systems needed to be developed:

The $R \& D$ [research and development] program would have had to be oriented towards the development of what now exists, digital flight control, "flyby-wire", which was not capable of being developed at that time. In other words, Mr. Northrop had a beautiful concept that wags probably twenty years ahead of its time. . .

So, General Cardenas appears to side with Northrop's Mr. Pink, who said that with today's equipment, the solving of the YB-49's stability problem would be "duck soup". But the point is really moot: to critique a 1949 decision, using information based on aeronautical developments of the 1970's, is a pointless exercise. As General Cardenas pointed out in his 1983 letter:

I must also remind you that this was a decade. . . that, pushed to the wall by World War II, had taken us from low sub-sonic propeller aircraft to jets to super-sonic rocket aircraft--all in ten years! Put yourself in . . . that timeframe when we had the engines, the airframes, and the guts to fly all those products of a beautiful era--but no electronic "fly-by-wire" flight control systems! Today the [General Dynamics] F-16 was designed unstable to allow it to jerk square corners, but it has the type of confrol system in the $80^{\prime} \mathrm{s}$ that we needed in the 40 's.

\section{Another Pilot's View}

In April 1949, three months after the cancellation of the RB-49 order, then-Major Cardenas was replaced as the Air Force's chief Flying Wing pilot. The new pilot, also an Air Force major, was Russ Schleeh, who had been the eyewitness to the first YB-49 crash less than a year before. ${ }^{11}$ Then-Major Schleeh remained the chief YB-49 test pilot 
until he was badly injured in the crash of the only remaining YB-49 on March 15, 1950. Like General Cardenas, Colonel Schleeh was a strong backer of the Flying wing, despite its problems :

There is no question that the Flying wing . . . was a tremendous accomplishment and was responsible for many firsts. I think it was most unfortunate that the B-49 program was not kept as a development program untif its numerous problems could have been resolved.

What, according to Colonel Schleeh, were the "numerous problems" that needed to be solved? First, and most important, was stability. In the KCET-TV interview, colonel Schleeh's comments on stability were brief: "From a stability standpoint, it still needed further development."13

In a 1983 interview, Colonel Schleeh elaborated:

In rough air, because it was so short-coupled, any kind of gust would make the nose pitch way up, or way down. A modern stability augmenter would have taken care of that, but "Little Herbert" only controlled some of the yaw, none of the pitch. It prob$a b l y$ wasn't dangerous, just real uncomfortable.

More serious problems affected the YB-49 in stalls:

I never did an official stall program, just one or two to satisfy my curiosity. But a stall was not a pleasant maneuver, and you ran into all kinds of problems. Because it had no vertical surfaces, it would fall off to one side or the other as you approached the stall. As you'd go sideways, at about 40 degrees of crossflow, it would then whip over into a spin, which itself was a terrific little surprise. 15. . It was not an acceptable airplane, period. ${ }^{15^{\circ}}$

From the standpoint of stability and performance, then, it appears that both Air Force pilots harbored serious doubts about the YB-49, and that those doubts were never resolved. Both pilots are of the opinion that, given enough 
time and money, the problems could have been solved. But as to how much time, how much money would have been needed, no one can ever know. And had the stability problems been solved, would the B-49 series have been successful? Colonel Schleeh thinks not:

Probably most of the B-49's deficiencies could have been corrected; but even so, it is my opinion that it would not have been competitive with the jet bombers of that period. . . . The aerodynamics of the YB-49, which were basically those of a $400 \mathrm{mph}$ airplane designed for piston engine performance, could not compete with the aerodynamics gf an aircraft designed for jet-age performance.

\section{Another Debate: Performance as a Bombing Platform}

As with the issue of stability, the performance of the Flying wing as a bomber is a controversial issue. We saw in Chapter IV that when flown in competition with the B-29, bomb runs took four times as long with the YB-49, and accuracy was only half as good. Why, then, did reporter clete Roberts say that the YB-49 had proven itself as the successor to the B-29? Max Stanley backed up the claim that the YB-49 had been deemed by the Air Force to be a suitable bomber:

I think when you talk about the airplane being a suitable bombing platform, you should keep in mind that it was subjected to a very intense series of tests to determine its suitability as a bombing platform. It was flown by the Northrop pilots and the military pilots and the conclusion was that it 17 was a suitable bombing platform, it was acceptable.

But once again, the Air Force viewpoint is different. General Cardenas flew the first Air Force bomb runs with the YB-49 in late 1948; his bombardier was a Major Williams, who 
gave this account of the first tests, all done without an autopilot:

An experienced bombardier who has dropped a great deal of bombs from this airplane would have a very difficult time making a satisfactory bomb run in less than four minutes. On no two occasions were the altitude and airspeed constant during the bombing runs. It is impossible to keep the bubbles on the bombsight level, nor is it possible to synchronize the rate and turn knobs due to the yawing and pitching of the aircraft. On several occasions the bombs were released while the airplane was in a skid and the... error [was] approximately 3,000 feet.

His phraseology may have been awkward, but Major Williams certainly got his point across. He went on to explain that the B-29 drops under identical conditions were twice as accurate, while requiring only about one-fourth the time on the bomb run. The pilot, Major Cardenas, went on to make five specific recommendations, all of them involving significant changes to the aircraft. The first change recommended by Major Cardenas involved installation of a "satisfactory autopilot."19

So "Little Herbert" was installed. A new series of tests to evaluate the YB-49's bombing ability was conducted in April and June 1949, by which time Major Cardenas had been replaced as chief test pilot by Major Schleeh:

During the months of April and June in 1949, I flew the airplane eleven times, evaluating the aircraft as a bombing platform both with and without the 20 autopilot. The bombing results were very poor.

While "Little Herbert" had helped the yawing behavior, the YB-49 still had its problem of pitching up and down. This was exacerbated by the tendency of the bombs, shown 
clearly in photos taken from a chase plane, to themselves pitch and tumble before leaving the bomb bay. ${ }^{21}$ Exactly what caused the poor accuracy remained a mystery to colonel schleeh:

I never really knew what exactly caused the inaccuracy: Normally, you get better accuracy with an autopilot than you do by flying manually, but not in this case: We could bomb 2 manually as well as we could with the autopilot.

But what of Max Stanley's claim that after intensive tests, the Air Force declared the YB-49 an "acceptable" bombing platform? None of the Air Force records I could locate supported this contention: in no case was the YB-49 ever deemed acceptable in its then-current configuration. Colonel Schleeh, when asked about the YB-49's acceptability as a bomber, was adamant:

I never said it was acceptable, and none of us who flew bombers and knew bombing ever said it was an acceptable bombing platform. You could drop a bomb with it, but it wasn't nȩarly as good as the other airplanes of that day.

\section{Another Perspective: Performance from the User's point of View}

When General LeMay assessed the Strategic Air Command's strength in late 1948, he saw that existing war plans relied heavily on forward staging bases: the relatively short ranges of the B-29 and B-50 left no other choice. But he was reluctant to continue to rely on the foreign bases, for at least two reasons. First, foreign leaders could always deny SAC permission to use the facilities. Second, the closer the bases were to the Soviet Union, the 
more vulnerable they were to attack. ${ }^{24}$

Thus, General LeMay started to restructure SAC based on a single, primary principle: "the fundamental goal of the Air Force should be the creation of a strategic atomic striking force capable of striking any target in Eurasia from bases in the United States and returning to the points of takeoff."25 Interviewed in 1982, General LeMay reaffirmed his rationale:

Well, our most likely enemy was the Soviet Union. As I remember, this was before we had NATO so our possible bases were limited, or really unknown, so we wouldn't know what we might have. We might have had to go there from here. Anyway, we needed as long-ranged an airplane as we could get. . . .2

Once this line of reasoning had been accepted within SAC, all hope for the Flying Wing was gone. There were only two ways to get the range General LeMay wanted. The first was to build the range into the airplane, by including cavernous fuel tanks in the wings and fuselage; this was the principle used in the B-36. The second method, just becoming practical in the years around 1950, involved aerial refueling, in which a "tanker" aircraft would replenish the bomber's fuel supply in flight; this was the principle behind Boeing's B-47, and virtually every other military aircraft since.

But the Flying Wing was incapable of utilizing either approach. With an empty weight only a bit more than half that of the B-36, it was too small to compete with the B-36 in self-contained fuel. It had been designed before air refueling was practical, so it could not compete with the 
short-ranged but refuelable B-47. Even had it been possible to add air refueling capability, the B-49's tendency to pitch up and down would have made it an unlikely prospect for the delicate duet which needs to take place between a refueling tanker and bomber.

Interviewed in 1982, General LeMay confirmed that all these factors worked against the B-49 series. He similarly dismissed the current comments that the Wing's shape makes it an ideal "stealth" airplane, since the absence of sharp corners and vertical surfaces reduce the reflection of radar energy: at that time, he said, the generally accepted counter to radar was to fly higher. Only after the downing of Gary Powers' U-2 in 1960 did the strategy of "the higher, the better" come into doubt. In addition,

looking back on it now, this thing had control problems, and they said it had to be a thick wing, so we would never have gotten the performance out of it. We'd gone to thick wings before. . . We never would have 2 got supersonic with an airplane of that sort. . .

Looking back, did he, like the test pilots, wish that the program had been kept alive? No, not really:

of course, you've got to go back and try to put yourself into what we knew, what the state of the art was at the time... but I don't think it [the now. 28 lation] was a bad decision even looking at it

\section{Conclusion}

It is to be expected that the Air Force participants in the Flying wing story have a much different perspective than their Northrop counterparts. But two things are clear. 
The first is that the Flying wing has to be viewed as a complete system. To say, as the Northrop people do, that the YB-49 was a great airplane except for the stability problem is a bit like saying that the mythical Icarus was a great flier, except for this minor difficulty with overheating. A similar situation exists with the wing's capacity as a bomber. An otherwise great aviation achievement appears to have been hampered by practical, basic considerations: no one wanted a bomber that couldn't bomb, or one that couldn't reach its targets.

The second point that seems clear, though, is that the Air Force people involved in the Flying wing project shared the affection and pride of their Northrop associates. While General Cardenas and Colonel Schleeh feel strongly that the YB-49 was in no way ready for full-scale production, both men expressed regret that the developmental test program was halted. General Cardenas, who himself tended to believe Mr. Northrop's charges, expressed a fatalistic trust that the Flying wing will return:

What's done is done, and it should remain done. Why resurrect old ghosts? Let new technology and new aircraft design ${ }_{2}$ grove the point of efficacy of Wing-type aircraft. 


\section{Chapter VIII Footnotes}

${ }^{1}$ Development of the Strategic Air Command, p. 77.

${ }^{2}$ John K. Northrop, "The Development of All-Wing Aircraft"; 35 th Wilbur Wright Memorial Lecture to the Royal Aeronautical Society; May 29, 1947.

3 "The Flying Wing--What Happened to It?"

${ }^{4}$ Ibid.

${ }^{5}$ Ibid.

${ }^{6}$ Robert L. Cardenas, Brigadier General, USAF, (Retired), to the author; letter; undated (1983), p. 1.

7 "The Flying Wing--What Happened to It?" In his 1983 letter, General Cardenas elaborated on the technical difference between "marginally stable" and "unstable". Attempts to fly a given course in the $\mathrm{YB}-49$ resulted in a continuous series of corrections, each one generally smaller than the last, but never was the correct course achieved and maintained; this he referred to as "marginally stable". Were the YB-49 "unstable", the attempts to fly a given course would have resulted in ever-increasing errors, and no course could be even approximate $\overline{l y}$ followed.

${ }^{8}$ R.E. Schleeh, telephone interview, July 20, 1983. Hereafter referred to as the Schleeh interview.

9 "The Flying Wing--What Happened to It?"

${ }^{10}$ Cardenas letter, p. 1.

${ }^{11}$ Exactly what instigated the change is unclear. In his 1983 letter to the author, General Cardenas said that he was replaced because the Flight Test Center commander was "being pressured by officials in Washington to get opinions of another pilot." But his replacement, Colonel Schleeh, thought the pressure had at least originated within Northrop: "General Albert Boyd, who was Chief of the Flight Test Division, called me in one day and said I had no choice in the following matter. Someone who had no prior association with the program was needed to continue the flight test program on the YB-49. Apparently a point was made to General Boyd by someone in the Northrop Company that the Air Force's flight test people may have had some prejudice against the $\mathrm{B}-49$, and the Northrop Company would like to have a new pilot who had not been associated previously with the program." R.E. Schleeh to E.T. Wooldridge, National Air and Space Museum; letter; November 24, 1982, p. 1. 
${ }^{12}$ Schleeh letter, p. 2.

13 "The Flying Wing--What Happened to It?"

${ }^{14}$ Schleeh interview. General Cardenas made a similar point in his 1983 letter, saying that the YB-49's oscillations "did not dampen in turbulent air."

${ }^{15}$ Ibid.

${ }^{16}$ Schleeh letter, p. 2 .

17 "The Flying Wing--What Happened to It?"

${ }^{18}$ Major Williams, YB-49 bombardier, quoted in an unsigned memo from the Aircraft Branch, DCS/Materiel, to Brigadier General D.L. Putt, Director of Research and Development; November 8, 1948 .

${ }^{19}$ Major R.L. Cardenas, Report MCRFT-2182, Subject:

"Bombing Evaluation: Comparison Between Manually Controlled B-29 and YB-49 Aircraft"; December 3, 1948. Report quoted in General Cardenas' undated letter to the author, 1983, p. 2 .

${ }^{20}$ Schleeh letter, p. 1.

${ }^{21}$ Ibid.

${ }^{22}$ Schleeh interview.

${ }^{23}$ Ibid. See also Schleeh letter, p. 1.

24 Borowski, A Hollow Threat, pp. 151-154.

${ }^{25}$ Ibid., p. 151.

${ }^{26}$ Lemay interview.

27 Ibid.

${ }^{28}$ Ibid.

${ }^{29}$ Cardenas letter, p. 5 . 
CHAPTER IX

"THE FLYING WING--WHAT HAPPENED TO IT?":

A CRITICAL REVIEW

In this chapter, I will analyze essential portions of the KCET-TV documentary "The Flying Wing--What Happened to It?" in an attempt to clarify certain aspects of the cancellation decision. In so doing, I am returning to the origin of my own involvement, because it was this documentary which sparked my study of the entire Flying wing program.

When "The Flying Wing--What Happened to It?" was aired in December, 1980, I was a staff officer in the Strategic Air Command, working on a number of bomber improvement programs, most involving the aging $\mathrm{B}-52$. The show immediately captured my attention: if Mr. Northrop, Mr. Millar and Mr. Roberts were right (as I then believed they were), a corrupt and unethical decision had apparently shaped the course of aviation development, especially bomber development, for perhaps the rest of the century. Certainly the charges deserved to be explored more fully than could be done in a brief half-hour documentary. I believed then that a deeper investigation, especially one that looked at the Air Force side of the controversy, would prove worthwhile.

That, then, was the context in which this investigation was begun. Obviously, my findings as detailed in the 
previous chapters have led me to conclude that my original beliefs were wrong. In reaching that conclusion, I have also come to believe that the KCET documentary was exceptionally incomplete and inaccurate. Some of the inaccuracies were errors of omission: for example, Mr. Roberts neglected to even mention the devastating effects of President Truman's budget cuts, nor did he address the improvement of the competing B-36. Also not discussed were the meetings of the Senior Officers Board just prior to the cancellation, and the desire of SAC and its Commander, General LeMay, to acquire the B-36. Other negative aspects of the Flying Wing, like the Forbes/Edwards crash, and the YB-49's short range, and its doubtful in-flight stability, were either glossed over or not mentioned at all.

Other inaccuracies in the documentary clearly grew from the frailty of human memory. Some errors were not terribly significant: for example, Mr. Northrop forcefully described getting the order for thirty-five airplanes, but the order was really for thirty. He also referred to a fatal crash in the B-35 program, but the only such crash of the full-size Wings involved not the B-35 but the Forbes/ Edwards YB-49. In other areas, though, the effects of Mr. Northrop's apparently flawed recollections are more important: for example, we have seen his claim that the fateful July 1948 meeting was ordered by the Air Force, while the records show convincingly that the instigator of the meeting was Mr. Northrop himself. 
If the only errors in "The Flying Wing--What Happened to It?" were the aforementioned flaws of omission and memory, one could probably not be too critical. After all, Mr. Roberts closed his "exposé" with something of a disclaimer, acknowledging that "one has the feeling that only the surface has been scratched in the story of the B-49 'Flying Wing." 1 But there are other flaws in the documentary, flaws far more serious than the omissions and misrecollections cited above. The purpose of this chapter is to use several of the more dubious statements in the KCET show as a framework for spotlighting some of the misconceptions about the whole Flying wing situation.

\section{"Editorial Fairness" and Senator Symington's Real Response}

In "The Flying Wing--What Happened to It?" it appeared that Senator symington was offered a chance to make an oncamera rebuttal to the charges against him, and that he elected not to do so. In explaining the Senator's nonparticipation, KCET showed an exceptionally unflattering photograph of the Senator, while Mr. Roberts narrated the following:

The villain in the death and destruction of the B-49 Flying Wing, according to John Northrop and Richard Millar, would be the then-secretary of the Air Force Stuart symington. Editorial fairness demands that Mr. Symington tell his side of the story at this time. We invited him to do so. Speaking to us only through his secretary, the former Air Force civilian chief said that he 'never did that sort of thing,' and declined to appear in this report. 
But did he really decline to appear? According to senator symington, he was never asked. In a 1982 telephone interview, he explained that while he then lived in New Canaan, Connecticut, he still maintained a Washington, D.C. office, staffed by his long-time secretary. According to Senator Symington, his secretary received a call from california asking for his comment on Mr. Northrop's allegations regarding the Flying wing cancellation. She apparently replied that "the Senator never did that sort of thing," but would get a message to him. But the message seemed unimportant to Senator Symington, so he disregarded it:

I live in New Canaan, Connecticut. I keep an office in New York, and this one in Washington, but I'm rarely here. Somebody from California called, but the message didn't make any sense to me. I was a Senator for twenty-four years: weird messageş come in all the time. I never returned the call.

Thus, what may simply have been a secretary's loyal defense of her long-time boss was represented as an unwillingness on the part of the Senator to respond. The viewer was left with the clear impression that Senator symington was either afraid or unwilling to risk a confrontation with his accusers. But that was apparently not the case: in a later interview, he confirmed that he was not even aware of Mr. Northrop's charges until long after the KCET show was aired. ${ }^{4}$

\section{$\frac{\text { The Purported Destruction of "Every Last }}{\text { One" of the Flying Wings }}$}

One aspect of the cancellation is pointed to by Northrop supporters, more than any other, to "prove" the Air 
Force's vindictiveness: the complete destruction of all the Flying Wings supposedly ordered by the Air Force. Reporter clete Roberts gave new voice to the charges in the KCET broadcast:

- . [S] uddenly the contracts for the Flying wings were cancelled. The aircraft themselves, every last one of them, were ordered destroyed, and the order came from the U.S. government. And they were des-
troyed, each and every one of them.

The simple fact is that Mr. Roberts was wrong. True, orders were given to scrap most of the planes at the Hawthorne plant, but even that permitted two of the giant Wings to survive. We have seen that the surviving YB-49 continued to fly until it crashed on March 15, 1950, more than a year after the cancellation; we have seen also that the lone YRB-49 did not make its first flight until May 4, 1950, and that it survived until late 1953, when it was apparently scrapped as an abandoned derelict at ontario, California.

Mr. Millar gave a similar, but somewhat more accurate, account. Note that he did not say that all the wings were ordered destroyed, only those seven still on the Northrop ramp:

As part of the cancellation, instructions were issued to destroy the seven airplanes on the apron of the plant. Those airplanes were destroyed in front of the employees and everybody who had their heart and soul in them. No reason was given. . . No explanation was forthcoming ás to why they didn't save at least one or two. . . .

But of course two--the YB-49 and YRB-49--were saved. And while it was unfortunate that the seven airplanes were 
scrapped in the presence of those who had built them, was there a better alternative? On February 25, 1949, the Air Force estimated that the dismantling of the seven planes still at Northrop would save $\$ 7,500,000$, compared to the cost of making them flyable. ${ }^{7}$ Should the Air Force have spent those millions to make the wings flyable, so they could be dismantled at some other location? Rather obviously, the decision was an economic one: the Air Force could not justify spending any more money (beyond that which was to be spent on the continued tests of the YB-49 and YRB-49) on a project that had finally reached a dead end.

\section{Museum Pieces}

In his documentary, Mr. Roberts pointed out that the Air Force's destruction of the Wings was so complete that even the two major aviation museums in the United States don't have any:

. . And they were destroyed, each and every one of them. There is no example of the B-49 Flying Wing in the Air For ce Museum at Wright Patterson Air Force Base, nor is there an example in the Smithsonian Institution.

Of course there is no B-49 in the museums: only two were built and they both crashed. (The first prototype Flying Wing, the $N-1 M$, did survive and is now being restored by the Smithsonian; one of the three larger N-9M scale models still exists, and is being rebuilt by a museum in Chino, California. Neither of these was apparently deemed worthy of mention in the KCET documentary.) But is the fact that the full-sized Wings were not saved by the Air Force 
Museum significant?

We have seen earlier that at least seven aircraft types, including the RB-49, were cancelled by the senior officers Board in early 1949: North American's B-45 and F-93; Northrop's C-125 and RB-49; Consolidated's YT-32; Kellett's H-10; and Boeing's B/RB-54. 9 of those aircraft, only one was already operational--the B-45-- and it is the only one on display in the Air Force Museum today. All the rest were cancelled before going to their using commands; none of them is represented at the Museum. 10 Thus, the fact that no Flying wing is in the Air Force Museum cannot be construed as a sign of the Air Force's vindictiveness. The current director explained to the author in 1981 that the Museum emphasis has always been on operational Air Force aircraft, rather than on unique and interesting evolutionary cul-de-sacs; as he bluntly put it, "We're not running a freak show here." 11

\section{What the Decision-Makers knew}

In retrospect, with the advantage of $20 / 20$ hindsight, the decision to scrap the wings at the Northrop plant certainly appears regrettable. But before condemning those who issued the destruction orders, we must try to put ourselves in their position. Studies in August of 1948 had estimated the cost of the cheapest option--to simply "pickle" (i.e., preserve) and store the planes until their problems could be fixed--would be $\$ 2,500,000 .^{12}$ Further, to make the aircraft flyable would cost $\$ 7,500,000.13$ The decision- 
makers knew that the YB-49 was in flight test, and that the YRB-49 assembly and flight test would continue. With this information, we can see that the decision to scrap the airplanes was not vindictive or malevolent: if the Air Force leaders really wanted to destroy the Flying Wings, wouldn't they have destroyed the YB-49 at Edwards and the YRB-49 at Hawthorne? Would they have allowed the YB-49's subsequent appearance at a 1949 Washington air show? And would they have allowed the YRB-49 to be completed and entered into a new flight test program in 1950? Should we blame the 1949 decision-makers for the 1950 crash of the remaining YB-49, and for the 1953 destruction of the abandoned YRB-49?

The answers to these questions are obvious, and the conclusion to be drawn is obvious as well: the decision to destroy the Flying Wings at the Northrop plant appears tragic, viewed from our perspective thirty-five years later. But when we analyze the decision from a 1949 vantage point, it becomes clear that the chosen course of action was the logical and cost-effective one at the time.

\section{A Suitable Replacement for the B-29?}

In describing the Flying wing in the opening minutes of the KCET broadcast, Mr. Roberts stated:

[The YB-49] was the product of the genius of John $K$. Northrop and his crew of engineers, who had brought it to a point of development where it had been selected by the United States Air Force as the next generation bomber, the replacement for the 14 B-29 which had carried the air war against Japan. 
My research yielded not one bit of evidence that would support this statement. We have seen General Arnold's testimony, in which he explained how the ten-thousand-poundpayload/ten-thousand-mile-range airplane was the logical successor to the $\mathrm{B}-29$. And it is true that the $\mathrm{xB}-35$ and XB-36 were ordered with the expectation (or at least the hope) that at least one of them would prove a suitable successor to the B-29. But we have also seen that the $\mathrm{XB}-35$ was a near-total failure, primarily due to the ill-conceived propulsion system.

With the failure of the $\mathrm{xB}-35$, the future of the Flying wing bomber rested on the jet-powered conversion, the much shorter-ranged YB-49. But we have seen that, like its propeller-driven predecessor, the YB-49 suffered from its share of problems. Those problems have been detailed in earlier parts of this dissertation, but the bottom line deserves to be repeated: never was the YB-49 judged by the Air Force to be a suitable bomber, and never was it "selected by the United States Air Force as the next generation bomber, the replacement for the B-29."

\section{A "Flyoff" Against the B-36?}

Also misrepresented in the KCET show was the idea that there was a head-to-head competition between the YB-49 and Convair's B-36. In Mr. Roberts' words:

[The YB-49] flew in competition with these aircraft, the $\mathrm{B}-36 \mathrm{~s}$, and it won the flyoff. 
Such a "flyoff" connotes a situation similar to the 1970 's "fly before you buy" concept, in which multiple manufacturers built aircraft to the same set of specifications, and then the competitive prototypes were flown on identical missions to see which performed best. ${ }^{16}$ But no such situation existed with the B-36 and the YB-49: performance characteristics were completely different, the main discrepancies being in range and bomb capacity. The B-36 was classed by SAC as a "heavy" bomber $;^{17}$ the YB-49 was a "medium" bomber. ${ }^{18}$ We have seen the B-36 had a range approaching ten thousand miles; the YB-49 range was about half of that. We have seen also that the B-36 could carry 84,000 pounds of bombs; the YB-49 couldn't come close to that amount.

There was, of course, a kind of competition between the $\mathrm{B}-36$ and the Flying Wings, but it was based solely on budgetary, not performance-related, considerations. In much the same way that today's B-1 competes against the M-X missile for scarce dollars, so the B-49 series competed against the B-36; every dollar spent on the B-36 was a dollar unavailable for spending on the B-49 and other airplanes. But to claim that the YB-49 "won the flyoff" against the B-36 suggests that both aircraft were capable of performing the Strategic Air Command's mission and that the YB-49 was simply judged to be better. Such a suggestion is totally without foundation. 


\section{Conclusion}

There are other inaccuracies in "The Flying Wing-What Happened to It?", less significant than the ones detailed above. But what emerges from an analysis of the show's errors is perhaps more disconcerting than the errors themselves. There are so many mistakes, so many omissions, so many misleading statements, that the analyst is obliged to ask: Just what was the purpose of the KCET broadcast? Was it a good-faith effort to allow an old and dying man to express the beliefs he had held secretly for thirty-five years? Was it an attempt to ruin the reputation of a longtime public servant? or was it something in between: an effort, perhaps, to stir up a dormant controversy, in the hope that the truth would finally emerge?

Whatever the purpose, it should be noted that the show had the effect of severely, and unjustifiably, damaging the reputation of Stuart symington. In a 1983 interview, he expressed to the author his belief that the main thing he had to leave behind him was his reputation, and that that reputation had been unfairly and perhaps irretrievably damaged by the KCET broadcast. ${ }^{19}$ 


\section{Chapter IX Footnotes}

1"The Flying Wing--What Happened to It?"
${ }^{2}$ Ibid.

${ }^{3}$ Senator Symington telephone interview, November 17 , 1982. He gave a similar account to Mr. Walter Boyne, Acting Director of the National Air and Space Museum, in a letter dated November 4, 1982; copy to the author.

${ }^{4}$ Senator Symington interview, June 6, 1983.

5 "The Flying Wing--What Happened to It?"

${ }^{6}$ Ibid.

7 Director of Research and Development, Air Materiel Command to Major General E.M. Powers, Assistant Deputy Chief of Staff/Materiel; Confidential memo; February 25, 1949.

8 "The Flying Wing--What Happened to It?"

${ }^{9}$ Lt. General Edwin W. Rawlings, testimony before House Armed Services Committee, Investigation of the B-36 Bomber Program, pp. 456-457.

10 United States Air Force Museum (Wright Patterson AFB, Ohio: Air Force Museum Foundation, Inc., [1979]).

${ }^{11}$ Col. Richard L. Uppstrom, private conversation, 1981. The Air Force's interest in preserving one of a kind aircraft was astonishingly low after World war II, and bombers were especially ignored. Boeing's $\mathrm{XB}-15$ was the biggest aircraft ever built in this country when it was unveiled in 1938. Only one was manufactured; it was "disassembled" in 1945. Douglas' gigantic XB-19 was so heavy it broke through the pavement at most airfields, and featured a number of aviation firsts when it made its maiden flight in 1941. Like the XB-15, only one was built: it was scrapped at about the same time as the Flying Wings, in 1949. See Lloyd S. Jones, U.S. Bombers, B1-B70 (Los Angeles: Aero Publishers, 1962), pp. 36-38, 55-58.

12 Air Materiel Command Routing and Record sheet No. 1 , from YB-35/YB-49 Project office to Colonel Gerrity, Chief, Bombardment Branch; August 16, 1948 .

${ }^{13}$ see note 7 above.

14 "The Flying Wing--What Happened to It?" 


\section{${ }^{15}$ Ibid.}

16 The "Fly before you buy" concept never proved very fruitful for Northrop. Its A-9 attack aircraft lost out to Fairchild's A-10 in 1972 flight tests, while its YF-17 lightweight fighter was beaten by General Dynamics' (formerly Convair's) YF-16 in 1975. The YF-17 did go on, though, to become the U.S. Navy's F-18. See Anderson, Northrop: An Aeronautical History, pp. 250-256, 262-273.

${ }^{17}$ Development of the Strategic Air Command, p. 12.

${ }^{18}$ Colonel J.T. Perkins, Acting Deputy, Requirements Division, to General Partridge, Director, Training and Requirements; memo; June 25, 1948.

${ }^{19}$ Senator symington interview, June 6, 1983. 
CHAPTER $\mathrm{X}$

\section{IMPLICATIONS FOR MANAGEMENT}

This dissertation finds its meaning on two levels. On the surface, it is a detailed case study of an important aircraft development program gone awry. As such, it has developed into a critique of the critics, and a defense of the decision-makers who ended the Flying Wing program thirty-five years ago.

The second level of meaning is deeper, more general, and ultimately more important. No matter how fascinating a case study may be, it must ultimately derive its meaning from its predictive ability, that is, how well the study allows us to project its lessons into the future. By knowing the lessons of the past, we can best put ourselves in position to avoid their repetition.

Following, then, are some of the long-term lessons that can be learned from the demise of the Flying Wings.

\section{Importance of Marketing: Focus on the Customer}

In his 1960 article, "The Marketing Revolution", Robert $\mathrm{J}$. Keith discussed the primacy of the customer: The consumer, not the company, is in the middle. In today's economy the consumer, the man or woman who buys the product, is at the absolute dead center of the business universe. Companies reyolve around the customer, not the other way around. 
Mr. Keith went on to discuss what he saw as the four eras that characterized the "marketing revolution" at his firm, the Pillsbury Company. The first era was productionoriented, and consisted of the company's efforts to produce those goods it could fabricate well, and then to find a market in which to sell them. After evolving through a pair of intermediate stages, Mr. Keith said that, in 1960, his firm was on the brink of a fourth era, that of "marketing control." In this stage, the facets of marketing--research, product development, pricing, distribution, and the like-would dominate the firm. ${ }^{2}$

Other authors have since argued for the primacy of the customer, and thus of marketing. In his classic, Management: Tasks, Responsibilities, Practices, Peter Drucker emphasized that the most critical aspect of any business enterprise is not engineering, or technology, or a specific product. Rather, the focus of a business must be the customer, and the development and maintenance of that focus is the purpose of marketing:

There is only one valid definition of business purpose: to create a customer. . . Because its purpose is to create a customer, the business enterprise has two--and only these two--basic functions: marketing and innovation. . . Marketing is the distinguishing, unique function of the business. A zations bुy the fact that it markets a product or a service.

Mr. Drucker went on to emphasize that being a technological leader is never enough by itself: a successful firm must remain customer-oriented. His example is IBM, 
which used such a customer-orientation to leapfrog over the computer industry's technological pacesetters:

But while the technological leaders in the early computer days, Univac, GE, and RCA, were productfocused and technology-focused, the punch card salesmen who ran IBM asked: "Who is the customer? What is value for him? How does he buy? And, what
does he need?"

In today's marketing-oriented business world, such notions seem almost common-sense. But our review of the history of the Flying Wing program has revealed an almost complete lack of the "customer focus" that Mr. Keith and Mr. Drucker claimed to be so essential.

Northrop: A First-Era, Production-oriented Firm

It seems clear in retrospect that Northrop was totally oriented toward the product that it was uniquely capable of developing, and was, at the same time, little concerned about the needs of its customer. Even the genesis of the Flying Wing, as interpreted by pro-Northrop aviation author Bill Gunston, reflected the firm's focus on product:

of course, common sense shows that with small aircraft at least a rudimentary nacelle has to be retained in order for the occupant(s) to sit upright. . . For this and other reasons Northrop decided his first saleable flying wing would have to be very large. Indeed, it would have to be either 5 big civil transport or a long-range bomber.

Mr. Gunston went on to explain that the civil transport would definitely be harder to sell than the bomber: the airlines were too cautious to invest in such a radical and costly venture, but the Air corps had already proven to be something of an easy mark: 
In 1941, the answer was obvious. The transport would be much more difficult to do, there was no obvious customer with whom he could work and the marketing problem was clearly formidable. The airlines are conservative, and Northrop did not relish the penalty of building the right product ten years too soon. On the other hand.. . the Army, having poured out considerable funds for such giant bombers as the [Boeing] XB-15 and [Douglas] XB-19 without having any clear idea why, was rather eager

If Northrop paid little attention to the customer's needs at the outset, it paid even less as the project went along. We have seen that in every area that mattered to the customer, the Strategic Air Command, the Flying Wings were deficient. They could not carry the types and quantities of non-nuclear weapons necessary, and could not carry the early atomic bombs at all. Their ability to reach Eurasian targets was non-existent, since they had neither sufficient internal fuel capacity nor in-flight refueling capability. They were unable to deliver what bombs they could carry with the required accuracy, and their in-flight stability was, at best, doubtful.

In areas that did not matter much to $\mathrm{SAC}$, the Wings excelled. The YB/YRB-49s were fast, but speed without the range to reach the target was a useless strength. The Wings were maneuverable, able to outfly some of the top-performing fighters of that day. But this, too, was a characteristic not highly prized. General Kenney testified in 1949 that, as former SAC Commander, he didn't care about maneuverability "because a bomber doesn't maneuver in combat." 7 General Lemay also downplayed its significance: as he put it 
in a 1982 interview, if SAC bombers were called on to go to the Soviet Union, their aim would be to drop bombs, not engage the Russians in dog fights. Maneuverability did not matter to him at all. ${ }^{8}$

\section{"Marketing Myopia"}

How could a successful firm, led by such a brilliant aircraft designer, fail so badly in the arenas of management and marketing? The answer may lie in the fact that the very qualities that lead to success in technology and engineering can hamper performance in other critical areas. In his 1960 article, "Marketing Myopia", Theodore Levitt described just such a circumstance, in which engineering geniuses are baffled by the inconsistencies of the marketplace:

Having created a successful company by making a superior product, it is not surprising that management continues to be oriented toward the product rather than the people who consume it. . . . A number of other factors tend to strengthen and sustain this belief:

1. Because electronic products are highly complex and sophisticated, managements become top heavy with engineers and scientists. This creates a selective bias in favor of research and production at the expense of marketing. The organization tends to view itself as making things rather than satisfying customer needs. . .

2. To this bias... is added the bias in favor of dealing with controllable variables. Engineers and scientists are at home in the world of concrete things. . .

If Mr. Northrop developed a bias toward controllable variables, and one against the vagaries of the Air Force procurement process, he could hardly be blamed. The Air Force certainly contributed generously to the general misdirection which characterized the Flying wing's 
development. Mr. Levitt described the problems that custo-
mers cause:

Consumers are unpredictable, varied, fickle, stupid, short-sighted, stubborn, and generally bothersome. This is not what the engineer-managers say, but deep
down in their consciousness it is what they believe.

The Air Force was all that, and more. Consider just these examples we have already seen: first, the desired range for the $\mathrm{XB}-35$ five thousand miles, then--in a phone call--it was abruptly doubled to ten thousand. In May of 1948, Northrop got its order for thirty RB-49s; the very next month, production of twenty-nine of the thirty was shifted to a competitor; six months later, all thirty were cancelled. In 1946, General Kenney had tried to cancel the B-36; two years later, his successor gave up other aircraft, including Northrop's, to raise money for more B-36s. Add to these the problems caused by non-Air Force action--e.g., President Truman's FY 1950 budget cuts--and one can readily sympathize with the "engineer-manager's" point of view.

Nonetheless, the research/engineering/production bias certainly dominated Northrop's management of the Flying wing program. For nearly ten years, the underlying theme of the dialogue between Northrop and the Air Force is plain: the Air Force continually expressed concern about the practical features of the Wings--range, bomb carriage and delivery, in-flight stability, and production rates, to name just a few. The Northrop Aircraft Corporation's responses were equally consistent: it continued to ignore, or at least minimize, the Air Force's concerns, while trumpeting the 
Wing's successful aspects--speed, maneuverability, and aeronautical achievement. Unfortunately for Northrop those were facets which the customer, especially SAC and General LeMay, valued little or not at all.

\section{Marketing Planning}

The well-known marketing authority, Philip Kotler, has argued that effective marketing demands four major planning skills. 11 Two of them-- pricing and distribution-- did not play significant roles in the demise of the Flying Wings. The remaining two--product development and promotion--were central to the program's failure.

Product development--the need to develop an idea into a commodity that customers will pay for--has been covered extensively in other parts of this dissertation. The last factor, though--promotion--has not. If we define promotion as the need to reach a market and then to spur that market to a desired action (i.e., buy our product), we can see that some of Northop's actions in that area are hard to explain. Promotion presupposes, of course, that the firm knows what its market is, and that it stays in touch with that market through some form of feedback system. In 1949, Mr. Northrop testified that the RB-49 cancellation was "a shock. . . out of the blue." 12 But if he had been at all in touch with his market, he must have known the Flying wing was in trouble. The rapid improvement of the B-36 in late 1948 was well-documented in industry sources. ${ }^{13}$ The President's proposed budget cuts were also publicly reported, as was the 
replacement of General Kenney, no big fan of the B-36, by the pro-B-36 General LeMay. Even the existence of the Senior Officers Board, before which General LeMay testified, had been a poorly-kept secret in the industry. According to Aviation Week:

Aircraft manufacturers have been watching anxiously for indications of what a small group of top USAF generals have been up to for the past two weeks. Generals Norstad, McNarney, Craig, and Fairchild have been closeted in the Pentagon for top secret meetings during the ${ }_{4}$ holidays. The subject--aircraft procurement.

Given this, how the news of the cancellation could have come "out of the blue" to $\mathrm{Mr}$. Northrop is not clear. Rather, it would seem that a reasonably well-informed, marketing-oriented firm would have had at least some warning, perhaps enough time to try to reawaken the customer to the superior points of the Flying wing. But we will see that-for whatever reason--this did not occur.

\section{Promotion and Buyer Behavior}

In even the largest organizations, buying is still a function of individual behavior. It follows, then, that a firm must target its marketing efforts toward the individual decision-makers, not toward the monolithic organization. In their article, "A General Model for Understanding organizational Behavior", Frederick Webster, Jr. and Yoram Wind explained:

The individual is at the center of the buying process. . . It is the specific individual who is the target for the marketing effort, not the abstract organization. . . . It is important to understand the organizational buyer's psychological 
characteristics and especially his predispositions, preference structure, and decision modef $5^{\text {as }}$ the
basis for marketing strategy decisions.

So who was the individual at whom marketing efforts on behalf of the Flying Wing should have been aimed? Certainly not Mr. Symington: in addition to his claim that he let military people make such decisions, we also have seen that the decision-model for weapon system acquisition went from the bottom up, not from the top down. ${ }^{16}$

As General Norstad put it:

In no way did he [Mr. Symington] ever generate requirements. Those came $\operatorname{from}_{7} \mathrm{me}$, and they came to me from the using commands.

So we've seen that the using command, in this case SAC, determined aircraft requirements. It follows, then, that the using commander, General LeMay, should have been at least one of the major targets for Northrop's marketing effort. But in his 1949 appearance before the House Armed Services Committee, Mr. Northrop testified that he thought he had discussed the Flying Wing with General LeMay, but at least three years earlier, long before the General's assignment to SAC. ${ }^{18}$ This is a difficult situation to understand: in late 1948 and 1949, General LeMay held the key to an $\$ 84,000,000$ contract, and yet Mr. Northrop had not discussed it with him since 1946! When he took over the Strategic Air Command in October of 1948, might General LeMay have had contact with other members of Mr. Northrop's firm regarding the Flying Wing? Interviewed in 1982 , General LeMay recalled no discussions with Northrop people 
about the Flying Wings. In fact, he didn't even consider the Wings to be among the viable contenders, although thirty of the reconnaissance models were already on order; perhaps incredibly, General LeMay never once even saw the Flying Wings that Mr. Northrop wanted to see become the major component of America's strategic reconnaissance force:

I don't think [the B-49] was even in the running, [and] the -35 wasn't in the picture at all...'. No, I never even saw the things, just pictures over the years, that's all.

So, Northrop's marketing efforts apparently did not include discussing the product with the one man who had greatest control over its fate. Further, when he appeared before the Senior Officers Board to argue for more B-36s at the expense of the RB-49 order, General LeMay had no firsthand knowledge of the Northrop product.

Whether one places the responsibility for this lack of dialogue on the manufacturer or on the Air Force, the simple fact remains: the Flying wings had no support from that most critical quarter, the customer.

\section{$\underline{\text { Summary }}$}

To understand the failure of the Flying Wing, one should look not in the direction of political maneuvering or unethical behavior, but rather toward the more prosaic concepts of marketing. A marketing-oriented firm would have determined the needs of its customer, and then built a product to fulfill those needs; Northrop, being a technologically-oriented enterprise, instead developed a product 
based on its own unique capabilities, and then tried to find a customer for that already-determined product. When the customer protested over a period of nearly ten years that the product couldn't do the job that needed to be done, a marketing-oriented firm would have at least paid attention; Northrop pressed on, minimizing the importance of the flaws while touting the Flying Wing's far less significant strengths. A marketing-oriented firm would have known that in even the largest of organizations, buying decisions are ultimately made by individuals, and it would have made efforts to favorably influence those individuals; Northrop did not, perhaps believing that the innovative characteristics of the Flying Wing were enough to make, and keep, the sale. Finally, a marketing-oriented firm would have realized that a customer buys not so much a product as he buys utility: the B-36, for example, with its bulbous cockpit, ungainly fuselage, six pusher propellers and four tacked-on jets, hardly qualified as a major aesthetic breakthrough, but the customer didn't care. As General LeMay said, it could do the job at the time. Convair sold SAC not the B-36, but rather its capability and usefulness; Northrop sold only the Flying wing.

\section{Toward the Future}

Today, Northrop is again working on another Flying Wing: the highly classified "stealth bomber." 20 in other ways, though, the corporation is much different, and signs indicate that Northrop has learned much since the 
Flying Wing era of the 1940's. Management is perhaps less engineering-biased: the current chairman, an engineer by training, started with Northrop as a planner thirty years ago, after leaving the Rand Corporation; the current president is a manufacturing expert; his predecessor was a former administrator of the National Aeronautics and Space Administration. 21 In addition, areas that hampered the development of the old Flying Wings have been addressed: a 1982 plant acquisition and other improvements valued at $\$ 200$ million will avoid the capacity constraints that hurt the firm in the past, ${ }^{22}$ while advances in electronic flight controls are expected to negate the problems of instability which plagued the big bombers. The most important change, though, is Northrop's development of a marketing-orientation: the stealth bomber is being developed not only because Northrop knows how to build it, but also because the customer (once again the Air Force, specifically SAC) needs it.

\section{Conclusion}

In a 1978 article in the Journal of Marketing, Derek Abell introduced the concept of "strategic windows". He suggested that the best time to push a product is when such a "strategic window" is open, when there is a smooth meshing between the needs of the customer and the peculiar strengths of the producer:

The term "strategic window" is used here to focus periods of time during which the "fit" between
key requirements of a market and the particular 
competencies of $3_{3}$ a firm competing in that market is at an optimum.

clearly such a strategic window did not exist in the 1940 's, when both Northrop's still-developing technology and the Air Force's changing requirements combined to doom the Flying wing bombers. The situation today, though, promises to be different: the demands of the customer seem in harmony with the capabilities of the producer. Thirty-five years after the deaths of their graceful predecessors, the window to success for the Flying wings may at last be open. 


\section{Chapter X Footnotes}

${ }^{1}$ Robert $J$. Keith, "The Marketing Revolution," Journal of Marketing (January 1960): 35-38. Reprinted in Marketing Classics, 4 th ed., ed. Ben M. Enis and Keith M. Cox (Boston: Allyn and Bacon, 1981), p. 44.

${ }^{2}$ Ibid., pp. 44-49.

${ }^{3}$ Peter F. Drucker, Management: Tasks, Responsibilities, Practices (New York: Harper and Row,1973), pp. 61-62.

${ }^{4}$ Ibid., pp. 63-64.

${ }^{5}$ Bill Gunston, "The All-Wing Northrops," p. 482.

6 Ibid.

${ }^{7}$ Gen. George C. Kenney, testimony before the House Armed Services Committee, Investigation of the B-36 Bomber program, p. 131.

${ }^{8}$ Lemay interview.

9 Theodore Levitt, "Marketing Myopia," Harvard Business Review (July-August 1960). Reprinted in Enis and Cox, Marketing Classics, p. 16.

10 Ibid.

${ }^{11}$ Philip Kotler, "A Generic Concept of Marketing," Journal of Marketing (April 1972): 46-54. Reprinted in Enis and Cox, Marketing Classics, p. 71 .

12 John K. Northrop testimony, p. 270.

13 "New B-36 to Give USAF Greater Range," Aviation Week, October 18, 1948, pp. 12-14. This article described the jet-equipped $B-36 D$, and was just one of a whole series of references to the improving B-36 in late 1948 . 1949 , p. 7 .

14 "Industry Observer," Aviation Week, January 10,

15 Frederick E. Webster, Jr. and Yoram Wind, "A General Model for Understanding Buying Behavior," Journal of Marketing (April 1972): 12-19. Reprinted in Enis and Cox, Marketing Classics, p. 167. 
16 There is an oft-told tale concerning President Truman, who reportedly saw the Flying Wing at an airshow in 1949, and said, "Perhaps we should have some of these." General Cardenas, who flew the YB-49 to that airshow at Andrews Air Force Base, confirmed in his 1983 letter that he heard President Truman made the remark to a person General Cardenas could not identify. Senator symington, though, had no recollection of ever seeing the Flying Wing, at Andrews or anywhere else. In a telephone interview on November 17, 1982 he said:

I never had any discussion of the Flying wing with President Truman. I did go with him to an air show at Andrews, and we watched a flyover of $\mathrm{B}-36 \mathrm{~s}$, and saw one on the ground. I remember, too, the arrival of the brand new B-47--it was the first time any of us had seen a rear parachute. But I don't recall seeing the Flying Wing--there or anywhere else. I may have seen it, but I don't remember it.

Even though the President did make favorable comments about the YB-49, those remarks probably should be taken in a kind of "window shopping" context. The President was apparently impressed by the technology of the aircraft at the show, but appalled at the price tags. As Mr. Symington said in his 1949 testimony before the House Armed Services Committee, the President was "hot on the airplanes, cold on the cost." See Mr. Symington testimony, p. 226.

17 General Norstad telephone interview.

${ }^{18}$ John K. Northrop testimony, p. 270.

${ }^{19}$ General Lemay interview.

20 For a good discussion of Northrop in the 1980's and for one of the best unclassified descriptions of the ultrasecret "stealth bomber", see "Look Who's Heading for No. 1 in Defense: Northrop," Business Week, April 19, 1982; pp.7079 .

\section{${ }^{21}$ Ibid., pp. 75-77. \\ 22 Ibid. , pp. $71,73$.}

23 Derek F. Abell, "Strategic Windows," Journal of Marketing (July 1978): $21-26$. Reprinted in Readings in Basic
Marketing, 3d ed., E. Jerome McCarthy et. al. (Homewood, Illinois: Richard D. Irwin, Inc., 1981), p. 164. 


\section{BIBLIOGRAPHY}

\section{Books}

Anderson, Fred. Northrop: An Aeronautical History. Los Angeles: Northrop Corporation, 1976.

Borowski, Harry R. A Hollow Threat: Strategic Air Power and Containment before Korea. Westport, Connecticut: Greenwood Press, 1982 .

Boyne, Walter J. Messerschmitt ME-262: Arrow to the Future. Washington, D.C.: Smithsonian Institution Press, 1980.

Bradley, General Omar N. and Blair, Clay. A General's Life: An Autobiography by General of the Army Omar N. Bradley. New York: Simon and Schuster, 1983.

Drucker, Peter F. Management: Tasks, Responsibilities, Practices. New York: Harper and Row, 1973.

Enis, Ben M. and Cox, Keith K., ed. Marketing Classics: A Selection of Influential Articles, 4th ed. Boston: Allyn and Bacon, 1981 .

Jacobsen, Meyers $\mathrm{K}$. and Wagner, Ray. B-36 in Action. Carrollton, Texas: Squadron/Signal Publications, 1980.

Johnsen, Frederick A. Thundering Peacemaker. Tacoma, Washington: Bomber Books, 1978 .

Jones, Lloyd S. U.S. Bombers: B1-B70. Los Angeles: Aero Publishers, 1962 .

Kotler, Philip. Marketing Management: Analysis, Planning, and Control, $4 \mathrm{th}$ ed. Englewood Cliffs, N.J.: Prentice Hall, 1980 .

LeMay, General Curtis E. with Kantor, Mackinlay. Mission With LeMay. Garden City, New York: Doubleday and Company, 1965 .

McCarthy, E. Jerome; Grashof, John F.; and Brogowicz, Andrew ic Marketing. Homewood, Illinois: Richard D. Irwin, 1981.

Maloney, Edward T. Northrop Flying Wings. Corona del Mar, California: World War II Publications, 1980. 
Millis, Walter, ed. The Forrestal Diaries. New York: Mac-
millan, 1951. Northrop Aircraft, Inc. Pilot's Handbook for the Model YB-49 Appleton, Wisconsin: Aviation Publications, 1977.

Puryear, Edgar F., Jr. Stars in Flight: A Study in Air Force Character and Leadership. Novato, California: Presidio Press, 1981.

Rae, John B. Climb to Greatness: The American Aircraft Industry, 1920-1960. Cambridge, Massachusetts: The MIT Press, 1968 .

Rogow, Arnold A. James Forrestal: A Study of Personality, Politics, and Policy. New York: Macmillan, 1963.

Strategic Air Command, Office of the Historian. Development of the Strategic Air Command, 1946-1976. Offutt Air Force Base, Nebraska, 1976.

Truman, President Harry S. Memoirs by Harry S. Truman, Volume Two: Years of Trial and Hope. Garden City, New York: Doubleday and Co., 1956.

Newspapers, Journals, and Magazines

"Aircraft Manufacturer Mergers." Aviation Week; January 17 , 1949 ; p. 18 .

"Air Force Confirms YB-49 Record." Aviation Week; November 8,$1948 ;$ p. 14 .

"Air Force to Boost B-49 Orders." Aviation Week; August 2, 1948 ; pp. 11-12.

"Airline Wing?" Aviation Week; November 15, 1948; p. 18.

"Air Refueling: Key to Long Range." Aviation Week; January 17,$1949 ;$ p. 15 .

"Briefing Production News." Aviation Week; October 8, 1948; p. 18 .

"Crash of Capt Glen Edwards 26 Years Ago Recalls Era of Giant Northrop Flying Wing." Daily Ledger Gazette; June 7, $1974 ;$ p. 5 .

"Cutbacks Make Way for New B-36 orders." Aviation Week; January 17,$1949 ;$ p. 18 . 
"Edwards Flying Wing Crash 25 Years Ago." Antelope Valley
Press; June 5, 1973; pp. 1-2. "Fight for 70-Group Air Force Flares Again on Capitol Hill."
Aviation Week; April 5, 1948; p.11.

"Flying the Wing." Northrop News; July 10, 1981; p. 5.

"Flying Wing Jet Bomber Completed." Aviation Week; October
13, 1947; p. 14. "Forrestal Warns of Schedule Lag." Aviation Week; January
10, 1949; p. 13.

"Industry Observer." Aviation Week; May 17, 1948; p. 14.

- Aviation Week; May 24, 1948; p. 15.

- Aviation Week; May 31,$1948 ;$ p. 16.

- Aviation Week; September 20, 1948; p. 7.

- Aviation Week; January 10, 1949; p. 11.

- Aviation Week; April 25, 1949; p. 9.

"Industry Regains Health and Productivity." Aviation Week; February 28, 1949; p. 20.

"Instability May Spur Mergers." Aviation Week; January 31, 1949 ; p. 29 .

"Jet Wing Crash." Aviation Week; June 14, 1948; p. 12.

"Jet Wing Flies." Aviation Week; October 27, 1947; p. 14.

"Kill the B-36 Rumors." Aviation Week; March 21, 1949; p. 82 .

"Look Who's Heading for No. 1 in Defense: Northrop." Business Week; April 19, 1982; pp. 70-79.

"Low Drag Accentuated in All-Wing." Aviation Week; December 20,1948 ; p. 21.

"Merger Still Cooking." Aviation Week; September 27, 1948; p. 7.

"Merit Awards." Aviation Week; December 13, 1948; p. 14.

"New B-36 to Give USAF Greater Range." Aviation Week; October 18, 1948; pp. 12-14.

"New Orders." Aviation Week; December 27, 1948; p. 16. 

"New Stealth Bomber Shapes Up as an Advanced 'Flying Wing'."
Washington Post; May 5, 1982; p. 2 .

"Northrop Claims AF Scuttled 'Flying Wing'." Los Angeles
Times; December 8, 1980. "Northrop, Convair Trends Conflict." Aviation Week; November
1, 1948; p. 30. "Northrop Shows Profit of $\$ 240,573$ For Year." Aviation Week;
October 20, 1947; p. 14.

"Plane Order Shifts Involve $\$ 500$ Million." Aviation Week; January 24,1949 ; pp. 11-13.

"Procurement Board." Aviation Week; January 10, 1949; p. 7.

"The All-Wing Northrops." Bill Gunston in Aeroplane Monthly; January 1974; pp. 442-449.

- Bill Gunston in Aeroplane Monthly; February 1974; pp. $482-489$.

"United States Air Force Emerges From New Defense Organization." Aviation Week; September 29, 1947, p. 9.

"USAF Will Buy 23 Pioneers." Aviation Week; March 8, 1948; p. 16 .

"What the Budget Means to Procurement." Aviation Week; January 17, 1949; pp. 12-13.

"World's Most Powerful Plane Takes to Air For First Time." Los Angeles Times; October 22, 1947; pp. 1,3.

"XB-47 in New Speed Conquests." Aviation Week; February 14, 1949 ; p. 13 .

"YB-49 Heads For Muroc and Army Flight Tests." Aviation Week; November 3, 1947; p. 13.

\section{Government Documents}

Air Materiel Command Historical Office, Executive Secretariat. Case History of B-36 Airplane; May 28, 1948.

- Case History of XB-35 Airplane Project. No date, but apparently between 1946 and 1949 . 
- Case History of XB-35, YB-49 Airplanes (Supplement As with the above references airplane); February history" is misleading: the document the term "case collections of pertinent letters, affecting the programs over the years.

Maxwell Air Force Base, Alabama. Alfred F. Simpson Historical Research Center. General George C. Kenney Papers.

Maxwell Air Force Base, Alabama. Alfred F. Simpson Historical Research Center. XB-35, YB-49 Document File. Microfilm Index A2061.

U.S. Congress. House. Committee on Armed Services. Hearings before the Committee on Armed Services on H.R. 234, Investigations Relating to Matters Involving the B-36 Bombers. 81st Cong., 1st Sess., 1949.

\section{Letters}

Boyne, Walter J., Acting Director, National Air and Space Museum, to Senator Stuart Symington, October 25, 1982.

Cardenas, Brigadier General Robert L., to the author. Undated, 1983.

Schleeh, Colonel R.E., to the author. September 24, 1981.

Schleeh, Colonel R.E., to E.T. Wooldridge, National Air and Space Museum, November 24, 1982. Copy to the author, January 19, 1983.

Symington, Senator Stuart, to Walter J. Boyne, National Air and Space Museum, November 4, 1982. Copy to the author, November $17,1982$.

, to Walter J. Boyne, National Air and Space Museum, January 7, 1983. Copy to the author, January 10, 1983.

, to the author, May 4, 1983.

, to the author, May 20, 1983.

, to the author, May 25, 1983.

, to the author, June 10, 1983.

, to the author, June 29, 1983. 


\section{Interviews}

Jones, Thomas V. Telephone interview from Los Angeles,
California; November 4, 1983 .

Lemay, General Curtis E. Newport Beach, California. Inter-
view, September 29, 1982.

Norstad, General Lauris 0. Telephone interview from Tubac,
Arizona; January 31, 1983 Quesada, General Elwood P. U.S. Air Force Academy, Colorado.
Interview, April 7, 1983.

Schleeh, Colonel R.E. Telephone interview from Long Beach, California; July 20, 1983.

Symington, Senator Stuart. Telephone interview from Washington, D.C.; November 17, 1982.

- New Canaan, Connecticut. Interview, June 6, 1983.

\section{Miscellaneous Sources}

Baker, Francis J. "A History of Air Refueling." Fifteenth Air Force Headquarters, Strategic Air Command, 1980.

Green, Murray. "Stuart Symington and the B-36." Ph.D. dissertation, American University, 1960.

Northrop Aircraft, Inc. "Facts About Flying Wings: A Primer on All-Wing Aircraft." Undated.

Northrop Aircraft, Inc. "The Story of Jack Northrop and The Flying Wings." Press release, undated.

Northrop, John K. "The Development of All-Wing Aircraft." Paper presented as the 35th Wilbur Wright Memorial Lecture to the Royal Aeronautical Society; May 29, 1947.

Roberts, Clete. "The Flying Wing--What Happened to It?" KCET-TV, December 3, 1980.

Sears, W.R. "Flying Wing Airplanes: The XB-35/YB-49 Program." Paper presented to a conference on "The Evolution of Aircraft Wing Design," Dayton, Ohio; March 1819,1980 .

Stanley, Max. "The Flying Wings." Paper presented to the 24 th Symposium of the Society of Experimental Test Pilots, Beverly Hills, California; September 24-27, 1980 . 